\title{
Mobility Statistics and Automated Hazard Mapping for Debris Flows and Rock Avalanches
}

Scientific Investigations Report 2007-5276

Version 1.1 



\section{Mobility Statistics and Automated Hazard Mapping for Debris Flows and Rock Avalanches}

By Julia P. Griswold and Richard M. Iverson

Scientific Investigations Report 2007-5276

Version 1.1 


\title{
U.S. Department of the Interior DIRK KEMPTHORNE, Secretary
}

\section{U.S. Geological Survey Mark D. Myers, Director}

\author{
U.S. Geological Survey, Reston, Virginia: 2008 \\ Revised 2014
}

This report and any updates to it are available at:

http://pubs.usgs.gov/sir/2007/5276/

For product and ordering information:

World Wide Web: http://www.usgs.gov/pubprod

Telephone: 1-888-ASK-USGS

For more information on the USGS--the Federal source for science about the Earth, its natural and living resources,

natural hazards, and the environment:

World Wide Web: http://www.usgs.gov

Telephone: 1-888-ASK-USGS

Any use of trade, product, or firm names is for descriptive purposes only and does not imply endorsement by the

U.S. Government.

Although this report is in the public domain, permission must be secured from the individual copyright owners to reproduce any copyrighted materials contained within this report.

Suggested citation:

Griswold, J.P., and Iverson, R.M., 2008, Mobility statistics and automated hazard mapping for debris flows and rock avalanches (ver. 1.1, April 2014): U.S. Geological Survey Scientific Investigations Report 2007-5276, 59 p.

Manuscript approved for publication, December 12, 2007

Text edited by Tracey L. Suzuki

Layout by Luis E. Menoyo 


\section{Contents}

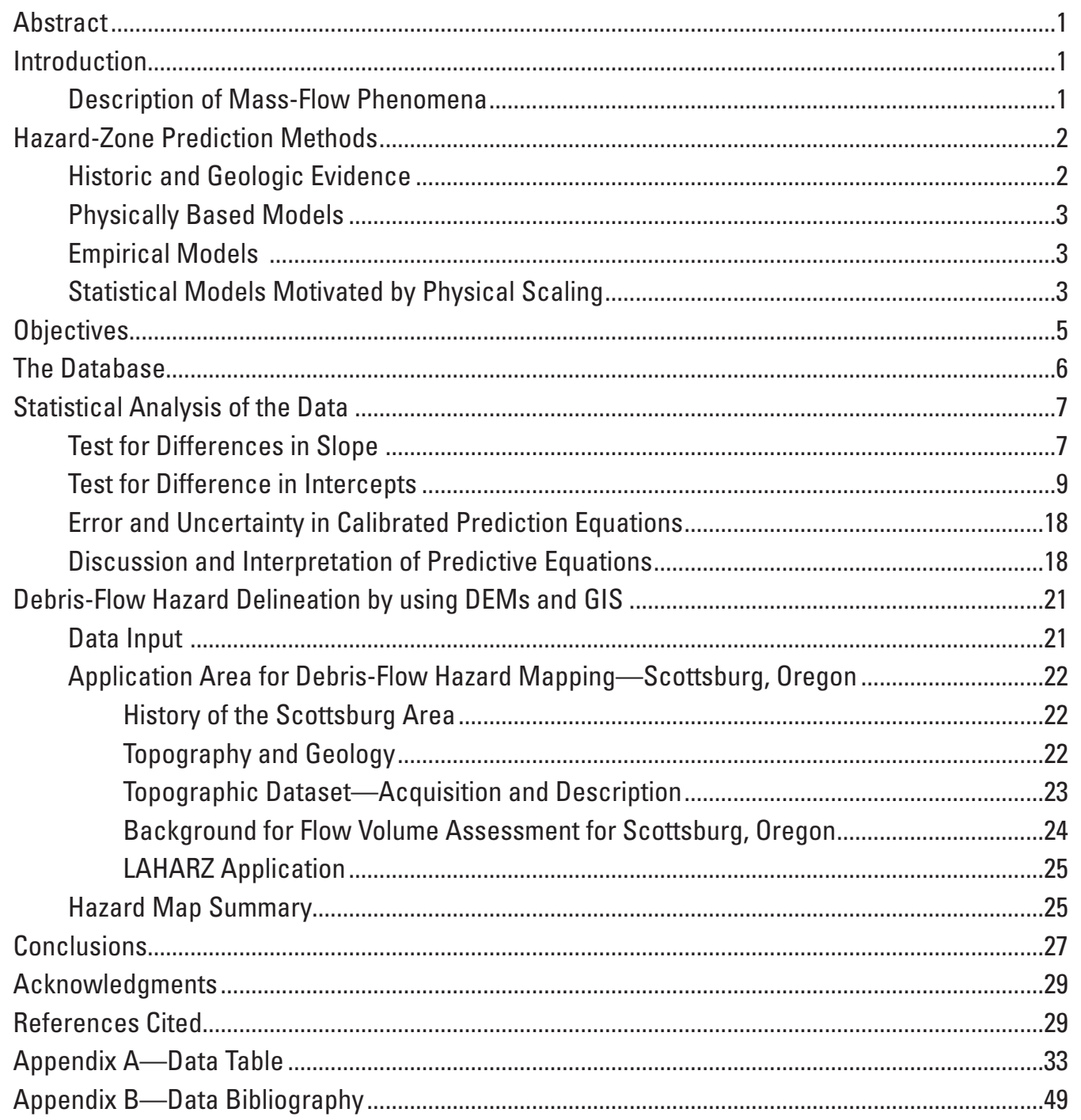

\section{Figures}

1. Schematic inundation limits of a debris flow moving down-valley from a source area.

2. Diagram showing the maximum inundated cross-sectional area, and total inundated planimetric area, of a lahar runout path downstream from a source area on a volcano

3. Scatter plot of all data compiled for debris flows, rock avalanches, and lahars ..............8

4. Debris-flow data and three regression models for cross-sectional area ........................10

5. Debris-flow data and three regression models for planimetric area ...............................10 


\section{Figures-Continued}

6. Rock-avalanche data and three regression models for cross-sectional area ................10

7. Rock-avalanche data and three regression models for planimetric area .......................10

8. Rock-avalanche and lahar data used to compute statistics as a combined dataset.....17

9. Debris-flow and lahar data used to compute statistics as a combined dataset .............17

10. Debris-flow and rock-avalanche data used to compute statistics as a combined dataset

11. Lahar data and best-fit regression line with 99-percent confidence interval for regression and 99-percent confidence interval for prediction after Iverson and others

12. Debris-flow data and best-fit regression line with 99-percent confidence interval for regression and 99-percent confidence interval for prediction.

13. Rock-avalanche data and best-fit regression line with 99-percent confidence interval for regression and 99-percent confidence interval for prediction .....................20

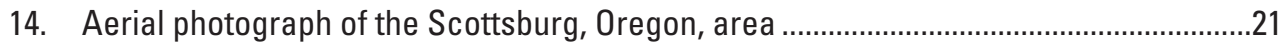

15. Shaded-relief map with highways and logging roads for the study area west of the town of Scottsburg in the central Coast Range of Oregon, at about 40 river kilometers from the coast..

16. Shaded relief map constructed from a DEM, overlaid with orange where slopes

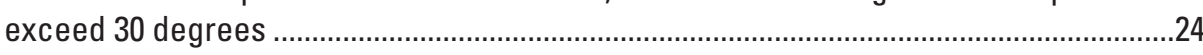

17. Shaded relief map of upper half of the test basin ........................................................25

18. Examples of nested, inundation-hazard zones computed for four flow volumes ............26

19. Debris-flow inundation-hazard map computed for four flow volumes ranging from $10^{3}$ to $10^{4.5} \mathrm{~m}^{3}$

20. Oblique perspectives of the test basin with debris flow-hazard zone overlays, view to the southeast

\section{Tables}

1. Parameters and analysis-of-variance statistics for alternative linear models of log-transformed debris-flow data for inundated cross-sectional area, as a function of flow volume

2. Parameters and analysis-of-variance statistics for alternative linear models of log-transformed debris-flow data for inundated-planimetric area, as a function of flow volume

3. Parameters and analysis-of-variance statistics for alternative linear models of log-transformed rock-avalanche data for inundated cross-sectional area, as a function of flow volume

4. Parameters and analysis-of-variance statistics for alternative linear models of log-transformed rock-avalanche data for inundated-planimetric area, as a function of flow volume

5. Summary table of the best-fit regression equations with calibrated slopes and intercepts 


\section{Tables-Continued}

6. Summary table of the best-fit regression equations with specified $2 / 3$ slopes and

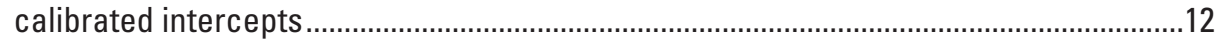

7. Summary of results of F-tests comparing the specified-slope models to the best-fit regression model with adjustable slope ...........................................................13

8. Dummy variable terms and equations for null model and alternate models ....................14

9. Parameters for computing the F-statistic to compare the specified 2/3-slope models with combined and individual datasets ..............................................................14

10. Parameters for computing the F-statistic to compare the best-fit regression models with combined and individual datasets ............................................................14

11. F-test comparison between the combined dataset and individual datasets for rock avalanches and lahars................................................................................. 15

12. F-test comparison between the combined dataset and the individual datasets for debris flows and lahars ....................................................................................... 15

13. F-test comparison between the combined dataset and the individual datasets for

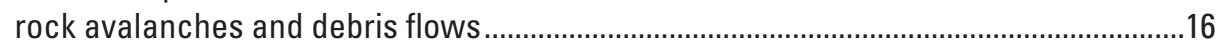

14. F-test comparison between combined rock avalanche and lahar datasets and the listed individual datasets for a best-fit regression slope ................................................16

15. F-test comparison between combined debris flow and lahar datasets and the listed individual datasets for a best-fit regression slope. . .16

16. F-test comparison between combined rock avalanche and debris flow datasets and the listed individual datasets for a best-fit regression slope 


\title{
Mobility Statistics and Automated Hazard Mapping for Debris Flows and Rock Avalanches
}

\author{
By Julia P. Griswold and Richard M. Iverson
}

\section{Abstract}

Power-law equations that are physically motivated and statistically tested and calibrated provide a basis for forecasting areas likely to be inundated by debris flows, rock avalanches, and lahars with diverse volumes. The equations $A=\alpha_{1} V^{2 / 3}$ and $B=\alpha_{2} V^{2 / 3}$ are based on the postulate that the maximum valley cross-sectional area $(A)$ and total valley planimetric area $(B)$ likely to be inundated by a flow depend only on its volume $(V)$ and the topography of the flow path. Testing of these equations involves determining whether or not they fit data for documented flows satisfactorily, and calibration entails determining best-fit values of the coefficients $\alpha_{1}$ and $\alpha$, for debris flows, rock avalanches, and lahars. This report describes statistical testing and calibration of the equations by using field data compiled from many sources, and it describes application of the equations to delineation of debris-flow hazard zones.

Statistical results show that for each type of flow (debris flows, rock avalanches, and lahars), the dependence of $A$ and $B$ on $V$ is described well by power laws with exponents equal to $2 / 3$. This value of the exponent produces fits that are effectively indistinguishable from the best fits obtained by using adjustable power-law exponents. Statistically calibrated values of the coefficients $\alpha_{1}$ and $\alpha_{2}$ provide scale-invariant indices of the relative mobilities of rock avalanches $\left(\alpha_{1}=0.2, \alpha_{2}=20\right)$, nonvolcanic debris flows $\left(\alpha_{1}=0.1, \alpha_{2}=20\right)$, and lahars $\left(\alpha_{1}=0.05, \alpha_{2}=200\right)$. These values show, for example, that a lahar of specified volume can be expected to inundate a planimetric area ten times larger than that inundated by a rock avalanche or nonvolcanic debris flow of the same volume.

The utility of the calibrated debris-flow inundation equations $A=0.1 \mathrm{~V}^{2 / 3}$ and $B=20 \mathrm{~V}^{2 / 3}$ is demonstrated by using them within the GIS program LAHARZ to delineate nested hazard zones for future debris flows in an area bordering the Umpqua River in the south-central Oregon Coast Range. This application requires use of high-resolution topographic data derived form LIDAR surveys, knowledge of local geology to specify a suitable range of prospective debris-flow volumes, and development and use of a new algorithm for identification of prospective debris-flow source areas in finely dissected terrain.

\section{Introduction}

Debris flows and rock avalanches are two types of rapid mass movement that can pose great hazards to areas downslope and downstream. This report presents a methodology to assess areas likely to be affected by downslope and downstream runout of debris flows and rock avalanches by deriving and employing inundation-area statistics, analogous to an approach used by Iverson and others (1998) for lahars. Establishing inundation-area relationships for differing types of flows aids in understanding flow mobility and enables delineation of hazard zones that may be inundated by future lahars, nonvolcanic debris flows, and rock avalanches.

The lahar-inundation equations developed by Iverson and others (1998) are currently used to compute hazard zones in areas adjacent to volcanoes around the Pacific Rim. Schilling (1998) implemented the set of lahar-inundation equations in LAHARZ, a Geographic Information System (GIS)-based computer program that facilitates rapid calculation and delineation of the hazard zones for a range of probable flow volumes and any flow-path topography represented by a digital elevation model (DEM). This study expands the use of LAHARZ with modifications for hazard mapping of nonvolcanic debris flows and rock avalanches.

\section{Description of Mass-Flow Phenomena}

Rapid mass flows on Earth's surface include the following related phenomena: dry, granular-rock avalanches, water-saturated debris flows, and hyperconcentrated stream flows (for example, Pierson and Costa, 1987; Iverson and Vallance, 2001). Flows are described by many terms in common practice and in the scientific literature, but our nomenclature is restricted to rock avalanche, debris flow (nonvolcanic), and lahar (volcanic debris flow). In this section, we discuss the general nature of these flows.

Rock avalanches commonly initiate as rock-slab failures or rockfalls and transform into unsaturated, granular flows. Rockfalls result from failure along a bedrock discontinuity (fracture, bedding, foliation), or from failure of a pocket of rubble perched in a bedrock face. Their motion is influenced 
by gravity, intergranular vibrational energy, and Coulomb friction (Iverson, 2003). Rock avalanches tumble from mountainsides and commonly travel to distal areas where they terminate on flatter slopes. Deposits may include massive hummocks composed of coarse debris and partially saturated sediment (Crandell, 1989). Although small rock avalanches occur commonly, they are seldom well documented, and volumes of well-documented rock avalanches generally exceed $10^{6} \mathrm{~m}^{3}$ (cubic meters). At Mount Shasta in California, the deposit of one prehistoric rock avalanche is estimated to have a volume $\sim 45 \mathrm{~km}^{3}\left(>10^{10} \mathrm{~m}^{3}\right.$; Crandell, 1989). The large volume of some rock avalanches can result in burial and filling of entire valleys, potentially damming rivers and creating breeching hazards for some time after the initial event. Additional descriptions and reports on rock avalanches are provided by Voight (1979), Eisbacher and Clague (1984), Ui and others (1986), Siebert (1984), Ui (1983), and Siebert and others (1987).

Debris flows differ from rock avalanches primarily because of their high water content and resulting fluidity; they typically initiate in steep drainages (generally sloping

$>30^{\circ}$ ) where sufficient unconsolidated sediment and water are available. The water-saturated sediment liquefies during initial slope failure or subsequent entrainment and stays fluid due to the persistence of high pore-fluid pressure, which is facilitated by the presence of fine matrix sediment (Iverson and others, 1997). Steep slopes, the presence of shallow soils, colluvium, alluvium, or poorly consolidated bedrock, and the presence of abundant surface water (for example, ponded water, snow, ice, runoff, outbreak flood) or shallow ground water (perched or return flow) provide conditions that favor development of debris flows. Local topographic features commonly play a role in focusing water flow on slopes where failure occurs. These topographic features include gullies, swales, hollows, or convergent slopes and also can include constructed features such as road-fill prisms. Focusing of shallow ground water also is influenced by stratigraphy that may aid saturation and development of high pore-water pressures (for example, Reid and Iverson, 1992). Termination of debris-flow motion downvalley on lesser slopes of stream channels, alluvial fans, or other gently sloping areas commonly results in a coarse depositional snout and bounding levees that enclose a liquefied interior of finer material (Iverson, 1997). Volumes of nonvolcanic debris flows rarely exceed $10^{6} \mathrm{~m}^{3}$, and although debris flows are commonly smaller than rock avalanches, they occur frequently and are responsible for similar numbers of deaths as reported in Schuster's (1996) list of "The 25 most catastrophic landslides of the 20th century". Additional descriptions and reports about debris flows are provided by Jakob and Hungr (2005), Iverson (1997), Iverson and others (1997), Major (1996), Fannin and Rollerson (1993), Takahashi (1991), and Johnson (1984).

Lahars are debris flows that originate on the flanks of volcanoes where abundant, loose sediment is available, and they may be triggered by volcanic eruptions, earthquakes, glacier or lake break-out floods, or torrential rains (Myers and Brantley, 1995). Hydrothermal alteration and (or) a high degree of fragmentation of volcanic rubble makes for a readily erodible and commonly clay-rich source material (Vallance and Scott, 1997). The failed volcanic material can incorporate large volumes of water, ice, and snow to reach full saturation. Lahars generally inundate the lower flanks of volcanoes, as well as downstream reaches of streams that originate on those flanks. Volumes of well-documented lahars generally exceed those of nonvolcanic debris flows and are typically $>10^{5} \mathrm{~m}^{3}$. Observed runout distances of lahars indicate they are typically more mobile than rock avalanches. For example, large lahars originating on Mount Rainier have traveled more than $120 \mathrm{~km}$ to Puget Sound, filling the White River Valley to depths greater than $100 \mathrm{~m}$ (Vallance and Scott, 1997). Additional descriptions and reports about lahars are provided by Crandell and Mullineaux (1967, 1975), Janda and others (1981), Major (1984), and Pierson (1985).

\section{Hazard-Zone Prediction Methods}

Numerous methods have been proposed to predict areas likely to be inundated by future granular mass flows. These methods include (1) use of historic and geologic evidence of past flows to estimate inundation limits of future flows, (2) use of physically based models that invoke conservation of mass, momentum, and energy and rheological properties to calculate prospective inundation limits, (3) use of statistically calibrated empirical equations derived from analysis of inundation data, and (4) use of statistically calibrated inundation equations that are motivated by physical-scaling arguments. Method 4 is employed in this report, as described below. The context for use of this method, however, is clarified by providing a brief synopsis of the first three methods.

\section{Historic and Geologic Evidence}

Traditionally, mass-flow hazard maps have been derived from inspection of historic and geologic evidence and use of this evidence to posit future inundation patterns (for example, Scott and others, 1998). Although this method is well established, it has two inherent limitations. First, documented past events do not necessarily provide an adequate sample of the population of all events (both past and future) that might occur in a particular area. Therefore, the extent of inundation during future events can exceed limits forecast on the basis of past events. This problem is most serious where a dearth of documentation of past events results from limited historical records and geological fieldwork. A second problem with this forecasting method is reliance on geological inference and consequent lack of reproducibility. Different geologists may examine the same historical records and field evidence, but draw different conclusions regarding the potential for future inundation. Lack of reproducibility is best overcome by formalizing predictions through use of mathematical models, which may have a physical basis, a statistical basis, or both. 


\section{Physically Based Models}

Physically based mathematical models for predicting inundation by mass flows have varying degrees of sophistication, but all such models are built on a foundation of physicalconservation laws. The most elementary models invoke only one-dimensional momentum conservation for a translating point mass (that is, Newton's second law of motion). The first model of this type was presented by Heim (1932), and it led to the famous equation $H / L=\tan \phi$, where $H$ is the vertical distance descended by the mass, $L$ is the predicted horizontal distance traversed by the mass, and $\phi$ is the Coulomb angle of sliding friction, which typically ranges from about 30 to 40 degrees in experimental tests. This model famously underpredicts the extent of runout $(L)$, particularly if mass flows are saturated with water (for example, debris flows, Iverson, 1997), or if their volumes exceed about $10^{6} \mathrm{~m}^{3}$ (Heim, 1932; Hsu, 1975; Scheidegger, 1973).

One approach to remedying the failing of the Heim (1932) model involves use of resistance formulae other than that for Coulomb friction. For example, viscosity coefficients or fixed yield-strength coefficients have been suggested as alternatives to tan $\phi$ (for example, Voight and others, 1983; Johnson, 1984; Dade and Huppert, 1998). A significant problem with this approach is that the relevance of such resistance coefficients is not supported by experimental data (Iverson, 2003).

Basal fluid pressure can be invoked as a means of modifying Coulomb friction (for example, Shreve, 1968; Sassa, 1988). Pore-fluid pressure effects are clearly evident in experimental data, but it is difficult to estimate the degree to which high basal fluid pressures will develop and persist in any particular mass flow. Some authors have assigned a basal pore-pressure distribution that fits experimental observations (for example, Iverson, 1997), whereas others have calculated pore-pressure distributions based on the porous-media consolidation theory (for example, Savage and Iverson, 2003), but good constraints for applying these approaches to field phenomena are still lacking.

The most elaborate physically based models take into account multidimensional mass and momentum conservation, as well as pore-pressure evolution, and they thereby reduce the need for calibration of flow resistance (for example, Iverson and Denlinger, 2001; Denlinger and Iverson, 2001). However, such physically-based models demand considerable input data, as well as computationally intensive solution techniques, and they remain an active area of research (Denlinger and Iverson, 2004; Iverson and others, 2004; Iverson, 2005). Application of such models to practical hazard assessment is in its earliest stages.

\section{Empirical Models}

Empirical equations, that are statistically calibrated, provide an alternative to physically based mathematical models. For example, analysis of data on the distal limits of inundation by rock avalanches has led several authors to propose that $H / L$, as used in the Heim (1932) equation, depends systematically on avalanche mass or volume (for example, Heim, 1932; Scheidegger, 1973; Hsu, 1975). Calibration of the relationship between $H / L$ and $V$ then provides a basis for prediction. However, this method takes no account of the effect of runout-path topography on the distal or lateral limits of inundation, an effect that can be apparent to casual observers.

Some authors used empirically calibrated limits for debris-flow stoppage to predict debris-flow progress through successive channel cross-sections. Benda and Cundy (1990) used an empirical model based on channel-junction angles $\left(\geq 70^{\circ}\right)$ and channel gradients $\left(<20^{\circ}\right)$ to predict runout termination for small debris flows in finely dissected, forested landscapes. Fannin and Rollerson (1993) used channel confinement (width to depth ratios) to track debris-flow progress down valley through analysis of the channel at successive sections. Fannin and Wise (2001) used slope geometry and net changes in volume for successive sections of a channel to infer whether or not a debris flow was likely to entrain or deposit sediment. Changes in flow volume were then assessed for each section until the cumulative volume was zero.

Other authors have focused on debris-flow flow volume as a basis for predicting runout. Adopting the methodology developed by Iverson and others for lahars (1998), Crosta and others (2003) found that planimetric areas inundated by diverse debris flows were nearly proportional to flow volume raised to the $2 / 3$ power. Rickenmann (1999) used the product of debris-flow volume and height of source area to predict runout distance. Cannon (1989) reported that the lengths of debris-flow runout paths are proportional to the rate at which flow volume is lost due to progressive deposition.

For rock avalanches, Li Tianchi (1983) related volume to inundated planimetric area, $(\log ($ Area $)=1.8807+0.5667$ $\log V$ ), and with statistical methods, produced a pair of prediction curves for runout-path length and width for a given vertical relief and flow volume. Kilburn and Sorenson (1998) concluded that the runout distance $L$ is described by $L=\alpha V^{1 / 2}$ where $\alpha=3-40$ is a calibrated coefficient. For both volcanic rock avalanches and lahars, Vallance and Scott (1997) observed a dimensionally homogenous power-law relationship between flow volume and planimetric area of inundation, analogous to the result reported by Crosta and others (2003) for debris flows.

\section{Statistical Models Motivated by Physical Scaling}

Several authors have used scaling arguments to bolster the proposition that planimetric areas inundated by rock avalanches should be proportional to $V^{2 / 3}$ (for example, Davies, 1982; Hungr, 1990; Dade and Huppert, 1998; Kilburn and Sorensen, 1998; Legros, 2002). All of these authors presented data that broadly supported this contention, resulting in a compelling body of evidence. 
Iverson and others (1998) extended these ideas by postulating that both the total, planimetric area $(B)$ and the maximum valley cross-sectional area $(A)$ inundated by a passing lahar should be proportional to flow volume raised to the $2 / 3$ power. Statistical analysis of a dataset for 36 lahars at 9 volcanoes was used to test and confirm the validity of these $2 / 3$ power laws. Optimal values of the proportionality coefficients were determined by using regressions of log-transformed data, yielding the following predictive equations:

$$
\begin{aligned}
& A=0.05 V^{2 / 3} \text { for cross-sectional area, and } \\
& B=200 V^{2 / 3} \text { for planimetric area. }
\end{aligned}
$$

These equations have quantitative confidence limits, which were determined by statistics associated with the regression analysis. The coefficients 0.05 and 200 in equations 1 and 2 were specified by using only one significant digit, as the confidence limits imply that greater precision is inappropriate. Another important aspect of equations 1 and 2 is that they describe the maximum extent of inundation by an average flow. Such inundation limits do not necessarily correspond with the limits of deposits left by the flow because some reaches of the flow path may not be subject to deposition.

Together, equations 1 and 2 suffice for delineating inundation limits on maps, provided that $V$ is known, and the

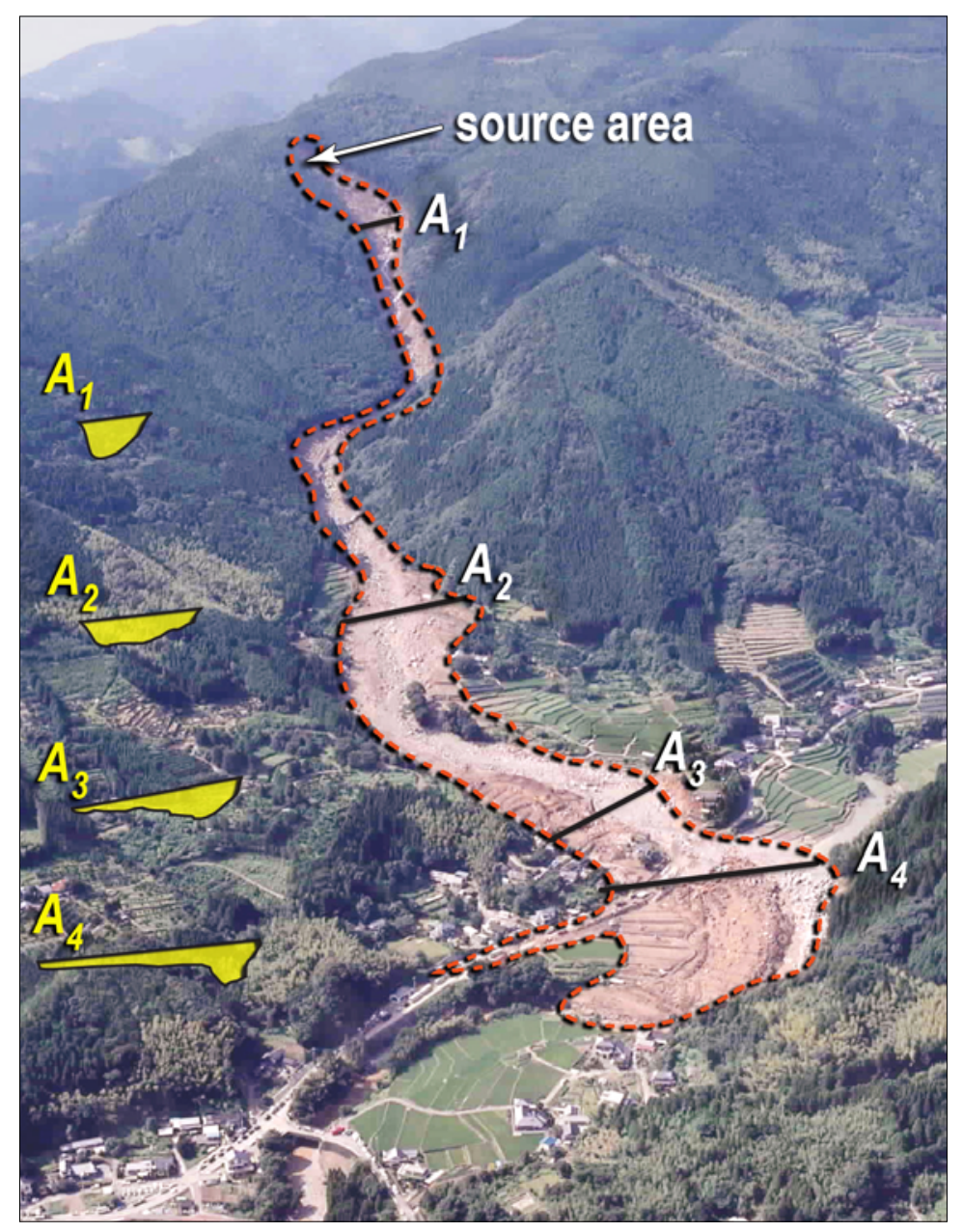

Figure 1. Schematic inundation limits of a debris flow moving downvalley from a source area. The maximum inundated valley crosssectional area, $A$, is shown for four transects (yellow). These highlighted cross sections represent inundation limits during peak flow passage, not necessarily the limits of post-flow deposition. The total inundated planimetric area, $B$, is shown by the dashed red line. Photograph is from the July 20, 2003, debris flow at Minamata in Kyushu, Japan, (Sidle and Chigira, 2004). 
topography downslope or downstream from the lahar source area is known (fig. 1). Relative to other empirical methods, an advantage of the Iverson and others (1998) method is that it makes full use of three-dimensional topographic constraints for forecasting inundation.

Because flow-volume $V$ is the independent variable in the method of Iverson and others (1998) and because the volumes of future lahars are indeterminate, forecasts of inundation limits generally postulate a range of prospective $V$-values. Inundation limits $A$ and $B$ are then calculated for the range of postulated $V$ 's. This procedure results in a nested set of inundation hazard zones, which depict the combined effect of uncertainties about the volumes and behaviors of future flows. Selection of appropriate $V$-values depends on geological knowledge, and ideally, on recurrence probabilities determined for flows with various $V$ 's (Iverson and others, 1998). However, data suitable for calculating such probabilities commonly are unavailable, and geological inferences about hydrologic contributing areas, thicknesses of soil mantles, and the magnitudes of events in similar settings provide the main basis for selecting prospective flow volumes.

\section{Objectives}

The overall objective of this study is to extend the hazard-zone delineation methodology of Iverson and others (1998) to nonvolcanic debris flows and rock avalanches. To attain this objective, several steps are taken and are enumerated here.

(1) Assemble a database consisting of flow volumes $(V)$ paired with maximum inundated valley cross-sectional areas $(A)$ and (or) total inundated planimetric areas $(B)$ for a large number of nonvolcanic debris flows and rock avalanches (fig. 2). This database parallels that assembled for lahars by Iverson and others (1998) and partly reproduces the rockavalanche databases assembled by Li Tianchi (1983), Legros (2002), and others.

(2) Use the database to test whether power-law equations with specified 2/3-exponents satisfactorily predict inundatedplanimetric and cross-sectional areas as functions of flow volume for nonvolcanic debris flows and rock avalanches. This test involves determining the goodness of fit of the $2 / 3$ power-law equations, as well as statistical comparison of these

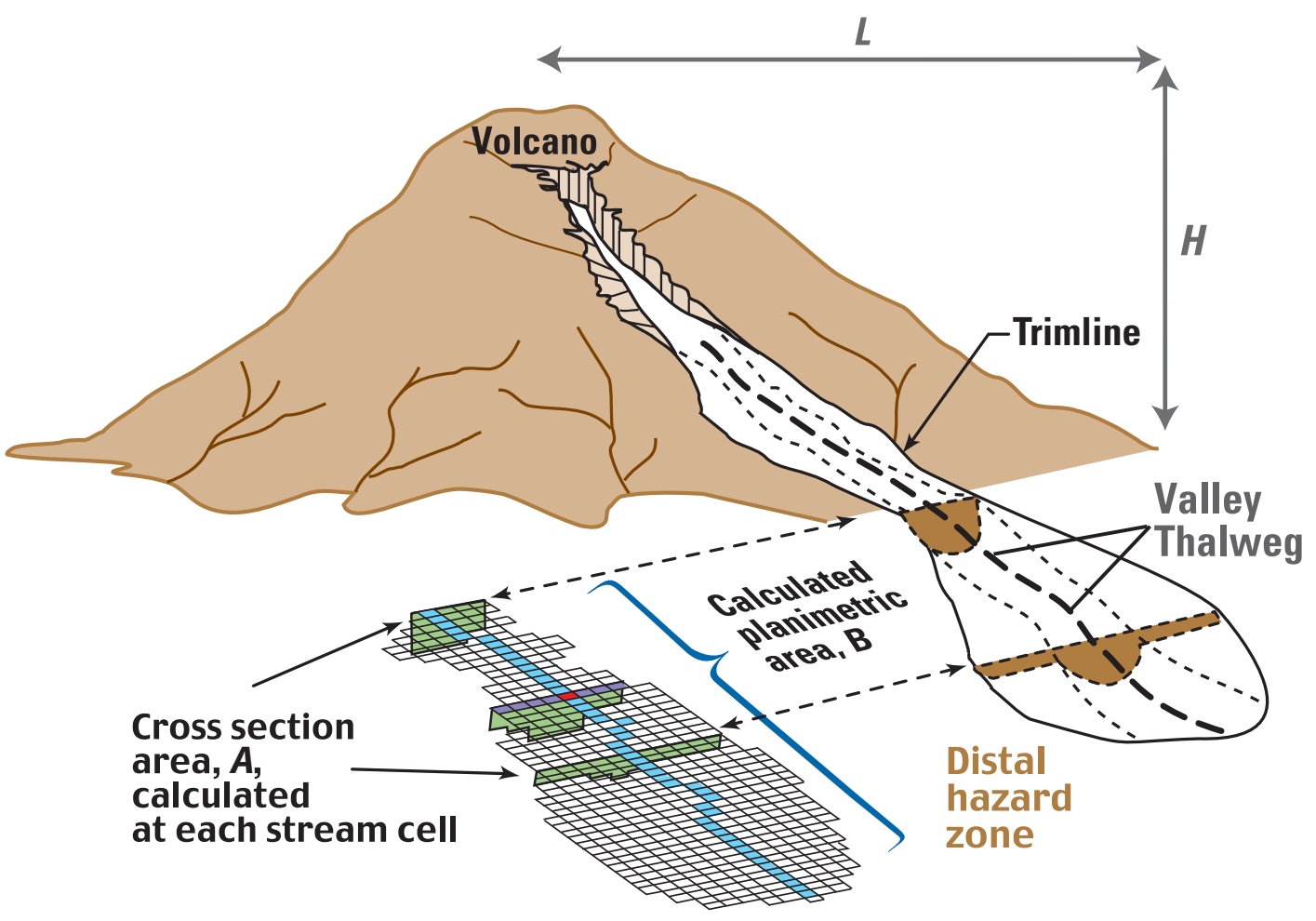

Figure 2. Diagram showing the maximum inundated cross-sectional area, $A$, and total inundated planimetric area, $B$, of a lahar runout path downstream from a source area on a volcano. The downstream edge of the source area is delineated by using an $\mathrm{H} / \mathrm{L}$ cone in this instance. Figure modified from Iverson and others (1998). 
equations to alternative statistical models. If the $2 / 3$ power-law relationships are satisfactory, then for each type of flow it is appropriate to pursue a subsequent step - testing the hypothesis that the inundation-area equations,

$$
\begin{aligned}
& A=\alpha_{1} \mathrm{~V}^{2 / 3} \text {, and } \\
& B=\alpha_{2} \mathrm{~V}^{2 / 3},
\end{aligned}
$$

with calibrated $\alpha$-coefficients, provide distinguishable models for different types of flows. In this context, differing values of the calibrated $\alpha$-coefficients imply differing degrees of flow mobility.

(3) Implement the calibrated predictive equations by embedding them in the LAHARZ computer program and modifying the criteria for identification of source areas to extend the use of the software to nonvolcanic flows. Iverson and others (1998) identified prospective lahar source areas within any valley that drains the upper slopes of a volcano. Upper slopes were defined by using an " $H / L$ cone" in which $L$ is the horizontal distance from the volcano summit to any point downslope, and $H$ is the elevation difference between those two points (fig. 2). Generally, $H / L$-values between 0.2 and 0.3 are well suited for identifying lahar source areas on large composite volcanoes (for example, Mount Rainier in the Cascade Range of the United States), and values up to 0.7 are used for smaller or multipeaked volcanoes (for example, Santa Ana volcano in El Salvador). However, it is more difficult to identify prospective source areas in dissected terrain that is not characterized by a dominant topographic feature, such as a volcano. Therefore, a new method for identification of source areas of nonvolcanic debris flows is described in the LAHARZ Application section.

(4) Use GIS and a modified version of LAHARZ to create a debris-flow hazard map for a range of hypothetical flow volumes in a drainage basin in a geographic area where precise digital-topographic data are available.

\section{The Database}

Diverse data sources and events in diverse geographic locations (with diverse climate, bedrock, topography, and vegetation) were used to assemble a dataset suitable for extending the methodology of Iverson and others (1998) to nonvolcanic debris flows and rock avalanches. All data and data sources are tabulated in appendixes A and B.

In assembling the dataset, descriptions of documented runout paths of debris flows and rock avalanches of prehistoric and historic events were found in scientific literature, unpublished reports and maps, and personal communications or field notes. As described in the original sources, evidence used to infer maximum inundated cross-sectional area, $A$, includes high-flow marks indicated by strandlines, levees, embedded gravels, or the height of stripped bark on the trunks of adjacent trees, and the height of $\log$ jams. Therefore, area $A$ depends on the maximum stage (for example, elevation) of inundation during passage of flow through a cross section-and not on the area blanketed by deposits. Evidence used to infer total, inundated planimetric area, $B$, includes the extent of coarse deposits that form the levees and snout of a granular flow, or the lateral limits of any evidence of high-flow lines. This total, planimetric area includes all parts of the flow path, whether or not they are blanketed by deposits, but does not include areas affected by subsequent flooding or hyperconcentrated stream flow. Pairing of data on inundated cross-sectional area $A$ and (or) planimetric area $B$ with flow-volume data is necessary because, from a statistical standpoint, flow volume, $V$, is the independent variable, and $A$ and $B$ are the dependent variables. Ideally, values of all three variables are known for any particular event.

Determination of the inundation variables $A, B$, and $V$ commonly is complicated by lack of accurate knowledge of topography before and immediately after an event. The most useful data come from surveys made shortly after an event that record high-flow marks and from surveys that include detailed topographic maps of the land surface before and after an event. However, because the motivations behind the various papers and reports on debris flows and avalanches differ, the type and quality of data vary significantly. In many cases areas $A$ and $B$ implicitly include the effects of any channel scour that occurred during or following flow events because areas $A$ and $B$ are based entirely on post-event evidence.

Many reports did not document the values of $A, B$, and $V$ explicitly, thus the quality and quantity of diverse information dictated whether or not the report could be used to reconstruct the values of $A, B$, and $V$. Reports fell into three categories. Reports that included detailed maps of deposit extent and channel cross-section surveys that identified the pre-flow surface were most useful. The second type of report offered sketches with descriptive details on total runout distance; maximum- and average- deposit dimensions at road, railway, or trail crossings; and maximum and average flow widths in well-constrained channels. These dimensions were used to calculate one or more of the inundation variables in a piece-wise fashion. In these cases, calculations made by using average, maximum, or minimum dimensions were used to estimate the difference in calculated outcomes. As long as the results agreed to one significant digit, calculations from these descriptive reports were included in the database. The third report category either provided data that could not be used to reconstruct the inundation variables objectively and reproducibly, or it provided data suitable for reconstructing only one of the three inundation variables $(V, A, B)$. Reports from this third category were excluded from the database.

If reports included maps of the deposit without a quantitative assessment of inundation variables, a simple method for determining area $B$ was used, which entailed overlaying a fine grid on the map, counting the boxes within the mapped extent, 
and using the map scale to calculate the total area. The same procedure was used to determine cross-sectional area, $A$, for any surveyed channel profiles that included topography from before and after an event.

Despite the availability of some high-precision field measurements obtained through detailed surveying or calculations done in GIS, the database in appendix A lists only one significant digit for each volume and area entry. Values of volume and area generally are accurate to only one or two significant digits due to the following factors (1) the small scale at which surveys were done and the maps were produced, (2) the degree of erosion of deposits and loss of reconstructable evidence between the time of the event and the time of the study; and (3) the uncertainty of inferences from descriptive reports used to reconstruct the inundation variables where they were not specifically reported. It is important to point out that precision greater than one significant digit would have little effect on results reported in this study as the data are analyzed in the context logarithmic plots and power-law equations. Therefore, the order of magnitude of the data is paramount.

Some atypical and ambiguous events were intentionally excluded from the dataset. For example, events in which multiple debris flows coalesced, such that inundation variables for a single event were obscured, were excluded. Also excluded were events that followed in rapid succession such that flowpath features were overprinted or undifferentiable, or where pre- and post- event topography was not discernible. Cases in which the flow would be characterized as a hyperconcentrated water flood during a portion of the runout also were excluded from the dataset.

Data for 64 debris flows (44 $V-B$ pairs and $50 V-A$ area pairs) and 143 rock avalanches (142 $V$ - $B$ pairs and $12 V-A$ pairs) are included in the database (appendix A). Rock-avalanche volumes range between $10^{5}$ and $10^{11} \mathrm{~m}^{3}$ and correspond respectively to the Felsberg event (Heim, 1921) and the Flims event (Jackli, 1957), both in The Alps. Debris-flow volumes range between $10^{1}$ and $10^{7} \mathrm{~m}^{3}$, which correspond to USGS debris-flow flume experiments (Iverson and others, 1992) and the 900 years B.P. (before present) Upper Lillooet River debris flow in British Columbia (Jordan, 1994). For lahars, we used data compiled by Iverson and others (1998), which include events ranging from about $10^{5}$ to $10^{10} \mathrm{~m}^{3}$ in volume.

All data assembled for lahars, debris flows, and rock avalanches are plotted in figure 3. A log-log graph is used to depict the data because on such a graph, power laws of the form $A=\alpha V^{2 / 3}$ plot as straight lines with slopes of $2 / 3$. Although considerable data scatter is evident in figure 3 , the linear-data trends evident in the figure help motivate investigation of such 2/3-power laws as suitable models.

\section{Statistical Analysis of the Data}

The second objective of this report is to use the assembled datasets to develop and test predictive inundation equa- tions. We focused on power-law equations because preliminary analyses by Griswold (2004) showed that power laws fit the data better than did alternative simple regression models (that is, linear, exponential, or quadratic).

First, we used results from an analysis of variance (ANOVA) to determine whether equations 3 and 4 , with specified $2 / 3$ exponents and statistically calibrated $\alpha$-coefficients, provide appropriate models for both debris flows and rock avalanches; and we compared these models to best-fit powerlaw regression models with adjustable exponents. Second, we examined the statistical difference between the calibrated $\alpha$-coefficients by using a technique involving a dummy variable and multiple linear-regression analysis to determine whether one set of predictive equations would be adequate for multiple types of flows. Third, we described the statistical uncertainty inherent in the predictive equations. Finally, we considered geological interpretation and physical implications of the calibrated inundation equations for the various types of flows.

Prior to statistical testing, the data and power-law equations are transformed logarithmically. Use of log-transformed data acknowledges that data scatter increases roughly in proportion to the data magnitude, as shown in figure 3. Log transformation also enables use of standard least-squares regression methods when fitting power-law equations to the data. Following log-transformation, the power-law equations to be tested and calibrated become

$$
\begin{gathered}
\log A=\log \alpha_{1}+\beta_{1} \log V, \text { and } \\
\log B=\log \alpha_{2}+\beta_{2} \log V,
\end{gathered}
$$

where the $\log \alpha$ terms represent $y$-intercepts, and the $\beta$-coefficients (slopes) are hypothesized to be $2 / 3$.

\section{Test for Differences in Slope}

In this section we examine whether the proposed equations with a specified slopes $(\beta=2 / 3)$ and calibrated intercepts $(\log (\alpha))$ provide viable alternatives to linear regression equations with best-fit slopes and intercepts. A preliminary question is whether or not there is a significant relationship between the dependent and independent variables, and answers to both questions rely on the outcome of an analysis of variance (ANOVA) and the associated F-statistic.

For each paired data set $(V, A$ or $V, B$ for each type of flow) the best-fit linear regression models (referred to hereafter as "Model 1") have two adjustable parameters (slope and $y$-intercept) to be calibrated by using a standard procedure of minimizing the residual sum of squares. The specified 2/3-slope models ("Model 2"), as well as specified zero-slope models ("Model 3"), each have one adjustable parameter (the $y$-intercept) to be calibrated by minimizing the sum of squares. The two questions to be addressed are (1) "Do the models with 


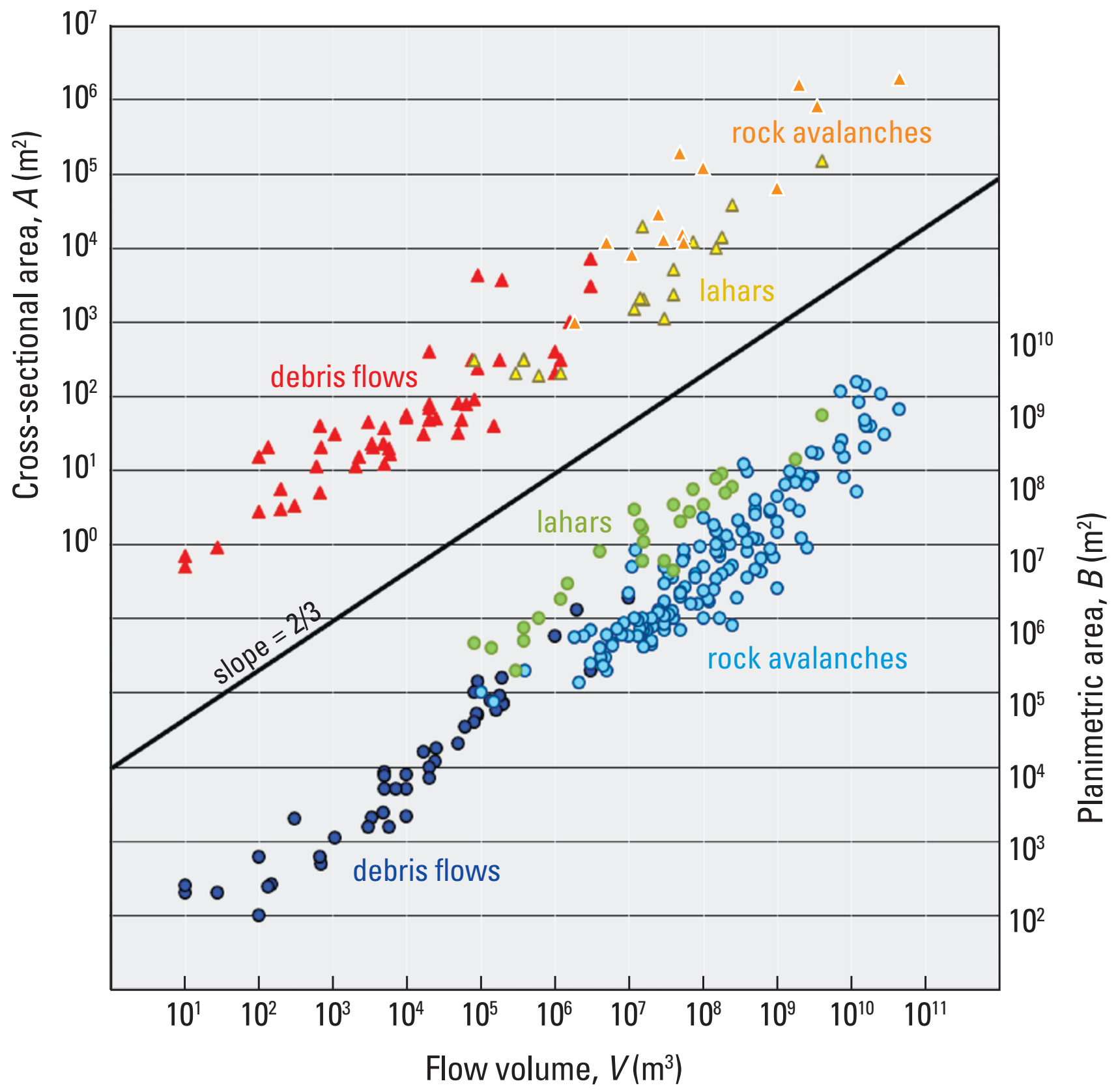

Figure 3. Scatter plot of all data compiled for debris flows, rock avalanches, and lahars. Flow volume, $V$, is the independent variable and maximum inundated cross-sectional area, $A$, and total, planimetric area, $B$, are the dependent variables. All data and data sources are tabulated in appendixes $A$ and $B$. 
nonzero slopes fit the data significantly better than a specified zero-slope model (a horizontal line expressing no linear relationship between the variables)?" and (2)" If the models with nonzero slopes fit the data best, is there a significant difference between the fit attained by using the best-fit linear regression model and the specified 2/3-slope model?" If there is no statistically significant difference, then the $2 / 3$-slope model provides a suitable representation of the data.

The datasets and regression lines representing the three alternative models for each dataset are plotted in figures 4-7. The corresponding ANOVA results are listed in tables 1-4 under column headings DF-A1 for debris flow $V, A$ dataset Model 1; DF-B2 for debris flow $V, B$ dataset Model 2; and so forth. For debris flows and rock avalanches with 2 datasets each ( $V, A$ pairs and $V, B$ pairs) and 3 statistical models of each dataset, there are 12 models to consider. Tables 5 and 6 summarize the candidate predictive equations for Models 1 and 2 (the best-fit regression and specified 2/3 slope models) for rock avalanches and debris flows and also list the analogous predictive equations for lahars (reproduced from Iverson and others, 1998).

Values of the coefficient of determination $\left(r^{2}\right)$ listed in tables 1-4 indicate how well the sloped models surpass the zero-slope model in describing the data. Following Weisberg (1985), the coefficient of determination, $r^{2}$, is computed as

$$
r^{2}=1-\left(\frac{S S_{\text {sloped_models }}}{S S_{\text {Zero_slope_model }}}\right)
$$

where SS is the residual sum of squares that summarizes deviations of data values from a model trend line. The residual sum of squares for the sloped models is necessarily smaller than those of the zero-slope models, provided that some linear relationship exists between $V$ and $A$ and between $V$ and $B$. Our datasets, all have $r^{2}$-values greater than 0.77 (tables 1-4), and we infered that sloped models are better than the zero-slope models that use only the mean value to represent the data.

The F-test is used to compare the specified-slope models (Models 2 and 3 in tables 1-4) against the best-fit regression model (Model 1) for each dataset. More specifically, the F-test evaluates the credibility of a null hypothesis $\left(\mathrm{H}_{0}\right)$ and alternate hypothesis $\left(\mathrm{H}_{1}\right)$ that state

$\mathrm{H}_{0}$, The specified-slope model (Model 2, with $\beta_{1}=2 / 3$; or Model 3, with $\beta_{1}=0$ ) fits the data as well as the best-fit regression model (Model 1, with $\beta_{1}$ adjustable);

$\mathrm{H}_{1}$, The specified-slope model (Model 2 or Model 3) does not fit the data as well as the best-fit regression model (Model 1).

The $F$ statistic is computed as (Weisberg, 1985)

$$
F=\frac{\left(S S_{\text {null }}-S S_{\text {best-fit_regression }}\right) /\left(D F_{\text {null }}-D F_{\text {best-fit_regression }}\right)}{\left(S S_{\text {best-fit_regression }} / D F_{\text {best-fit_regression }}\right)}
$$

where $S S$ is the residual sum of squares and $D F$ is the residual degrees of freedom. For each model, $D F=n-N$, where $n$ is the number of data pairs and $N$ is the number of calibrated parameters in the model. ( $N=2$ for the best-fit regression models and $N=1$ for the specified-slope models.) The computed $F$ statistic-value is compared against tabulated values of the F-distribution (for example, Haan, 1977), and a probability of the F-statistic falling within a specified range of the F-distribution is determined. For example, a probability (p-value) of 0.01 indicates that, if the null hypothesis were true, there would be at least a 1 percent chance of obtaining a calculated F-value smaller than the tabulated F-value. Our key questions are whether or not calculated F-statistics support rejection of Model 3 (specified zero slope), but do not support rejection of Model 2 (specified 2/3 slope).

For both debris flows and rock avalanches, the calculated F-statistics for the specified 2/3-slope models (Model 2) are smaller than tabulated F-values for $\mathrm{p}=0.01$, and confidence that the associated null hypothesis can be rejected consequently is small (table 5). The computed F-statistics for the specified zero-slope models (Model 3) are much greater than tabulated F-values for $\mathrm{p}=0.01$, and therefore, the confidence with which this null hypothesis can be rejected is great (table 7). Thus, there is little statistical evidence that the bestfit regression models fit the data significantly better than the specified 2/3-slope models, but there is strong evidence that the best-fit regressions provide a better fit to the data than does a horizontal line. Therefore, for purposes of forecasting hazard zones, we adopted the 2/3-slope models (table 6 ) as acceptable fits to the data.

\section{Test for Difference in Intercepts}

Having shown that power-law equations with specified 2/3 slopes and calibrated intercepts provide suitable models of the data, we examined the assumption that the inundation areas for the three types of landslides (debris flows, rock avalanches, and lahars) yield power-law equations that are statistically distinct. This can be done by showing that the $y$-intercepts of the log-transformed power-law equations are statistically different.

Testing the intercepts for significant differences can be accomplished by combining any two datasets (for example, rock avalanche and debris flow $V, A$ data), calibrating a regression equation for the combined group, and testing whether the resulting regression equation fits the data as well as either of the two regression equations for the individual datasets. If the individual and combined regressions are shown to have statistically similar intercepts, then one equation adequately represents the data for both flow types. Alternatively, the intercept for the single dataset may be significantly different from that for the combined datasets, in which case separate equations for each flow type are warranted. Comparing pairs of datasets (for 


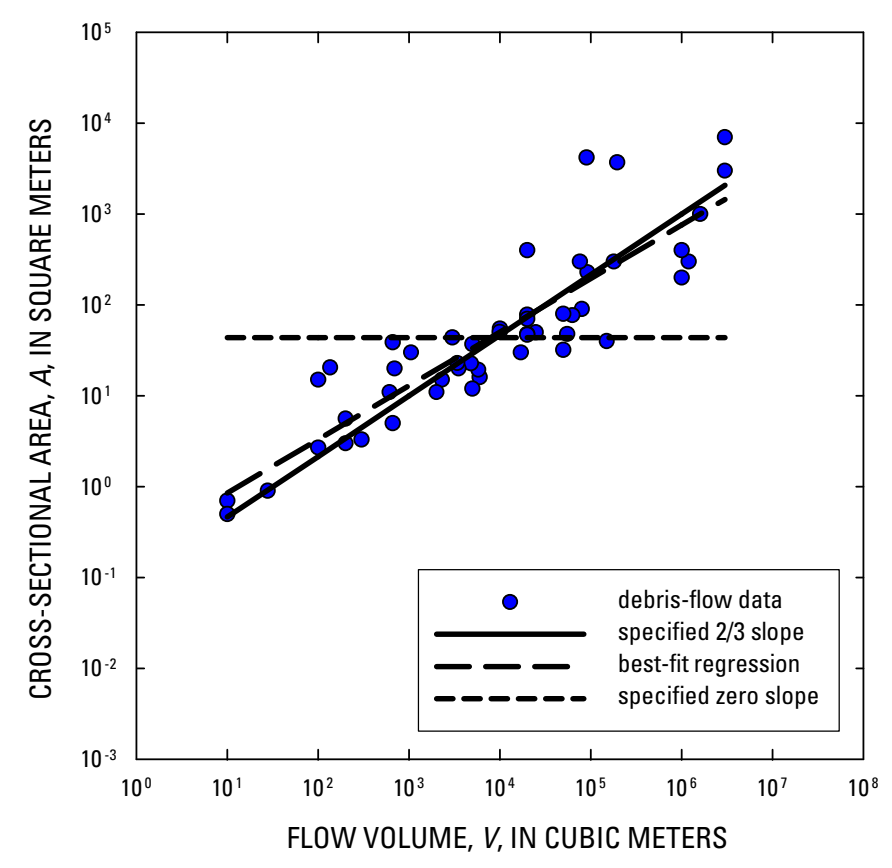

Figure 4. Debris-flow data and three regression models for cross-sectional area (denoted by DF-A1, A2, A3 in table 1). Model 1 is the best-fit regression. Model 2 is the specified 2/3-slope model. Model 3 is the specified zero-slope model expressing that cross-sectional area has no dependence on flow volume.

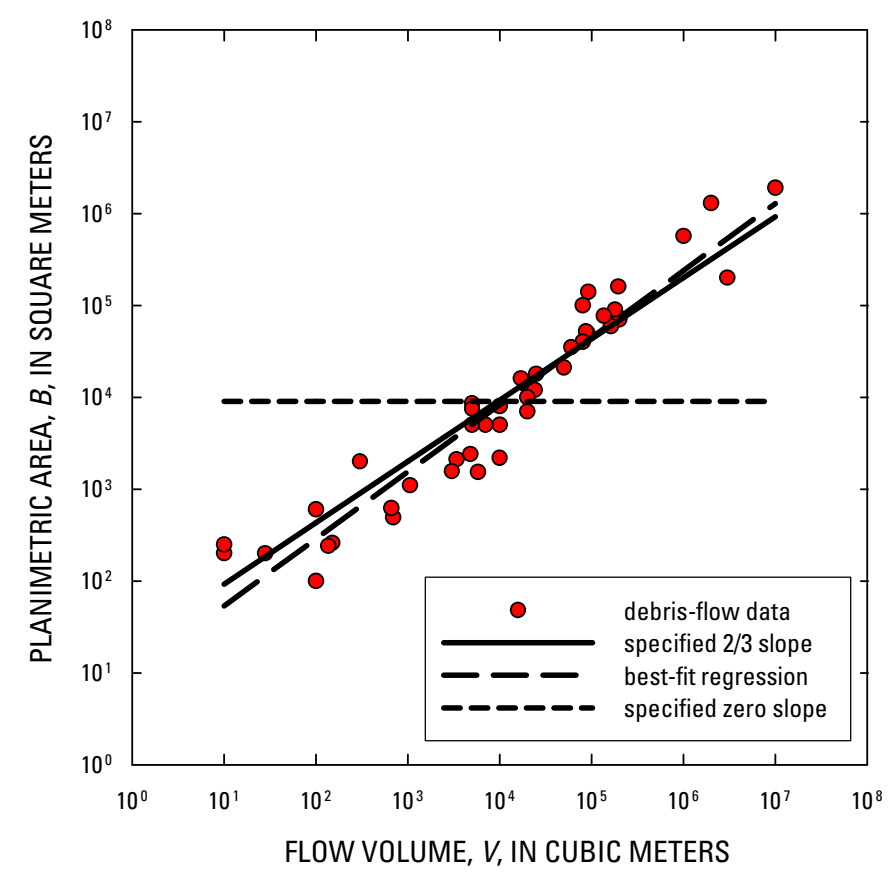

Figure 5. Debris-flow data and three regression models for planimetric area (denoted by DF-B1, B2, B3 in table 2). Model 1 is the best-fit regression. Model 2 is the specified 2/3-slope model. Model 3 is the specified zero-slope model expressing that planimetric area has no dependence on flow volume.

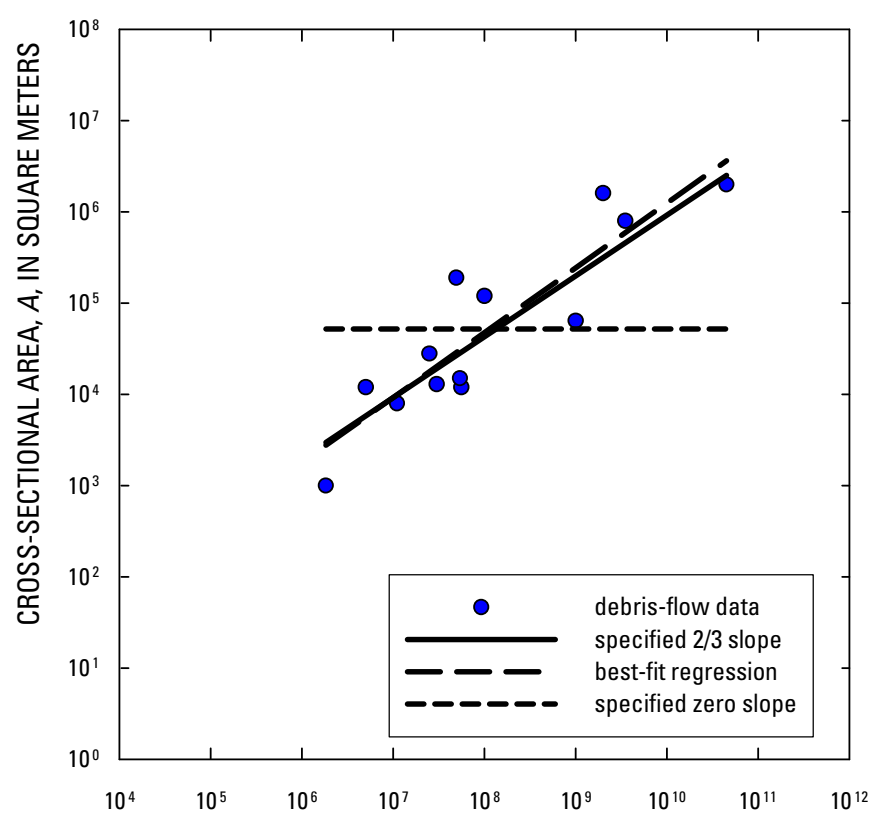

FLOW VOLUME, $V$, IN CUBIC METERS

Figure 6. Rock-avalanche data and three regression models for cross-sectional area (denoted by RA-A1, A2, A3). Model 1 is the best-fit regression. Model 2 is the specified 2/3-slope model. Model 3 is the specified zero-slope model expressing that crosssectional area has no dependence on flow volume.

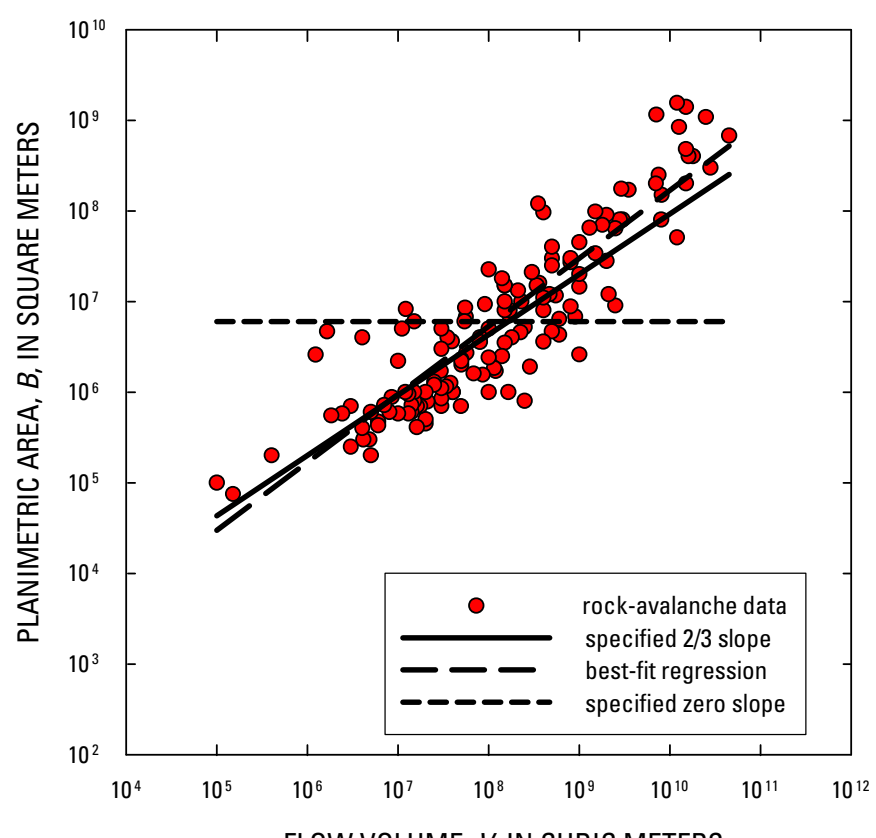

Figure 7. Rock-avalanche data and three regression models for planimetric area (denoted by RA: B1, B2, B3). Model 1 is the best-fit regression. Model 2 is the specified 2/3-slope model. Model 3 is the specified zero-slope model expressing that planimetric area has no dependence on flow volume. 
Table 1. Parameters and analysis-of-variance statistics for alternative linear models of log-transformed debris-flow data for inundated cross-sectional area, $A$, as a function of flow volume, $V$.

\begin{tabular}{|c|c|c|c|}
\hline \multirow[b]{2}{*}{ Parameter } & \multicolumn{3}{|c|}{ Models for prediction of cross-sectional area of inundation, $\boldsymbol{A}$} \\
\hline & $\begin{array}{c}\text { Best-fit regression, } \\
\text { (Model DF-A1) }\end{array}$ & $\begin{array}{c}\text { Specified 2/3 slope, } \\
\text { (Model DF-A2) }\end{array}$ & $\begin{array}{c}\text { Specified zero slope, } \\
\text { (Model DF-A3) }\end{array}$ \\
\hline Calibrated slope of the line & 0.59 & 0.67 & 0 \\
\hline $\begin{array}{l}\text { Calibrated intercept of line at } \log V=0 \\
\alpha \text {-coefficient }\end{array}$ & $\begin{array}{c}-0.66 \\
\log ^{-1}(-0.66)=0.22\end{array}$ & $\begin{array}{c}-0.97 \\
\log ^{-1}(-0.97)=0.11\end{array}$ & $\begin{array}{c}1.6 \\
\log ^{-1}(1.6)=44\end{array}$ \\
\hline Number of data pairs, $\boldsymbol{n}$ & 50 & 50 & 50 \\
\hline Residual mean square, $\boldsymbol{M S}$ & 0.19 & 0.20 & 0.84 \\
\hline Standard error of model, $\sigma$ & 0.43 & 0.44 & 0.91 \\
\hline Coefficient of determination, $r^{2}$ & 0.78 & 0.77 & 0.0 \\
\hline F-statistic, (comparison to model A1) & NA & 3.2 & 170 \\
\hline
\end{tabular}

Table 2. Parameters and analysis-of-variance statistics for alternative linear models of log-transformed debris-flow data for inundated-planimetric area, $B$, as a function of flow volume, $V$.

\begin{tabular}{|c|c|c|c|}
\hline \multirow[b]{2}{*}{ Parameter } & \multicolumn{3}{|c|}{ Models for prediction of planimetric area of inundation, $B$} \\
\hline & $\begin{array}{l}\text { Best-fit regression, } \\
\text { (Model DF-B1) }\end{array}$ & $\begin{array}{c}\text { Specified 2/3 slope, } \\
\text { (Model DF-B2) }\end{array}$ & $\begin{array}{l}\text { Specified zero slope, } \\
\text { (Model DF-B3) }\end{array}$ \\
\hline Calibrated slope of the line & 0.73 & 0.67 & 0 \\
\hline Calibrated intercept of line at $\log V=0$ & 1.0 & 1.3 & 4.0 \\
\hline$\alpha$-coefficient & $\log ^{-1}(1.0)=10$ & $\log ^{-1}(1.3)=19$ & $\log ^{-1}(4.0)=9,000$ \\
\hline Number of data pairs, $\boldsymbol{n}$ & 44 & 44 & 44 \\
\hline Residual mean square, $\boldsymbol{M S}$ & 0.099 & 0.10 & 1.2 \\
\hline Standard error of model, $\sigma$ & 0.31 & 0.32 & 1.1 \\
\hline Coefficient of determination, $\boldsymbol{r}^{2}$ & 0.92 & 0.91 & 0.0 \\
\hline F-statistic, (comparison to model B1) & NA & 3.7 & 470 \\
\hline
\end{tabular}

Table 3. Parameters and analysis-of-variance statistics for alternative linear models of log-transformed rock-avalanche data for inundated cross-sectional area, $A$, as a function of flow volume, $V$.

\begin{tabular}{lccc}
\hline \multirow{2}{*}{ Parameter } & \multicolumn{2}{c}{ Models for prediction of cross-sectional area of inundation, $\boldsymbol{A}$} \\
\cline { 2 - 4 } & $\begin{array}{c}\text { Best-fit regression, } \\
\text { (Model RA-A1) }\end{array}$ & $\begin{array}{c}\text { Specified 2/3 slope, } \\
\text { (Model RA-A2) }\end{array}$ & $\begin{array}{c}\text { Specified zero slope, } \\
\text { (Model RA-A3) }\end{array}$ \\
\hline Calibrated slope of the line & 0.71 & 0.67 & 0 \\
Calibrated intercept of line at $\log \boldsymbol{V}=0$ & -1.0 & -0.64 & 4.7 \\
$\quad \boldsymbol{\alpha}$-coefficient & $\log ^{-1}(-1.0)=0.10$ & $\log ^{-1}(-0.64)=0.23$ & 13 \\
Number of data pairs, $\boldsymbol{n}$ & 13 & 12 & 13 \\
Residual degrees of freedom, $\boldsymbol{D F}$ & 11 & 2.3 & 12 \\
Residual sum of squares, $\boldsymbol{S S}$ & 1.9 & 0.19 & 12 \\
Residual mean square, $\boldsymbol{M S}$ & 0.17 & 0.44 & 0.98 \\
Standard error of model, $\boldsymbol{\sigma}$ & 0.41 & 0.80 & 0.99 \\
Coefficient of determination, $\boldsymbol{r}^{2}$ & 0.84 & 2.7 & 0.0 \\
F-statistic, comparison to model A1) & NA & & 58 \\
\hline
\end{tabular}




\section{Mobility Statistics and Automated Hazard Mapping for Debris Flows and Rock Avalanches}

Table 4. Parameters and analysis-of-variance statistics for alternative linear models of log-transformed rock-avalanche data for inundated-planimetric area, $B$, as a function of flow volume, $V$.

\begin{tabular}{|c|c|c|c|}
\hline \multirow[b]{2}{*}{ Parameter } & \multicolumn{3}{|c|}{ Models for prediction of planimetric area of inundation, $B$} \\
\hline & $\begin{array}{l}\text { Best-fit regression, } \\
\text { (Model RA-B1) }\end{array}$ & $\begin{array}{l}\text { Specified 2/3 slope, } \\
\text { (Model RA-B2) }\end{array}$ & $\begin{array}{l}\text { Specified zero slope, } \\
\text { (Model RA-B3) }\end{array}$ \\
\hline Calibrated slope of the line & 0.75 & 0.67 & 0 \\
\hline$\alpha$-coefficient & $\log ^{-1}(0.73)=5.3$ & $\log ^{-1}(1.4)=24$ & $\log ^{-1}(6.8)=6,000,000$ \\
\hline Number of data pairs, $\boldsymbol{n}$ & 142 & 142 & 142 \\
\hline Residual mean square, $\boldsymbol{M S}$ & 0.19 & 0.20 & 0.92 \\
\hline Standard error of model, $\sigma$ & 0.44 & 0.45 & 0.96 \\
\hline Coefficient of determination, $\boldsymbol{r}^{2}$ & 0.79 & 0.79 & 0.0 \\
\hline F-statistic, (comparison to model B1) & NA & 6.2 & 540 \\
\hline
\end{tabular}

Table 5. Summary table of the best-fit regression equations with calibrated slopes and intercepts (Model 1).

\begin{tabular}{lll}
\hline Debris flows, models DF-A1 and DF-B1 & $A=0.22 V^{0.59}$ & $B=10 V^{0.73}$ \\
Rock avalanches, models RA-A1 and RA-B1 & $A=0.10 V^{0.71}$ & $B=5.3 V^{0.75}$ \\
Lahars, (Iverson and others, 1998) models LA-A1 and LA-B1 & $A=0.062 V^{0.65}$ & $B=110 . V^{0.69}$ \\
\hline
\end{tabular}

Table 6. Summary table of the best-fit regression equations with specified 2/3 slopes and calibrated intercepts (Model 2). Only one significant digit is reported for the $\alpha$-coefficients.

\begin{tabular}{lll}
\hline Debris flows, models DF-A2 and DF-B2 & $A=0.1 V^{2 / 3}$ & $B=20 V^{2 / 3}$ \\
Rock avalanches, models RA-A2 and RA-B2 & $A=0.2 V^{2 / 3}$ & $B=20 V^{2 / 3}$ \\
Lahars, (Iverson and others, 1998) models LA-A2 and LA-B2 & $A=0.05 V^{2 / 3}$ & $B=200 V^{2 / 3}$ \\
\hline
\end{tabular}


lahars, debris flows, and rock avalanches), for both $V, A$ and $V$, $B$ data, to each of the individual datasets results in 12 tests.

The test procedure is formalized by adding a term to the simple linear-regression model (equation 9) to produce a multiple-regression model (equation 10):

$$
\begin{gathered}
\log A=\log \alpha_{1}+\beta_{1} \log V, \text { and } \\
\log A=\log \alpha_{1}+\beta_{1} \log V+\beta_{Z} Z .
\end{gathered}
$$

The additional term in equation 10 includes a dummy regression variable, $Z$, commonly used with categorical dataalso referred to as an indicator variable or binary variable (for example, Wesolowsky, 1976). Following Wesolowsky (1976), values for $Z$ are assigned as 0 or 1 to differentiate between two datasets used in any test. The $Z$-value assignment is 0 for the combined datasets (for example, rock avalanches and lahars planimetric areas) and 1 for the individual datasets. The form of equations 9 and 10 then implies that the individual dataset has y-intercept, $\log \alpha_{1}+\beta_{\mathrm{z}}$; and the combined dataset has intercept $\log \alpha_{1}$. The null hypothesis states that the intercepts for both the combined and individual datasets are the same, for example, that $\beta_{z}$ is zero. Rejecting the null hypothesis means that the difference in intercepts for the combined and individual datasets is significantly different from zero.

As in the preceding section, we used the F-test to evaluate the confidence with which a null hypothesis can be accepted or rejected. In this case, however, we considered whether or not null models (in which $Z=0$ in equation 10) for combined datasets are statistically distinct from models for individual data sets (denoted by $Z=1$ in equation 10). For the models summarized by equations 9 and 10 , the model equations and residual degrees of freedom for this series of F-tests are summarized in table 8 . For the case in which $\beta_{1}=2 / 3$, the residual degrees of freedom for the null models (combined dataset) are $\mathrm{n}-1$, whereas the residual degrees of freedom for the alternate models (individual datasets) are $n-2$. (The null model with $2 / 3$ slope has one free coefficient to calibrate, $\log \alpha_{1}$, whereas the alternate model representing an individual dataset with $2 / 3$ slope has two coefficients to calibrate, $\beta_{0}$ and $\beta_{Z}$ ). If the slope $\beta_{1}$ is treated as a free parameter (calibrated by regression) in each case, then the residual degrees of freedom are reduced by 1. Thus, the best-fit regression model for an individual dataset has $n-3$ residual degrees of freedom in this test. Tables 9 and 10 list the parameters used to compute the F statistics.

The results of the F-test comparing combined and individual models for cases with a specified slope of $2 / 3$ are summarized in tables 11-13, and results for equivalent tests for cases with best-fit slopes calibrated by regression are summarized in tables $14-16$. The tabulated values show that at the $p=0.01$ level, the implications of the F-test results are the same, regardless of whether or not the models with specified $2 / 3$ slopes or freely calibrated slopes are considered. Therefore, because we are interested primarily in the 2/3-slope models, our discussion below focuses exclusively on the F-test results for those models.

The F-tests comparing the intercepts for the combined datasets (for example, rock avalanches and lahars) to those for the individual datasets (either rock avalanches or lahars) yield mixed results (fig. 8-10 and tables 11-13). In half of the cases, the null hypothesis can be rejected at the $\mathrm{p}=0.01$ level, and thus, separate $y$-intercepts are warranted for individual datasets. In the other cases, the F-test results imply that little statistical difference exists between dataset y-intercepts. Detailed examination of the statistical results for specific F-tests, however, reveals some subtleties that complicate this inference.

The F-tests of greatest interest compare inundation equations for lahars and rock avalanches, which have flow-volume magnitudes that largely overlap (fig. 8, table 11). The F-tests generally confirm the visual impression that the data sets are distinct, and there is little doubt that planimetric-area inundation equations for lahars and rock avalanches have distinct $\mathrm{y}$-intercepts and warrant different inundation equations. On the other hand, there is some ambiguity in the F-test results for cross-sectional area inundation. The tests show that the lahar data are distinguishable from the combined data, but the rock avalanche data are not. The paucity of cross-section inundation data for rock avalanches is at least partly responsible for this outcome, as it results in a small value for the residual degrees of freedom, which weakens the statistical test. The second comparison is for lahars and debris flows, which have flowvolume magnitudes that overlap between $10^{5}$ and $10^{7} \mathrm{~m}^{3}$ (fig. 9, table 12). On this basis alone, the datasets might be

\begin{tabular}{|c|c|c|c|c|c|c|}
\hline & \multirow{2}{*}{$\begin{array}{c}\text { Degrees of freedom } \\
\text { (numerator, denominator) }\end{array}$} & \multirow{2}{*}{$\begin{array}{l}\text { F-value, } \\
p=0.01\end{array}$} & \multicolumn{2}{|c|}{$\begin{array}{l}\text { Specified 2/3-slope regression model } \\
\text { compared to null model }\end{array}$} & \multicolumn{2}{|c|}{$\begin{array}{l}\text { Specified zero-slope regression mode } \\
\text { compared to null model }\end{array}$} \\
\hline & & & F-statistic & p-value & F-statistic & p-value \\
\hline \multicolumn{7}{|c|}{ Debris flows } \\
\hline$V, B$ & 1,42 & 7.3 & 3.7 & 0.061 & 470 & $2.0 \times 10^{-24}$ \\
\hline \multicolumn{7}{|c|}{ Rock avalanches } \\
\hline
\end{tabular}

Table 7. Summary of results of F-tests comparing the specified-slope models to the best-fit regression model with adjustable slope. 
Table 8. Dummy variable terms and equations for null model (combined datasets) and alternate models (individual datasets).

\begin{tabular}{lcc}
\hline Model & Equation & Residual Degrees of Freedom \\
\hline Null with 2/3 slope & $\log A=\log \alpha_{1}+2 / 3 \log V$ & $\mathrm{n}-1$ \\
Alternate with 2/3 slope & $\log A=\log \alpha_{1}+2 / 3 \log V+\beta_{Z} Z$ & $\mathrm{n}-2$ \\
Null with best-fit slope & $\log A=\log \alpha_{1}+\beta_{1} \log V$ & $\mathrm{n}-2$ \\
Alternate with best-fit slope & $\log A=\log \alpha_{1}+\beta_{1} \log V+\beta_{Z} Z$ & $\mathrm{n}-3$ \\
\hline
\end{tabular}

Table 9. Parameters for computing the F-statistic to compare the specified 2/3-slope models with combined and individual datasets.

\begin{tabular}{|c|c|c|c|c|}
\hline \multicolumn{5}{|c|}{ Combined datasets (null model) } \\
\hline Rock avalanche & Lahar & Debris flow & Residual sum of squares, $S S_{\text {null }}$ & Number of samples, $n_{1}+n_{2}$ \\
\hline \multirow{2}{*}{$\mathrm{X}$} & & \multirow{2}{*}{$\mathrm{X}$} & 13.01 & 63 \\
\hline & & & $V, B \quad 32.83$ & 186 \\
\hline \multirow{3}{*}{$\mathrm{X}$} & \multirow{2}{*}{$X$} & \multirow{3}{*}{ X } & 8.008 & 31 \\
\hline & & & 46.13 & 169 \\
\hline & X & & $V, A \quad 13.34$ & 68 \\
\hline Rock avalanche & Lahar & Debris flow & Residual sum of squares, $S_{\text {regr }}$ & Number of samples, $n$ \\
\hline \multirow{4}{*}{$\mathrm{X}$} & \multirow{4}{*}{ X } & & 2.314 & 13 \\
\hline & & & 27.95 & 142 \\
\hline & & & 2.008 & 18 \\
\hline & & & 2.064 & 27 \\
\hline
\end{tabular}

$\mathrm{V}$, A denotes the paired dataset for volume-cross sectional area.

$\mathrm{V}, \mathrm{B}$ denotes the paired dataset for volume-planimetric area.

Table 10. Parameters for computing the F-statistic to compare the best-fit regression models with combined and individual datasets.

\begin{tabular}{|c|c|c|c|c|}
\hline \multicolumn{5}{|c|}{ Combined datasets (null model) } \\
\hline Rock avalanche & Lahar & Debris flow & Residual sum of squares, $\boldsymbol{S S}_{\text {null }}$ & Number of samples, $n_{1}+n_{2}$ \\
\hline $\mathrm{X}$ & & \multirow{3}{*}{$\mathrm{X}$} & $V, A \quad 12.81$ & 63 \\
\hline \multirow{3}{*}{$\mathrm{X}$} & \multirow{2}{*}{$\mathrm{X}$} & & 7.410 & 31 \\
\hline & & & $V, B \quad 46.09$ & 169 \\
\hline & $\mathrm{X}$ & $\mathrm{X}$ & $V, A \quad 11.18$ & 68 \\
\hline Rock avalanche & Lahar & Debris flow & Residual sum of squares, $S_{\text {regr }}$ & Number of samples, $n$ \\
\hline \multirow{3}{*}{$X$} & \multirow{3}{*}{$\mathrm{X}$} & \multirow{3}{*}{$\mathrm{X}$} & 2.274 & 13 \\
\hline & & & 26.77 & 142 \\
\hline & & & 1.967 & 18 \\
\hline
\end{tabular}

$\mathrm{V}$, A denotes the paired dataset for volume-cross sectional area.

$\mathrm{V}, \mathrm{B}$ denotes the paired dataset for volume-planimetric area. 
considered separate because the physical processes they represent typically occur at different scales. (Nonvolcanic debris flows generally do not achieve volumes greater than $10^{6} \mathrm{~m}^{3}$ because the terrain in which they initiate, transport, and deposit does not provide adequate relief and erodible material to produce large flows. Lahars entrain and deposit material across large distances and through great relief where ample unconsolidated material is available, and they are, therefore, able to achieve greater volumes.) The equations for inundated planimetric area have distinct y-intercepts based on F-test results, and therefore, separate equations for predicting inundated planimetric areas are warranted. On the other hand, the intercepts for the cross-sectional area-inundation equations are statistically indistinguishable. Therefore, although lahars and debris flows can have widely differing flow volumes (ranging from 10 to $10^{10} \mathrm{~m}^{3}$ ), some aspects of their behavior probably are similar, as discussed below.

The third comparison is between debris flows and rock avalanches (fig. 10, table 13). For this case, the y-intercepts for the planimetric inundation equations are known to be similar (see the discussion of $\alpha$-values in the previous section). Thus, the F-tests indicate that there is ambiguity in differentiating the planimetric-area inundation equations. Moreover, the F-tests show that, for prediction of cross-sectional area, the difference between the debris-flow equations and rockavalanche equations is not statistically significant. Therefore, areas inundated by modest-sized debris flows and by great rock avalanches exhibit statistically indistinguishable dependencies on flow volume.

Table 11. F-test comparison between the combined dataset and individual datasets for rock avalanches and lahars.

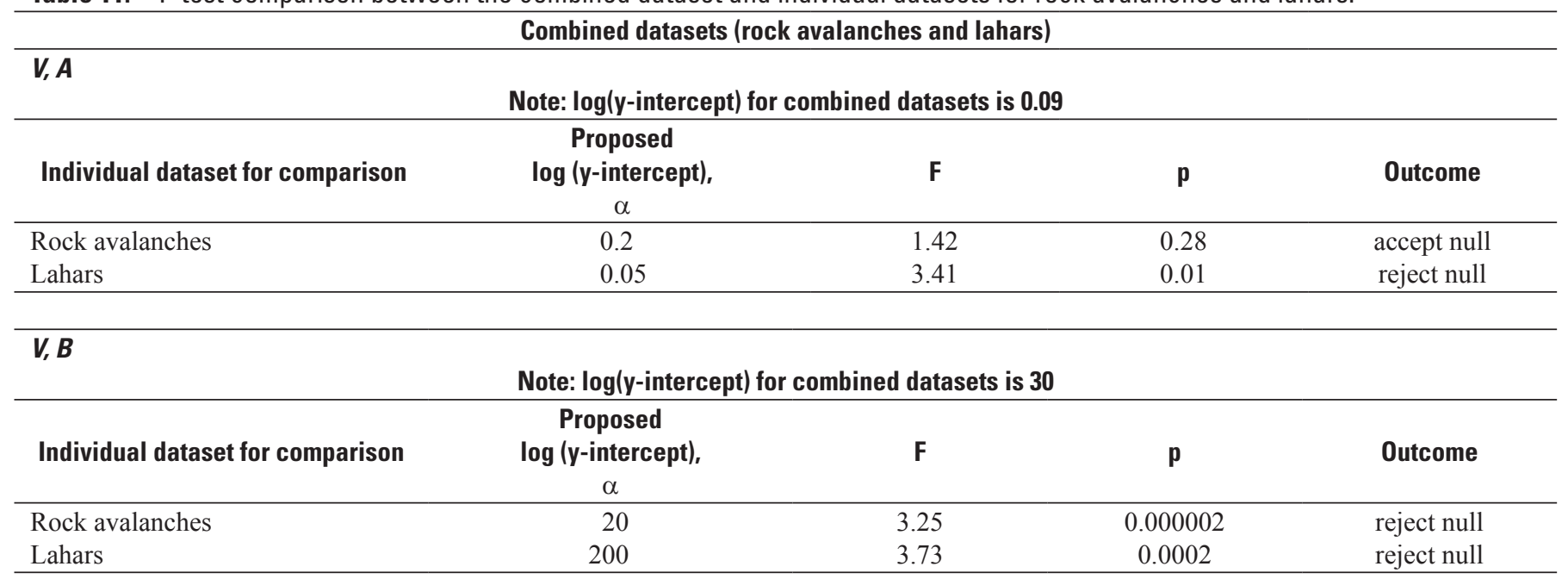

Table 12. F-test comparison between the combined dataset and the individual datasets for debris flows and lahars.

\begin{tabular}{|c|c|c|c|c|}
\hline \multicolumn{5}{|c|}{ Combined datasets (debris flows and lahars) } \\
\hline$V, A$ & & & & \\
\hline \multicolumn{5}{|c|}{ Note: $\log (y$-intercept) for combined datasets is $\mathbf{0 . 0 8}$} \\
\hline $\begin{array}{l}\text { Individual dataset for } \\
\text { comparison }\end{array}$ & $\begin{array}{c}\text { Proposed } \\
\log (y \text {-intercept), } \alpha\end{array}$ & $\mathbf{F}$ & $\mathbf{p}$ & Outcome \\
\hline Debris Flows & 0.1 & 1.00 & 0.48 & accept null \\
\hline Lahars & 0.05 & 1.77 & 0.10 & accept null \\
\hline \multicolumn{5}{|l|}{$V, B$} \\
\hline \multicolumn{5}{|c|}{ Note: $\log (y$-intercept) for combined datasets is $\mathbf{4 0}$} \\
\hline $\begin{array}{l}\text { Individual dataset for } \\
\text { comparison }\end{array}$ & $\begin{array}{c}\text { Proposed } \\
\log (y \text {-intercept) , } \alpha\end{array}$ & $\mathbf{F}$ & $\mathbf{p}$ & Outcome \\
\hline Debris Flows & 20 & 5.68 & 0.0000003 & reject null \\
\hline Lahars & 200 & 5.25 & 0.00002 & reject null \\
\hline
\end{tabular}


Table 13. F-test comparison between the combined dataset and the individual datasets for rock avalanches and debris flows.

\begin{tabular}{|c|c|c|c|c|}
\hline \multicolumn{5}{|c|}{ Combined Datasets (debris flows and rock avalanches) } \\
\hline$V, A$ & & & & \\
\hline \multicolumn{5}{|c|}{ Note: $\log (y$-intercept) for combined datasets is $\mathbf{0 . 1}$} \\
\hline $\begin{array}{l}\text { Individual dataset for } \\
\text { comparison }\end{array}$ & $\begin{array}{c}\text { Proposed } \\
\log (y \text {-intercept }), \alpha \\
\end{array}$ & $\mathbf{F}$ & $\mathbf{p}$ & Outcome \\
\hline Rock avalanches & 0.2 & 1.00 & 0.54 & accept null \\
\hline Debris flows & 0.1 & 1.24 & 0.28 & accept null \\
\hline \multicolumn{5}{|l|}{$V, B$} \\
\hline \multicolumn{5}{|c|}{ Note: $\log (y$-intercept) for combined datasets is $\mathbf{2 0}$} \\
\hline $\begin{array}{l}\text { Individual Dataset for } \\
\text { Comparison }\end{array}$ & $\begin{array}{c}\text { Proposed } \\
\log (y \text {-intercept }), \alpha\end{array}$ & $\mathbf{F}$ & p & Outcome \\
\hline Rock avalanches & 20 & 0.54 & 0.99 & accept null \\
\hline Debris flows & 20 & 1.85 & 0.01 & reject null \\
\hline
\end{tabular}

Table 14. F-test comparison between combined rock avalanche and lahar datasets and the listed individual datasets for a best-fit regression slope (non-2/3). Statistical results are the same as the case where the regression slope is forced to $2 / 3$.

\begin{tabular}{lccc}
\hline $\boldsymbol{V}, \boldsymbol{A}$ & $\mathbf{F}$ & $\mathbf{p}$ & $\mathbf{0}$ \\
\hline Rock avalanches & 1.19 & 0.40 & accept null \\
Lahars & 2.96 & & \\
\hline & & $\mathbf{r}$ & \\
\hline $\boldsymbol{V}, \boldsymbol{B}$ & $\mathbf{F}$ & $\mathbf{p}$ & $\mathbf{0}$ \\
\hline Rock avalanchect null & 3.58 & 0.0000003 & reject null \\
Lahars & 3.98 & 0.0001 & reject null \\
\hline
\end{tabular}

Table 15. F-test comparison between combined debris flow and lahar datasets and the listed individual datasets for a best-fit regression slope (non-2/3). Statistical results are the same as the case where the regression slope is forced to $2 / 3$.

\begin{tabular}{lccc}
\hline $\boldsymbol{V}, \boldsymbol{A}$ & $\mathbf{F}$ & $\mathbf{p}$ & $\mathbf{0 u t c o m e}$ \\
\hline Debris flows & 0.61 & 0.88 & accept null \\
Lahars & 1.38 & 0.25 & \\
\hline & & $\mathbf{p}$ & accept null \\
\hline $\boldsymbol{V} \boldsymbol{B}$ & $\mathbf{F}$ & 0.008 & Outcome \\
\hline Debris flows & 2.28 & reject null \\
Lahars & 2.50 & 0.009 & reject null \\
\hline
\end{tabular}

Table 16. F-test comparison between combined rock avalanche and debris flow datasets and the listed individual datasets for a best-fit regression slope (non-2/3). Statistical results are the same as the case where the regression slope is forced to $2 / 3$.

\begin{tabular}{lccc}
\hline $\boldsymbol{V}, \boldsymbol{A}$ & $\mathbf{F}$ & $\mathbf{p}$ & $\mathbf{0 u t c o m e}$ \\
\hline Rock avalanche & 0.91 & 0.62 & accept null \\
Debris flows & 1.44 & 0.17 & accept null \\
\hline & & $\mathbf{F}$ & $\mathbf{0 u t c o m e}$ \\
\hline $\boldsymbol{V}, \boldsymbol{B}$ & $\mathbf{F}$ & 0.99 & accept null \\
\hline Rock avalanche & 0.53 & 0.01 & reject null \\
Debris flows & 1.88 & & r
\end{tabular}




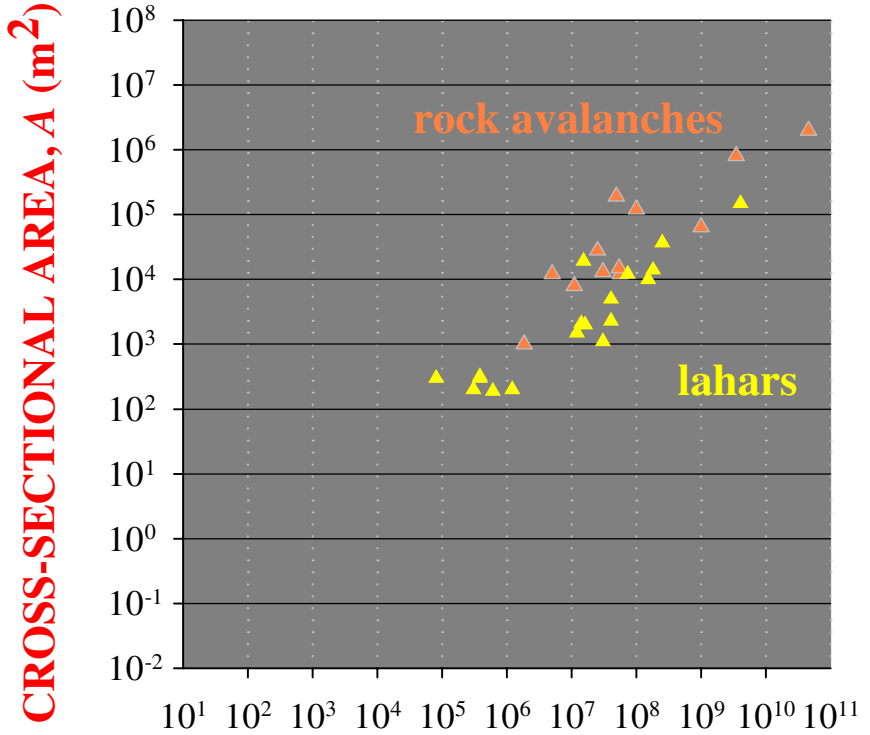

FLOW VOLUME, $V\left(\mathrm{~m}^{3}\right)$

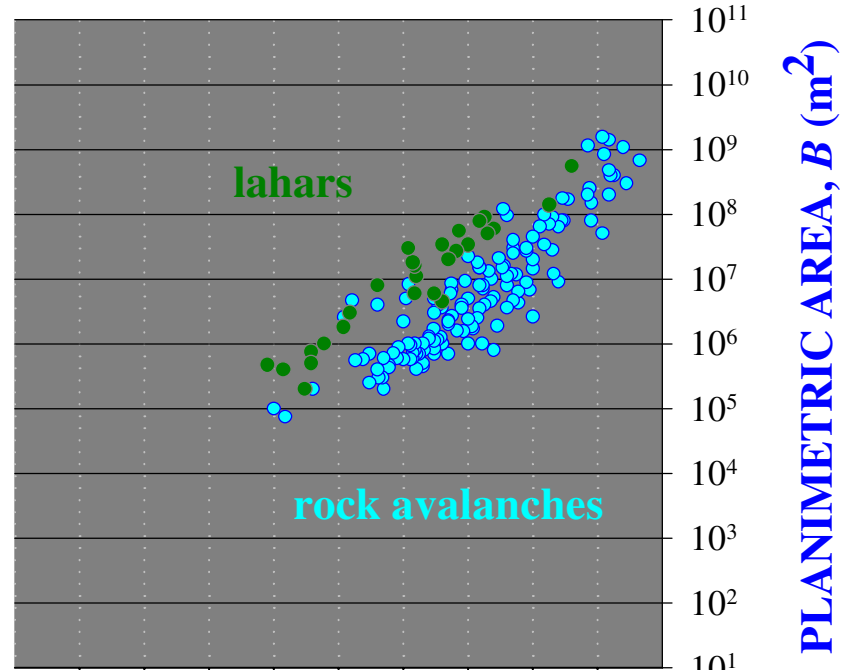

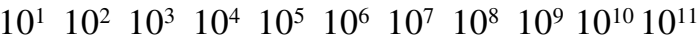

FLOW VOLUME, $V\left(\mathrm{~m}^{3}\right)$

Figure 8. Rock-avalanche and lahar data used to compute statistics as a combined dataset (see table 11). On the cross-sectional area plot, the data for rock avalanches and lahars are not obviously separated. On the planimetric-area plot, the data trends are visibly separate.

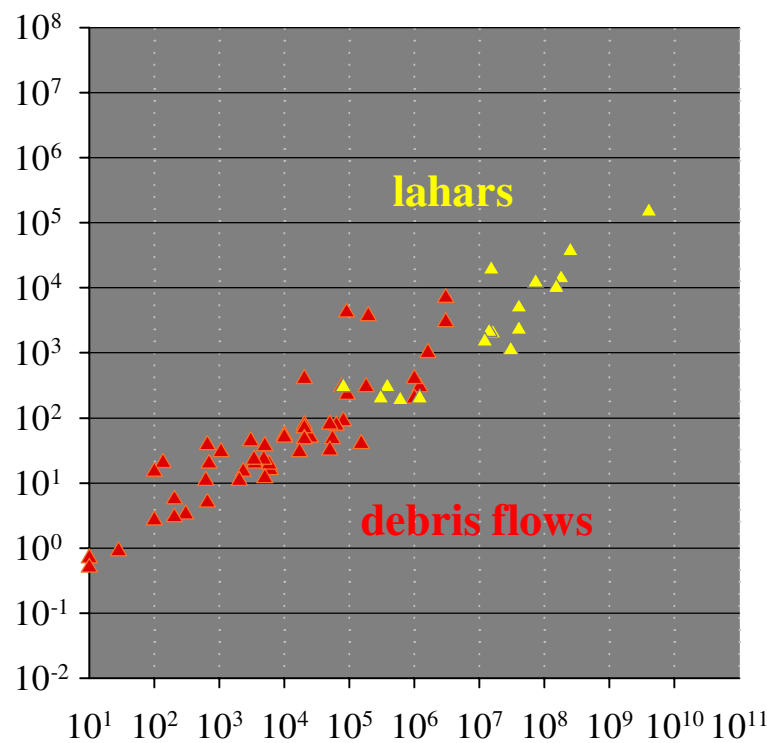

FLOW VOLUME, $V\left(\mathrm{~m}^{3}\right)$

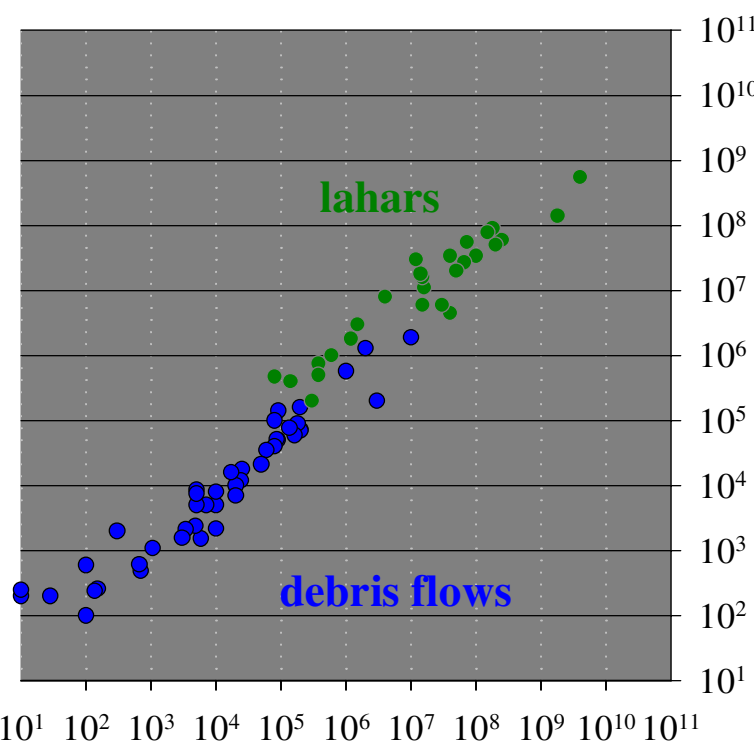

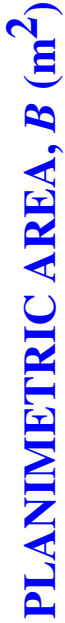

Figure 9. Debris-flow and lahar data used to compute statistics as a combined dataset (see table 12). On the cross-sectional area plot, the data for rock avalanches and lahars generally occupy different potions of the flow volume range, but the data trends are not visibly separate. On the planimetric-area plot, the data trends appear somewhat separate. 


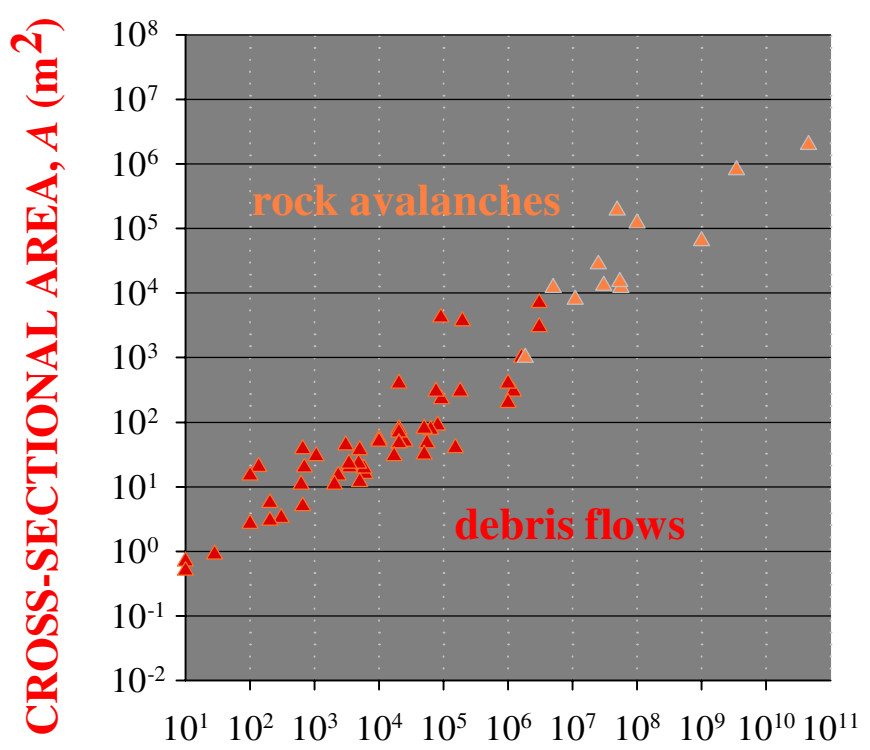

FLOW VOLUME, $V\left(\mathbf{m}^{3}\right)$

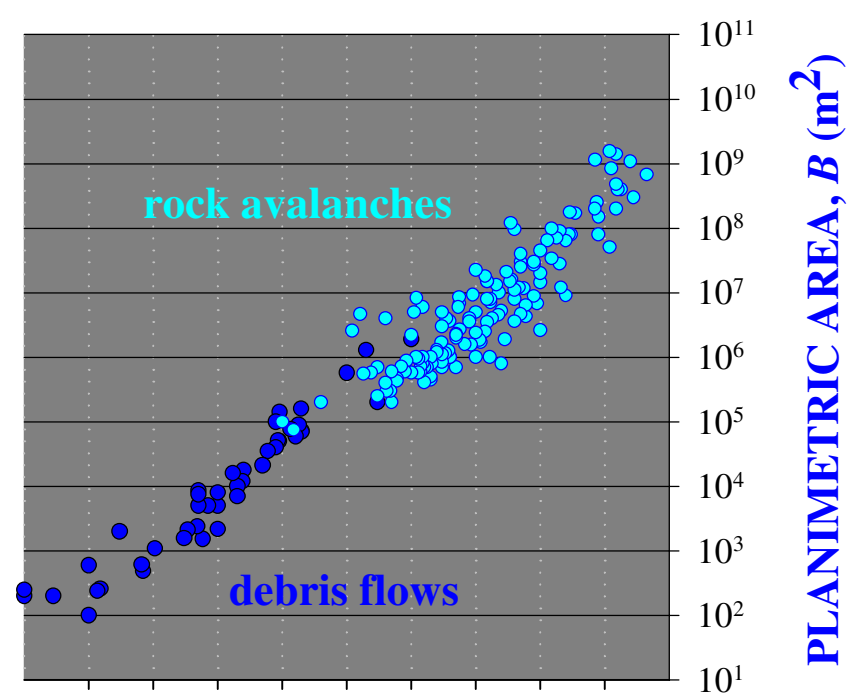

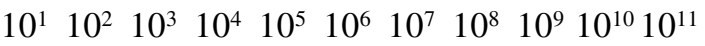

FLOW VOLUME, $V\left(\mathbf{m}^{3}\right)$

Figure 10. Debris-flow and rock-avalanche data used to compute statistics as a combined dataset (see table 13). On the crosssectional area plot, the data for rock avalanches and debris flows occupy different potions of the flow-volume range, but the data trends are not visibly separate. On the planimetric-area plot, the data trends appear somewhat separate.

\section{Error and Uncertainty in Calibrated Prediction Equations}

The standard errors and predictive uncertainties of the 2/3-slope models with best-fit calibrated $\alpha$-coefficients (table 6) have important ramifications for how the equations are interpreted and used. The standard errors, $\sigma$, of these models (tables 1-4) characterize the variability of behavior exhibited by past flows, and the 99-percent confidence interval curves for prediction (figs. 11-13) characterize the uncertainties of predicting areas inundated by future flows if volume is known with certainty (cf. Helsel and Hirsh, 1992). The factors of error $\left(10^{\sigma}\right)$ for predicting inundation areas $(A, B)$ for rock avalanches $\left(10^{\sigma}=2.7,2.8\right)$ are somewhat larger than the factors of error for debris flows $\left(10^{\sigma}=2.7,2.1\right)$ and lahars $\left(10^{\sigma}=2.2,1.9\right)$.

As an example of the effect of uncertainty, we considered prediction of planimetric areas inundated by debris flows. Taken alone, the inundation-area equation predicts that a debris flow of $10^{5} \mathrm{~m}^{3}$ would inundate a planimetric area of $43,000 \mathrm{~m}^{2}$. The 99-percent confidence interval for prediction of the inundation area (outer set of curves, fig. 12) for the same flow volume, however, indicates a wide range of possible inundation areas, between 6,000 and $300,000 \mathrm{~m}^{2}$. At the 95-percent confidence level (not shown in figures) this range shrinks to between 10,000 and $200,000 \mathrm{~m}^{2}$, but the uncertainty remains considerable. The confidence intervals for prediction are great owing to the data scatter associated with diverse natural events, but if a lower degree of confidence can be tolerated, then the range of prediction uncertainty is reduced. We chose to stipulate a high degree of confidence (99-percent), resulting in portrayal of wide confidence limits.

\section{Discussion and Interpretation of Predictive Equations}

Statistical results show that the power-law equations summarized in table 6 adequately relate inundation areas to flow volumes, and that power-law equations with a specified slope of $2 / 3$ are indistinguishable from best-fit power-law regression equations. Therefore, equations of the form Area $=\alpha$ Volume ${ }^{2 / 3}$ are adopted for purposes of hazard-zone delineation. Only one significant digit is used to specify the $\alpha$-coefficients in the predictive equations listed in table 6 ; greater precision is unwarranted given the uncertainties inherent in the predictive models.

Constant power-law exponents (constant slopes on loglog plots) in our predictive equations imply a fractal scaling, and such geometric fractals are said to be scale invariant (Peitgen and others, 1992). Thus, for a wide range of flow volumes, inundated areas will appear similar when portrayed on maps of any scale. Clearly, however, there is a practical limit below which the power-law equations do not apply. For example, as volume falls below the smallest observed flow volume $\left(10^{1} \mathrm{~m}^{3}\right)$ and approaches zero, we should not expect the equations to apply. This is an important consideration because 

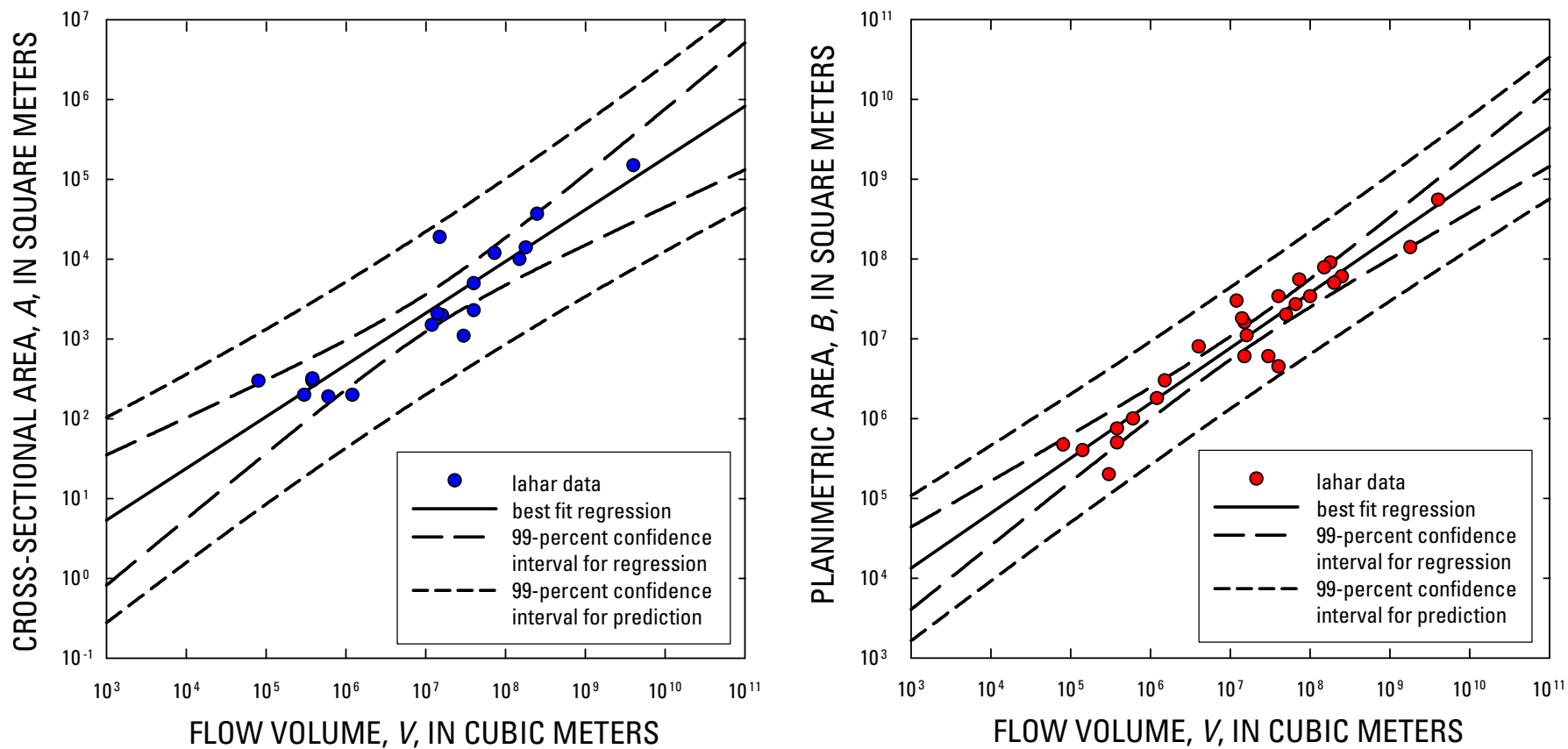

Figure 11. Lahar data and best-fit regression line (solid) with 99-percent confidence interval for regression (inner pair of dashed curves) and 99-percent confidence interval for prediction (outer pair of dashed curves; computed following Helsel and Hirsch, 1992) after Iverson and others (1998). Note that Iverson and others used 95-percent confidence intervals.
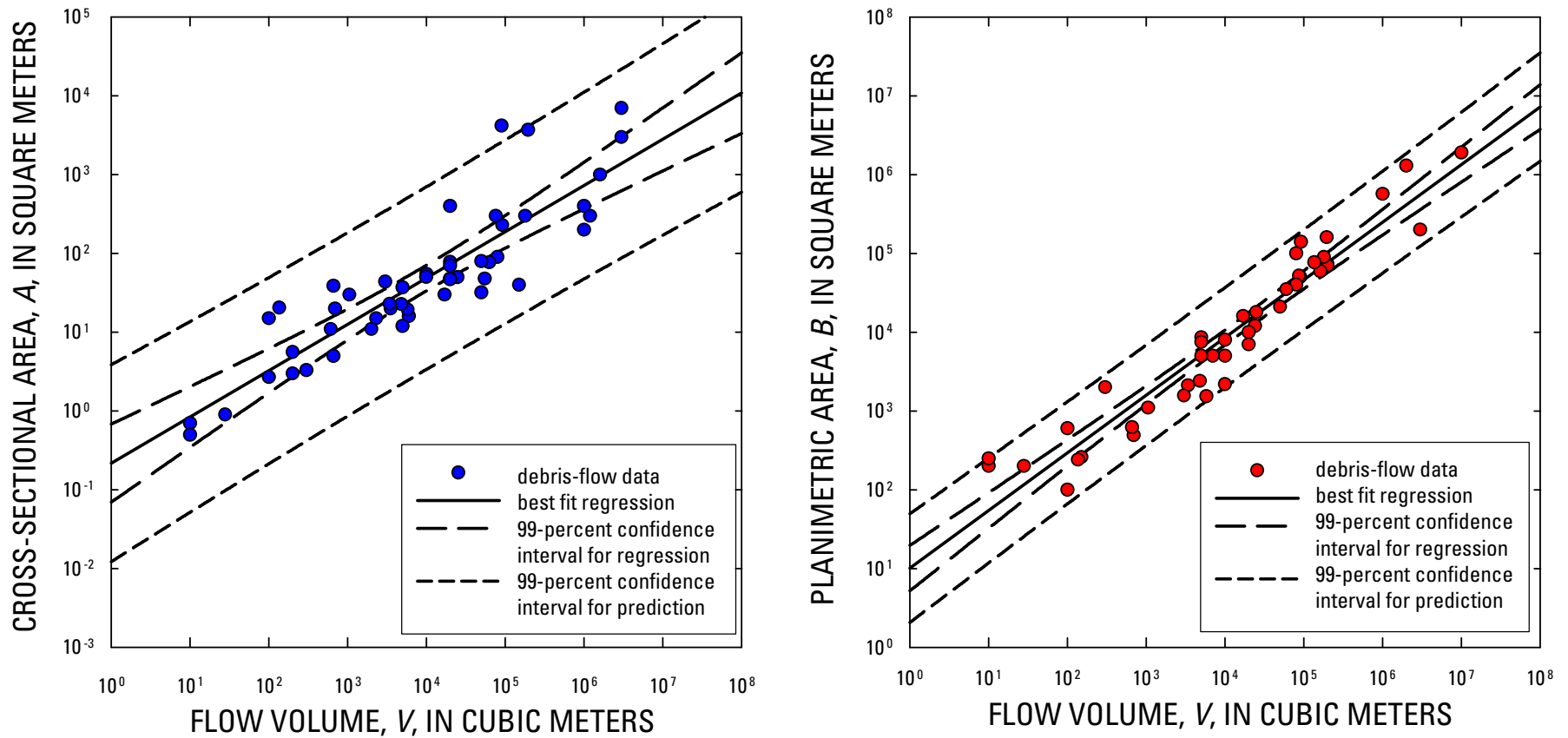

Figure 12. Debris-flow data and best-fit regression line (solid) with 99-percent confidence interval for regression (inner pair of dashed curves) and 99-percent confidence interval for prediction (outer pair of dashed curves; computed following Helsel and Hirsch, 1992). 

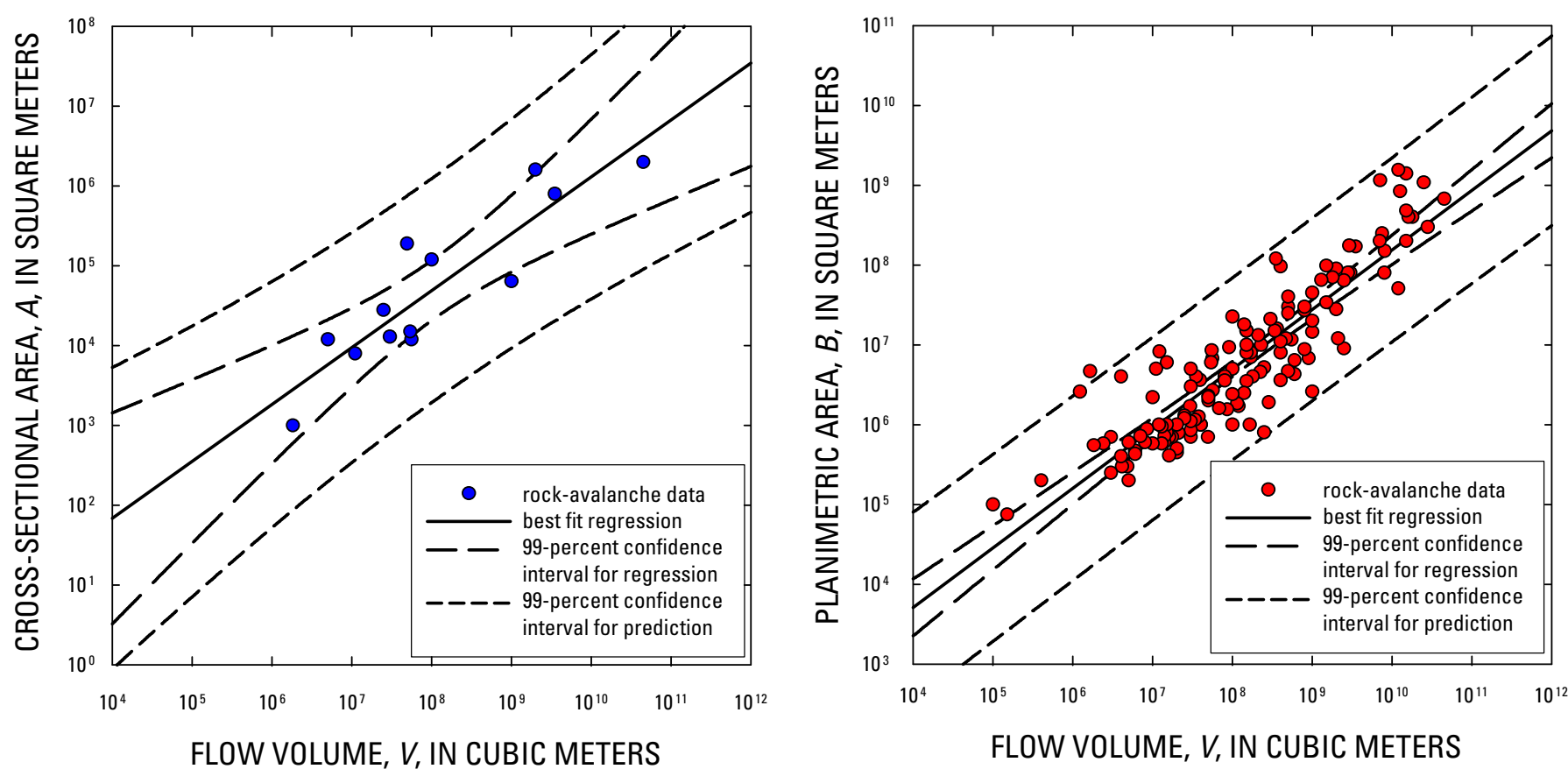

Figure 13. Rock-avalanche data and best-fit regression line (solid) with 99-percent confidence interval for regression (inner pair of dashed curves) and 99-percent confidence interval for prediction (outer pair of dashed curves; computed following Helsel and Hirsch, 1992).

log-transformed versions of the equations would imply a non-zero y-intercept where volume is equal to zero, and this is physically impossible. This observation doesn't imply that the equations do not hold true, but that they operate across a wide but finite range of scales.

According to the coefficients of the calibrated 2/3-powerlaw models (table 6), lahars typically inundate a planimetric area roughly ten times greater than do debris flows or rock avalanches of the same volume. Rock avalanches typically inundate valley cross-sectional areas four times greater than does a lahar of equal volume, and two times greater than a debris flow of equal volume. The relatively large cross-sections inundated by rock avalanches imply the existence of a relatively resistive, bulky cross-sectional surge front, whereas debris flows flow more fluidly, and lahars flow more fluidly still. The explanation for these differences probably lies in the typical compositions and typical topographies traversed by each type of flow (for example, Vallance and Scott, 1997). However, physical or geological interpretations of differing $\alpha$ coefficients in our power-law equations must be tempered in view of statistical results that show that differing coefficients may not be truly distinct. Statistical comparison of the calibrated equations for inundated cross-sectional areas ( $A=0.05 \mathrm{~V}^{2 / 3}, A=0.1 \mathrm{~V}^{2 / 3}$ and $A=0.2 V^{2 / 3}$ for lahars, debris flows, and rock avalanches, respectively) shows that the $\alpha$-coefficient values $(0.05,0.1$, and 0.2$)$ are not distinct at the 99-percent confidence level. This lack of distinction implies that there is considerable overlap in the physical behavior of these three types of flows, at least insofar as behavior determines cross-sectional inundation. For inundation-prediction purposes, we gained some resolving power by retaining distinct equations for the three types of flows, and this is the course we adopted in practice.

With respect to equations for prediction of planimetric inundation areas, however, there is a clear statistical distinction between the lahar equation $B=200 V^{2 / 3}$ and the equation that applies to both debris flows and rock avalanches, $B=$ $20 \mathrm{~V}^{2 / 3}$. Separate inundation equations should be applied for separate types of flows.

The development and comparison of the inundation-area equations listed in table 6 is the lack of clear statistical distinction between the equations that apply for debris flows and the equations that apply for rock avalanches. When considering this statistical similarity, however, it must be borne in mind that the rock-avalanche data included in the dataset apply to events with volumes that are, on average, several orders of magnitude larger than the volumes of debris flows included in the data set. In terms of inundation patterns, large rock avalanches tend to appear like small, nonvolcanic debris flows viewed at a proportionally smaller scale. The reasons for this geometric similarity may be severalfold. Nonvolcanic debris flows (with volumes generally less than $10^{6} \mathrm{~m}^{3}$ ) commonly 
entrain large boulders, logs, and other coarse debris that concentrate at the flow front and produce a high-friction zone there (Iverson, 1997). In many cases, individual clasts at the flow front have dimensions comparable to the flow thickness or the flow width. Nonvolcanic debris flows are commonly channeled into narrow stream courses in finely dissected terrain, and a large degree of form drag thereby retards flow runout. In this sense, the fronts of nonvolcanic debris flows may behave much like the fronts of large rock avalanches that surmount small-terrain obstacles and respond only to the largest features of topography. Much evidence exists to suggest that large rock avalanches are, to some degree, fluidized at their bases, facilitating distal runout (for example, Legros, 2002). Although there is still controversy concerning the exact mechanism by which this fluidization can occur in the absence of saturation with water, there is no doubt that large rock avalanches can to some extent behave like much smaller, liquefied debris flows. Thus, the similarity in power-law inundation equations for nonvolcanic debris flows and much larger rock avalanches is perhaps unsurprising.

\section{Debris-Flow Hazard Delineation by using DEMs and GIS}

As an example of application of our inundation-area equations to hazard-zone delineation, we considered an area in the south-central Oregon Coast Range where significant hazard from debris flows exists (fig. 14). Creating a hazard zone map requires (1) obtaining topographic data of adequate grid cell size, accuracy, and precision to represent the size of the anticipated events and of sufficient extent to cover the area of interest, (2) identifying potential debris-flow source areas, (3) selecting appropriate potential flow volumes, (4) using inundation-area equations to calculate the predicted Aand B-values corresponding to the selected V-values, and (5) computing and displaying the delineated planimetric areas as nested hazard zones that depict uncertainty and relative levels of hazard posed by the suite of potential flows. Automation of the computations and display process is important, especially for high-resolution data covering large areas, and it also ensures reproducibility.

As a platform for automation, we use GIS-based software, LAHARZ, written in the ArcInfo Macro Language (AML) (Schilling, 1998). This software has been used to construct dozens of volcano hazard assessment maps around the world (for example, Schilling and others, 2001; Vallance and others, 2001; Scott and others, 2001; Gardner and others, 2004) and also used and compared to other methods of runout prediction (for example, Sheridan and others, 1999; Haapala and others, 2005; Sorenson, 2003). Below we summarize the data requirements and programming modifications necessary to adapt LAHARZ for application to nonvolcanic debris flows.

\section{Data Input}

Data input for LAHARZ includes a range of postulated flow volumes, digital topographic data, a suite of flow-path data derived from the topography, and identification of source areas where debris flows may originate. Specification of appropriate flow volumes generally requires an estimate of available surficial material on slopes or within channels, as well as a historical perspective of the range of volumes that a given geographic area has produced. For example, the Coast Range in Oregon would not likely produce a flow with a volume of $1 \mathrm{~km}^{3}$ because the topographic relief in prospective source areas is typically of the order of $100 \mathrm{~m}$, and therefore, a maximum credible flow volume might be $0.001 \mathrm{~km}^{3}$. The range of postulated flow volumes should span 2 or 3 orders of magnitude to encompass a range of probability of occurrence. Volumes ranging from smaller (more frequent) to larger (less frequent) depict areas of decreasing inundation hazard because areas that are likely to be inundated more frequently have greater hazard associated with them.

Selecting the increment between successive flow volumes used to forecast hazards can be done so as to mirror the intrinsic statistical error of the models. For debris flows the standard error, $\sigma$, of the calibrated power-law models (tables $6-9$ ) is $<0.5$ (ranging from 0.32 to 0.45 ), such that a conserva-

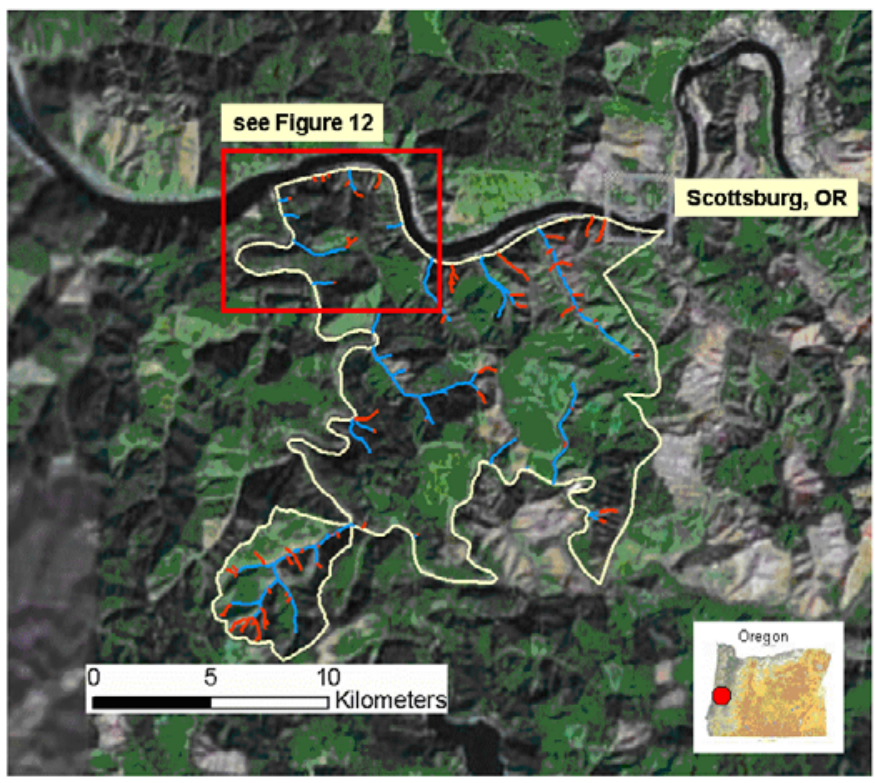

Figure 14. Aerial photograph (Google Earth) of the Scottsburg, Oregon, area. The dark ribbon is the Umpqua River. Mapped recent debris-flow paths are in red, perennial streams are in blue, and the yellow line denotes the extent of the Oregon Department of Forestry's research area (Robinson and others, 1999). 
tive factor of error $\left(10^{\sigma}\right)$ is half an order of magnitude $\left(10^{0.5}\right)$. Deliberate use of such a flow-volume increment is a technique that effectively enables the display of error bars in the form of nested hazard zones (Iverson and others, 1998). Depicting successive hazard zones in a nested fashion implies that any given flow volume produces a unique, predicted inundation area \pm the area of the closest larger and smaller nested-hazard zones.

The demand for resolution and precision of topographic data depends on the volumes of the flow events that are postulated. For example, the digital elevation model (DEM) used in the lahar hazard assessment at Mount Rainier, Washington, has $62.5-\mathrm{m}$ grid cells for a map spanning much of western Washington (Iverson and others, 1998). This resolution is adequate for large-volume lahars $\left(>10^{7} \mathrm{~m}^{3}\right)$ that inundate broad areas, as potential inundation areas are much greater than the size of the individual grid cells. Small-volume debris flows $\left(<10^{5} \mathrm{~m}^{3}\right)$ may have flow widths less than $10 \mathrm{~m}$ and, therefore, require cell-size resolution and accuracy of roughly a few meters.

The main LAHARZ algorithm computes hazard zones downslope or downstream from source areas, but these areas must be identified by some independent means. Source-area identification in highly dissected topography is particularly challenging because many prospective source areas may exist. Our modified version of LAHARZ addresses the source-area problem by using a combination of three criteria appropriate for identifying debris-flow initiation sites in the Oregon Coast Range, our target for model application:

(1) A specified minimum contributing-upslope source area must exist, analogous to contributing areas commonly used to evaluate surface-water runoff in hydrologic models. In our implementation, the default minimum contributing source area for debris flows is $10^{3} \mathrm{~m}^{2}$. This value derives from evidence of initial failure scars and the onset of debris-flow inundation in site-specific reports for the Coast Range of southwestern Oregon (for example, Harvey and Squier, unpub. data, 1998).

(2) A specified minimum slope angle must exist within the source area or along the computer-generated thalweg fed by the source area. This criterion is based on the observation that debris flows generally initiate on slopes $\theta>30$ degrees (Iverson and others, 1997), and we used 30 degrees as the default minimum slope.

(3) Slopes must be uniformly steep in the vicinity of a prospective initiation site. Here, uniformly steep is defined as 95 -percent of grid cells, exceeding 30 degrees, in a $100-\mathrm{m}^{2}$ area centered on a prospective initiation cell. This criterion excludes small patches of steep ground that are unlikely to produce slope failures of significant size.

Criteria 1 and 2 serve to identify many potential initiation cells in a DEM, and criterion 3 limits the number of cells that define the starting points for debris-flow inundation. Criterion 3 also serves to limit the potential for DEM errors to lead to false identifications of sufficiently steep ground. The specifications listed here are default settings for our modified LAHARZ program, but they may be adjusted after a sensitivity analysis is performed for any particular study area.
Used in combination, the initiation criteria 1-3 are somewhat similar to the criteria used to forecast sites of shallow-landslide initiation in spatially distributed models, such as SHALSTAB (Montgomery and Dietrich, 1994). Like the criteria in SHALSTAB, our criteria are intended to identify all prospective source areas in a drainage basin simultaneously. This simultaneous delineation does not imply that all source areas will generate debris flows. Rather, it implies that many source areas have equal probabilities of spawning debris flows, thereby leading to simultaneous delineation of many possible inundation paths downstream. In contrast to the criteria used in SHALSTAB, our simple flow-initiation criteria are not intended to emulate physical processes, but instead are entirely empirical - although they do exploit the common observation that slope angle and upslope contributing area are important morphometric parameters in determining flowinitiation sites.

\section{Application Area for Debris-Flow Hazard Mapping-Scottsburg, Oregon}

\section{History of the Scottsburg Area}

In the south-central Oregon Coast Range (fig. 14), the town of Scottsburg and the Rock Creek-Hubbard Creek watershed (also known as Stump Acres) in southern Douglas County, Oregon, became infamous when two debris flows caused five fatalities between November 17 and 19, 1996. The deaths were the result of debris flows inundating a home, overtaking a pedestrian, and pushing a car off the road (The Oregonian, 1996; Mapes and Tims, 1996; Harvey and Squier, unpub. data, 1998). Highway 38 was blocked at multiple locations by debris flows that inundated the road, and many more debris flows occurred in the vicinity that winter season (fig. 14).

\section{Topography and Geology}

The map area shown in fig. $15\left(\sim 5 \mathrm{~km}^{2}\right)$ is characterized by narrow, dissected valleys and sharp ridges, and the elevations within this area range from $\sim 3$ to 390 meters msl (above mean sea level). Several unnamed perennial streams flow along lower portions of tributary valleys feeding the Umpqua River. The average and maximum slopes for the map area are 35 degrees and 77 degrees, respectively, if flat areas (river and roads) are excluded from consideration. These hillslopes are exceedingly steep, even by Coast Range standards.

The entire map area is underlain by the Tyee Formation, a late Eocene, eastward dipping, rhythmically bedded sandstone and siltstone (Baldwin, 1961). The weakly consolidated bedrock is easily weathered and eroded, and it yields a succession of highly dissected ridges and small valleys. Where the sandstone dominates, ridgelines are sharp; and where the siltstone dominates, ridges are moderately rounded. Based 


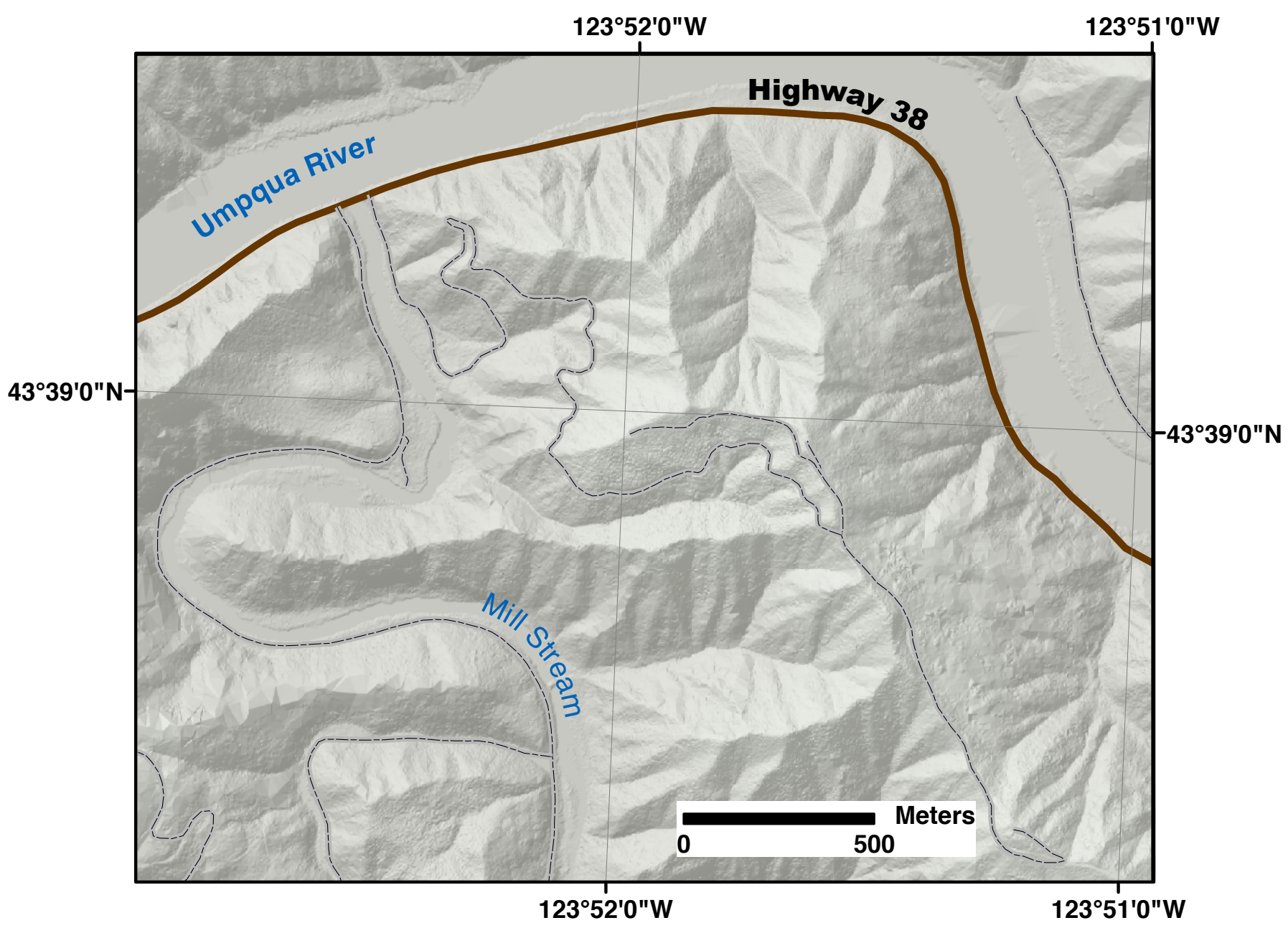

Figure 15. Shaded-relief map with highways and logging roads for the study area west of the town of Scottsburg in the central Coast Range of Oregon, at about 40 river kilometers from the coast.

on the Oregon Department of Forestry (ODF) Storm Impacts Study (Robinson and others, 1999) and the State of Oregon's Emergency Management Plan (OEMP, 2000), the highest debris flow/torrent hazard is within steeply sloped areas in the Tyee Formation (or similar sedimentary rocks) in Western Douglas, Coos, and Western Lane Counties. Most hillslopes that are steeper than 35 degrees can produce rapidly moving landslides, regardless of the underlying geologic unit. In designating high-risk areas, the ODF uses lower slope criteria in the Tyee Formation than for other geologic types (Robinson and others, 1999).

\section{Topographic Dataset-Acquisition and Description}

LIDAR (LIght Detection And Ranging) data acquired by ODF on November 9, 1997 for the area around Scottsburg were collected as part of a pilot study of damage assessment of the impacts of the torrential storms and debris flows of 1996. LIDAR technology uses an airborne laser transmitter and receiver coupled with GPS to map elevation profiles as the beam reflects off of surfaces such as tree canopy or bare earth. The elevation data are filtered to recover only bare-earth surface return times for the production of a 1-meter DEM with high resolution and accurate $\mathrm{X}, \mathrm{Y}$, and $\mathrm{Z}$ locations (for example, Schickler and Thorpe, 2001).

The topographic data were processed by ODF to minimize the effects of the dense tree canopy and derive elevations 
of the bare earth surface. The study area excludes regions of less dense data coverage around the periphery and therefore avoids coarse interpolation and false slopes. Within the DEM, however, some areas have relatively few elevation data due to dense tree coverage and fewer laser beams reaching the bare earth surface. The accuracy of the data in these areas is still high, but the elevation postings or resolution is reduced. The data points were used to create a TIN (triangulated irregular network), interpolated to a grid, and drainage enforced. Drainage enforcement is the filling of small topographic "sinks" or single cell depressions that inhibit continuous flow across a DEM. This enforces continuous drainage by raising the elevation of a single cell depression to the "pour" level of its neighbors using a standard GIS hydrologic function.

We used the TIN to generate a one-meter resolution DEM that has not been checked for 1-m accuracy, and thus, GIS products based on this topographic data should be interpreted as preliminary. Such resolution and accuracy, however, are needed for forecasting debris flow inundation where flow widths can be expected to be less than 10 meters.

\section{Background for Flow Volume Assessment for Scottsburg, Oregon}

Some constraints on applicable flow volumes are provided by the work of Ketcheson and Froelich (1978), who completed a landslide inventory in the Mapleton Ranger District of the Oregon Coast Range and found that initial volumes of slope failures ranged from 1.5 to $150 \mathrm{~m}^{3}$ for 104 events during a ten-year period (1966-1976). Although these initial volumes cannot be used to estimate maximum flow volume, they do provide a minimum flow-volume estimate.

Harvey and Squier (unpub. data, 1998) describe two debris flows that occurred within the same sub-basin as the Hwy 38 MP 13 event and describe evidence observed in aerial photographs for the Scottsburg area. In January 1990, a flow blocked the highway but did not enter the Umpqua River. In December 1992, a flow deposited 500-600 $\mathrm{m}^{3}$ of material on the highway. Aerial photographs taken in 1986 indicate recent

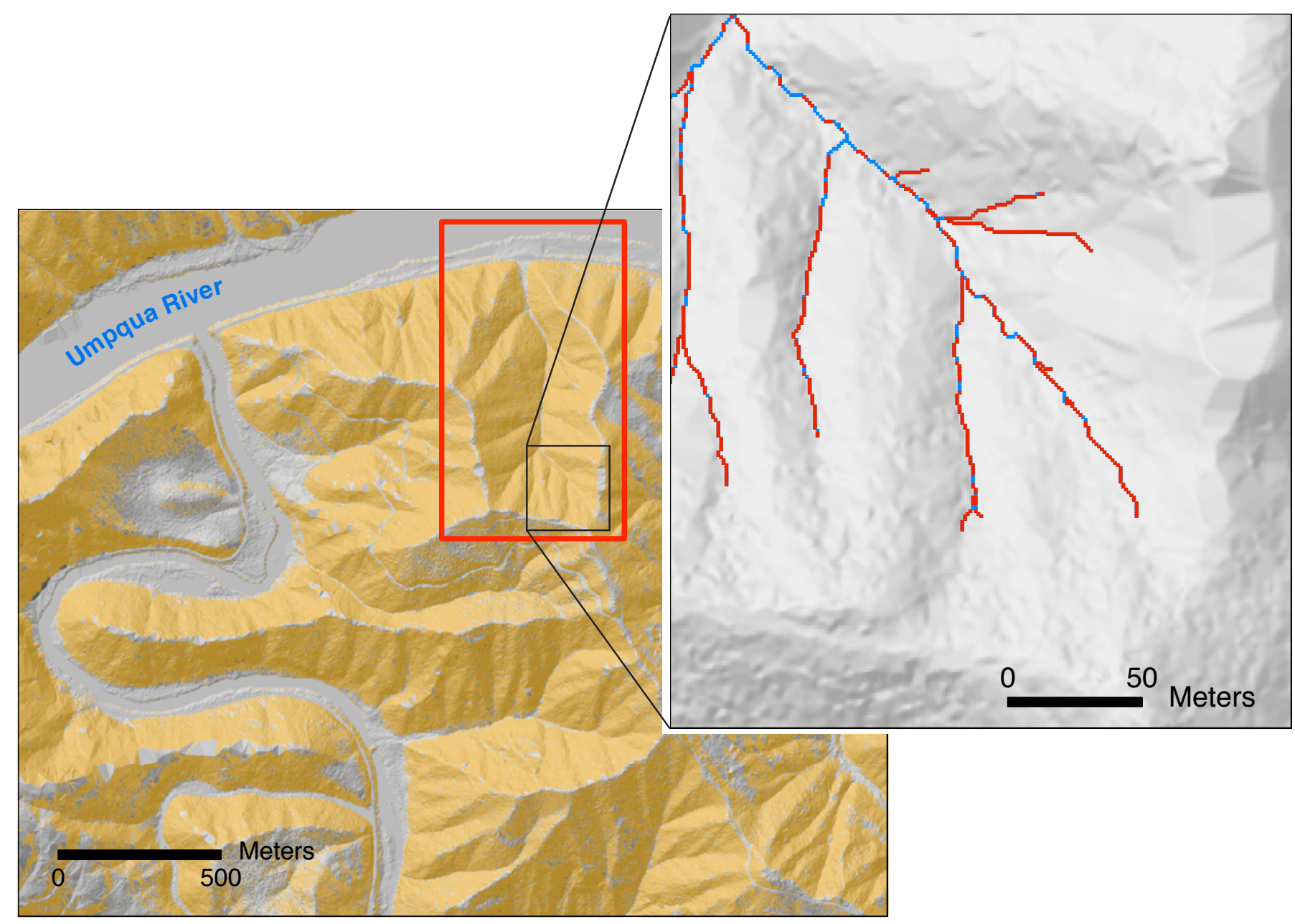

Figure 16. A, Shaded relief map constructed from a DEM, overlaid with orange where slopes exceed 30 degrees. The red box identifies the test basin where the modified LAHARZ program is applied. $B$, Example of locations (red cells) meeting initiation criteria along potential flow paths. 


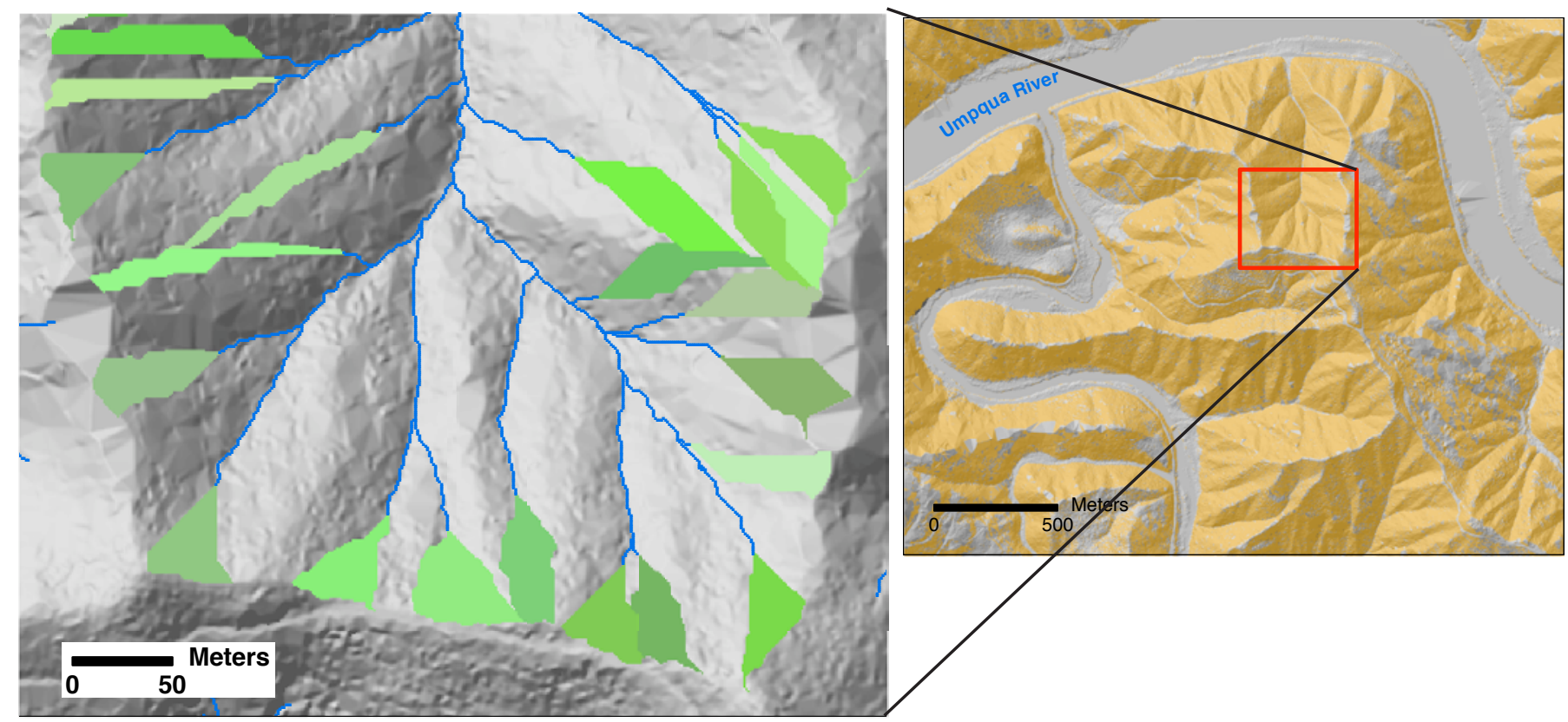

Figure 17. Shaded relief map of upper half of the test basin. Green-shaded polygons illustrate minimum contributing source areas that define the start of potential flow paths (blue). Flow paths are not perennial stream channels, but are the paths of steepest descent below an area of potential flow initiation. The image on the right shows the location of the upper half of the test basin (also fig. $16 \mathrm{~A}$ ) and the prevalence of steep slopes in the test basin as indicated by the presence of the orange overlay where slopes exceed 30 degrees.

debris flows in adjacent sub-basins also reached the highway. Aerial photographs from 1997 indicate that the fatal 1996 debris flow event was accompanied by multiple events within the upper reaches of the same subbasin and on adjacent slopes outside of the sub-basin. Many of those flows reached the highway. Total flow volumes, total runout lengths, and initiation locations were not recorded except for the single fatal event. The initiation site for the 1996 event was $\sim 45 \mathrm{~m}$ from the ridgeline (roughly sketched on a 1:2,000 scale map) and the runout length was about $400 \mathrm{~m}$.

Harvey and Squire (unpub. data, 1998) note that the November 1996 storm that produced the debris flows was preceded by 5 inches of precipitation in a 24-hour period and a total of 6 inches in 2 days. Harvey and Squier (unpub. data, 1998 ) indicate that this 2-day intensity of rain was the greatest in the past 48 years, and their recurrence analysis indicates that the storm event was a 50-year storm.

\section{LAHARZ Application}

One basin (red box, fig. 16A) was selected from the $5 \mathrm{~km}^{2}$-area of LIDAR coverage to run trial applications. One of the November 1996 debris flows emerged from this basin along the Umpqua River and pushed a traveling car off the road and into the Umpqua River channel.

Combining the three criteria for debris-flow initiation (see section on "Data Input") identifies hundreds of potential initiation sites within the study basin (fig. 16B). Each potential initiation cell, shown in red, represents one square meter. A total of 42 contributing source areas $\left(\geq 10^{3} \mathrm{~m}^{2}\right.$ each) were identified within the basin (shades of green, fig. 17).

The selected potential flow volumes are $10^{3}, 10^{3.5}, 10^{4}$, and $10^{4.5} \mathrm{~m}^{3}$ based on historic volumes for this region of the Coast Range and a rough estimate of available erodible material. Reports about the Scottsburg area suggest that several debris flows in the last two decades had volumes of $\sim 10^{3} \mathrm{~m}^{3}$. This minimum flow volume may represent events of roughly decadal frequency, and the larger flow volumes would represent less frequent events. In the study basin the longest potential flow path is $\sim 800$ meters and the entrainment swath might be 30-50 meters in width with one or two meters of erosion, yielding a conservative upper limit for flow volume $\sim 10^{4.5} \mathrm{~m}^{3}$.

For the selected series of flow volumes $\left(10^{3}, 10^{3.5}, 10^{4}\right.$, and $\left.10^{4.5} \mathrm{~m}^{3}\right)$, the inundation-area equations from table 6 , $A=0.1 \mathrm{~V}^{2 / 3}$ and $B=20 \mathrm{~V}^{2 / 3}$, predict cross-sectional areas $(A)$ of 10 , 22, 47, and $100 \mathrm{~m}^{2}$, and planimetric areas $(B)$ of 2,000; 4,300; 9,300; and 20,000 $\mathrm{m}^{2}$. With the aid of LAHARZ software, the four pairs of successively larger predicted $A$ - and $B$-values produce a set of four nested inundation zones. One set of inundation zones is produced for every initiation point (fig. 18A). Several amalgamated inundation-hazard zones are shown in figure $18 B$. Merging all the hazard zones from each of the initiation points creates coalesced hazard zones (fig. 19) for each postulated flow volume. The resulting debris-flow hazard map for the whole basin is shown in figures 19 and 20 . 


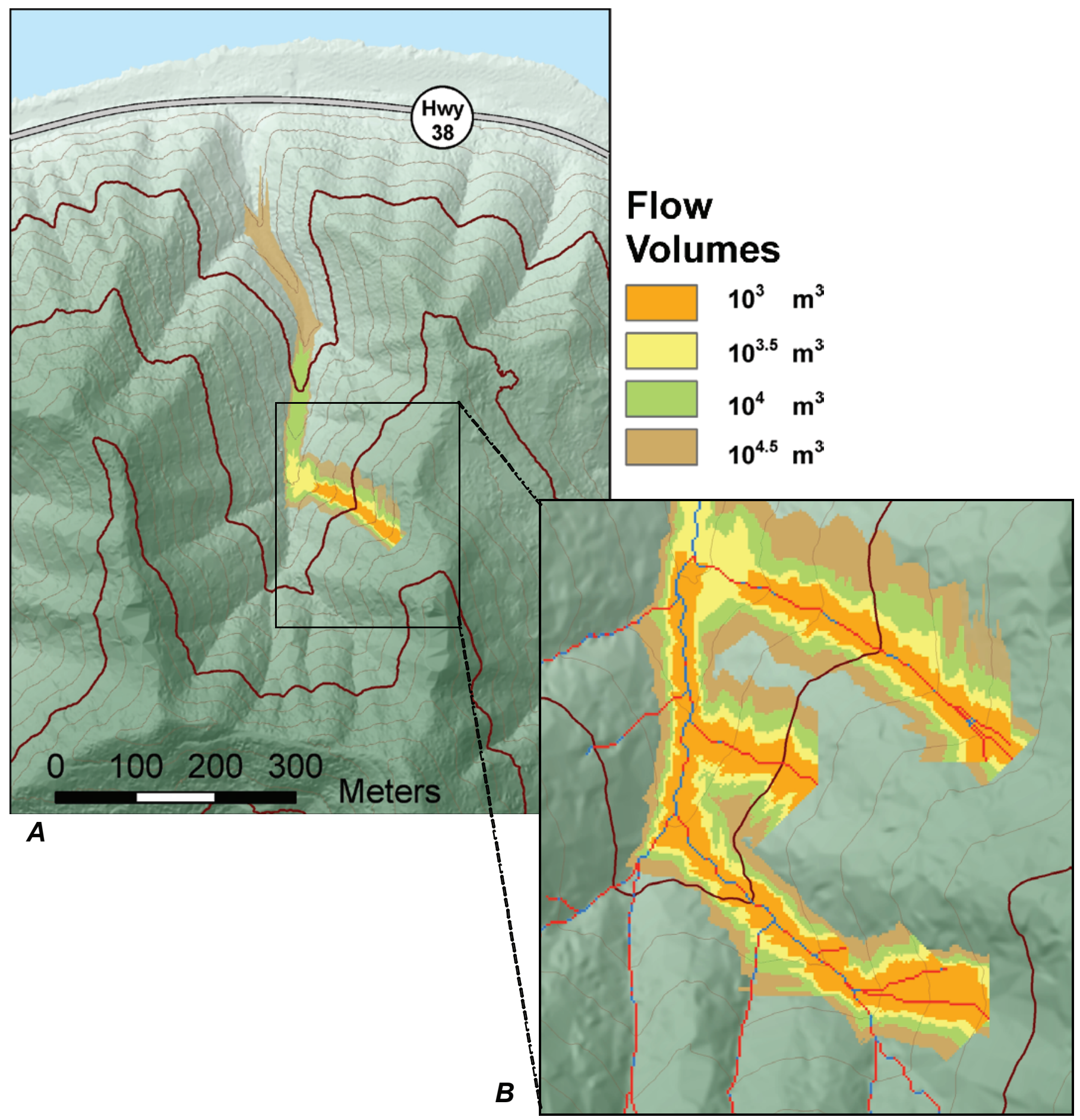

Figure 18. Examples of nested, inundation-hazard zones computed for four flow volumes (orange is $10^{3} \mathrm{~m}^{3}$, yellow is $10^{3.5} \mathrm{~m}^{3}$, green is $10^{4} \mathrm{~m}^{3}$, and brown is $\left.10^{4.5} \mathrm{~m}^{3}\right)$. $A$, Inundation-hazard zones computed downstream from a single initiation point within a flow path. $B$, Amalgamated inundation-hazard zones computed from seven initiation points (red cells along blue flow paths). 


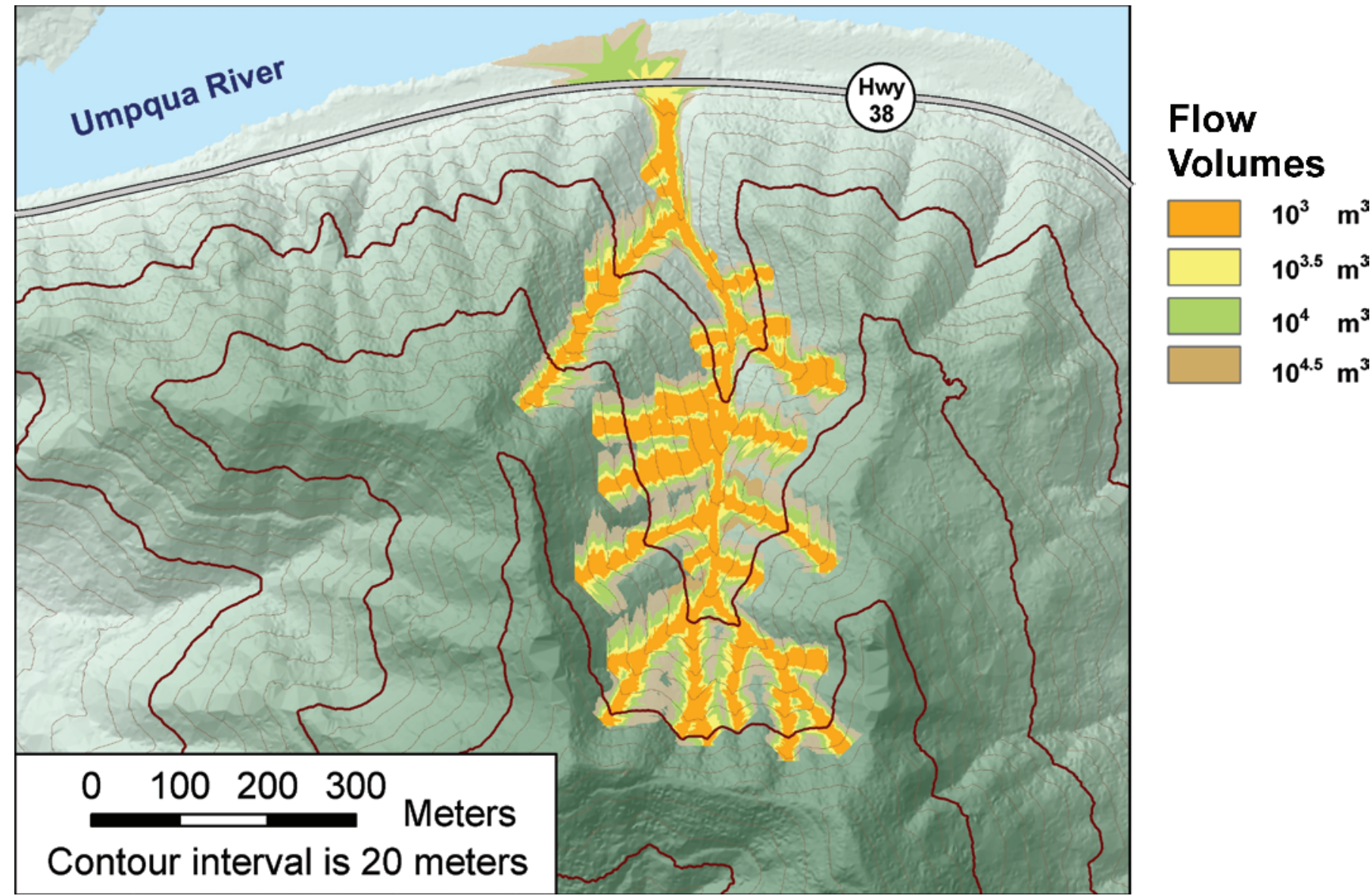

Figure 19. Debris-flow inundation-hazard map computed for four flow volumes ranging from $10^{3}$ to $10^{4.5} \mathrm{~m}^{3}$. Hazard zones show the predicted inundation limits for debris flows that start anywhere within the basin where the initiation criteria are met. The spikiness of the terminus of the LAHARZ hazard zones as the hypothetical flows spill out of the constricted channel are a result of the limitation of flow directions across gridded elevation data.

\section{Hazard Map Summary}

The modeled hazard zones do not predict the runout of a particular debris flow but instead delineate the paths likely to be inundated by a suite of debris flows with various volumes. The four nested hazard zones are colored from "cool" to "hot" to reflect which areas are most hazardous because they are subject to inundation by even the smallest debris flows. In general, hazard is greatest along channel thalwegs (fig. 20), and it decreases with distance and elevation above the valley floor. Moreover, bracketing flow volumes and using graded shades of color generates a hazard map that conveys visual uncertainty. The nested hazard zones are equivalent to error bars where the increments between flow volumes $\left(10^{0.5}\right)$ conservatively exceed the statistical errors inherent in the inundation equations $(0.32-0.45)$. The nested hazard zones imply that wide paths (sometimes overlapping between adjacent chan- nels) near channel heads are less likely to be inundated than are narrow paths.

The ragged edges of the computed inundation zones result from using a computational grid having only four potential transect directions (NW-SE, N-S, NE-SW, W-E) in which to calculate any cross-section. Furthermore, the computational methodology and, therefore, the hazard map do not account explicitly for changes in flow volume (due to entrainment or deposition) or run-up potential because the same predicted $A$-value is used to compute the inundation cross-section along the entire length of a potential debris-flow path. 

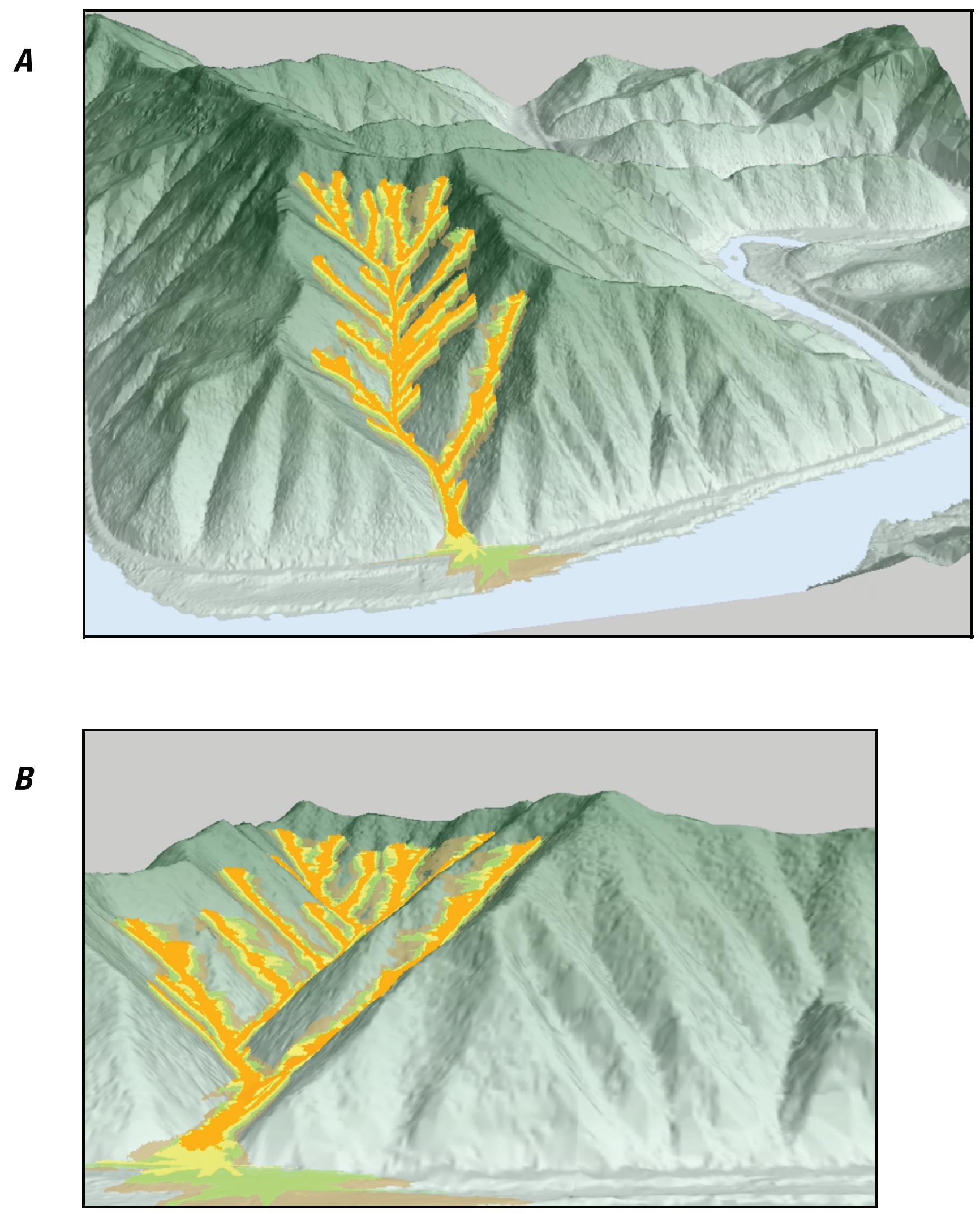

Figure 20. Oblique perspectives of the test basin with debris flow-hazard zone overlays, view to the southeast. $A$, Oblique aerial view. $B$, Up-valley view from the north bank of the Umpqua River, Oregon. 


\section{Conclusions}

The main objective of this work is to provide a statistically tested and calibrated model that can be used to forecast inundation by future debris flows and rock avalanches. To accomplish this objective, a database consisting of flow volumes, maximum inundated cross-sectional areas, and total inundated planimetric areas was compiled for 64 nonvolcanic debris flows ranging in volume from $10^{1}$ to $10^{7} \mathrm{~m}^{3}$ and for 143 rock avalanches ranging from $10^{5}$ to $10^{11} \mathrm{~m}^{3}$ in volume. The database complements the lahar inundation-area database of Iverson and others (1998) for events that range between $10^{5}$ and $10^{10} \mathrm{~m}^{3}$ in volume.

Power-law equations of the form Area $=\alpha \cdot$ Volume $^{2 / 3}$ with calibrated $\alpha$-coefficients provide a good fit $\left(r^{2}=0.76-0.91\right)$ to the debris-flow and rock-avalanche data with standard errors ranging from 0.45 to 0.32 . The resulting inundation-area equations for debris flows are $A=0.1$ $V^{2 / 3}$ and $B=20 V^{2 / 3}$, and the inundation-area equations for rock avalanches are $A=0.2 V^{2 / 3}$ and $B=20 V^{2 / 3}$, where $V$ is flow volume, $A$ is inundated cross-sectional area, and $B$ is inundated planimetric area. These equations are similar to a set of inundation-area equations $\left(A=0.05 V^{2 / 3}\right.$ and $B=200$ $V^{2 / 3}$ ) developed for lahars by Iverson and others (1998). The equations imply no scale dependence of the runout process for rock avalanches, debris flows and lahars, but the differing $\alpha$-coefficients of the equations indicate that the bulk mobilities of different types of flow can differ. Specifically, the $\alpha$-coefficients imply that rock avalanches and nonvolcanic debris flows are less mobile than lahars because they inundate planimetric areas roughly ten times smaller than do lahars of similar volume. The maximum cross-sectional area inundated by rock avalanches is, on average, four times greater than that of lahars and twice as large as that of debris flows of the same volume, although the statistical support for this distinction is weak. The similarity of the inundation-area equations for relatively small, nonvolcanic debris flows and much larger rock avalanches indicates that these two types of flows may have strong mechanical similarities, even though the processes operate on different scales.

Implementation of the inundation-area equations within the GIS-based program, LAHARZ, provides a repeatable, objective way to produce hazard maps. Use of a range of hypothetical flow volumes that span orders of magnitude provides graphical output that depicts uncertainty in the predicted inundation areas. Not knowing the volume of the next event and, therefore, the inundation limits for that volume, is tolerable where hazard is assessed in terms of relative likelihood of inundation for a range of flow volumes instead of the inundation limits of the next event.

A strength of this methodology compared to traditional hazard-mapping techniques is that a broad range of possible volumes is considered in delineating maximum inundation areas. Rather than making predictions of future runout based on the maximum extent of deposits of past events, this method allows for the possibility that future events will be larger than those in the historical or geologic record. A limitation of this methodology is that flow dynamics and run-up potential where granular mass flows encounter channel bends or obstacles are not considered. Another limitation is that events representing statistical outliers (defined by the curves of 99-percent level of confidence for prediction) will not be predicted accurately.

Quantifying recurrence intervals for specific flow volumes in a frequency-magnitude analysis for a particular region could assign probabilities to each flow volume and, therefore, assign annual likelihood that a specific postulated flow would reach a certain point down valley. Until such work is undertaken, postulating a range of future flow volumes provides an indication of the range of inundation possibilities.

\section{Acknowledgments}

The authors thank USGS colleagues Dennis Helsel and Susan Cannon for insightful reviews of this manuscript. Professor Albyn Jones of Reed College provided additional assistance in the statistical review of this work. Steve Schilling (USGS) wrote the original version of the computer program, LAHARZ, which was applied in this project. Michelle Howell collected a significant portion of the rock avalanche data. We thank Andrew Fountain and Scott Burns (Portland State University) for serving on the first author's Master's thesis committee and supervising phases of this project. Jason Hinkle (ODF) and Jon Hofmeister (DOGAMI) provided field guidance in the area around Scottsburg, Oregon.

\section{References Cited}

Baldwin, E. M., 1961, Geologic map of the lower Umpqua River area, Oregon: U.S. Geological Survey Oil and Gas Inventory Map OM-204, scale 1:62,500.

Benda, L.E., and Cundy, T.W., 1990, Predicting deposition of debris flows in mountain channels: Canadian Geotechnical Journal, v. 27, p. 409-417.

Cannon, S.H., 1989, An evaluation of the travel-distance potential of debris flows: Utah Geological and Mineral Survey Miscellaneous Publications, 89-2, 35 p.

Crandell, D.R., 1989, Gigantic debris avalanche of Pleistocene Age from Ancestral Mount Shasta Volcano, California, and debris-avalanche hazard zonation: U.S. Geological Survey Bulletin 1861.

Crandell, D.R., and Mullineaux, D.R., 1967, Volcanic hazards at Mount Rainier, Washington: U.S. Geological Survey Bulletin $1238,26 \mathrm{p}$. 
Crandell, D.R., and Mullineaux, D.R., 1975, Technique and rationale of volcanic-hazards appraisals in the Cascade Range, northwestern United States: Environmental Geology, vol.1, no.1, p. 23-32.

Crosta, G.B., Cucchiaro, S., and Frattini, P., 2003, Validation of semi-empirical relationships for the definition of debrisflow behavior in granular materials in Rickenmann, D., and Chen, C.-L., eds., Debris-flow hazards mitigation; mechanics, prediction, and assessment: Rotterdam, Millpress, p. $821-831$.

Dade, W.B., and Huppert, H.E., 1998, Long-runout rockfalls: Geology, v. 26, no. 9, p. 803-806.

Davies, T.R.H., 1982, Spreading of rock avalanche debris by mechanical fluidization: Rock Mechanics, v. 15, p. 9-24.

Denlinger, R.P., and Iverson, R.M., 2001, Flow of variably fluidized granular masses across three-dimensional terrain; 2 - Numerical predictions and experimental tests: Journal of Geophysical Research, v. 106, no. B1, p. 553-566.

Denlinger, R.P., and Iverson, R.M., 2004, Granular avalanches across irregular three-dimensional terrain; 1-Theory and computation: Journal of Geophysical Research, v. 109, F01014.

Eisbacher, G.H., and Clague, J.J., 1984, Destructive mass movements in high mountains; Hazard and management: Geological Survey of Canada, Paper 84-16, 230 p.

Fannin, R.J., and Rollerson, T., 1993, Debris flows; some physical characteristics and behaviour: Canadian Geotechnical Journal, v. 30, no. 1, p. 71-82.

Fannin, R.J., and Wise, M.P.W., 2001, An empirical-statistical model for debris

flow travel distance: Canadian Geotechnical Journal, v. 38, no. 5, p. 982-994.

Gardner, C.A., Scott, W.E., Ewert, J.W., Griswold, J.P., Johnson, M.C., and Devoli, G., 2004, Volcano hazard zones for Volcàn Momotombo, Nicaragua: U.S. Geological Survey Open-file Report 2004-1012.

Griswold, J.P., 2004, Mobility statistics and hazard mapping for non-volcanic debris flows and rock avalanches: Portland, Oregon, Portland State University, master's thesis, $102 \mathrm{p}$.

Haan, C.T., 1977, Statistical methods in hydrology: Ames, Iowa State University Press, 378 p.

Haapala, J.M., Escobar Wolf, R., Vallance, J.W., Rose, W.I., Griswold, J.P., Schilling, S.P., Ewert, J.W., and Mota, M., 2005, Volcanic hazards at Atitlan Volcano, Guatemala: U.S. Geological Survey Open-File Report 2005-1403, 19 p.
Helsel, D.R., and Hirsch, R.M., 1992, Statistical methods in water resources: Amsterdam, Elsevier, 529 p.

Heim, A., 1921, Geologie der Schweiz. Band 2: die Schweizer Alpen 1. Halfte. Tauchniz Leipzig.

Heim, A., 1932, Der bergsturz und Menschenleben: Zurich, Fretz und Wasmuth, $218 \mathrm{p}$.

Hsu, K.J., 1975, Catastrophic debris streams (sturzstroms) generated by rockfalls: Geological Society of America Bulletin, v. 86, p. 129-140.

Hungr, O., 1990, Mobility of rock avalanches: Report of the National Research Institute for Earth Science and Disaster Prevention, Japan, v. 46, p. 11-20.

Iverson, R.M., 1997, The physics of debris flows: Reviews of Geophysics, v. 35, no. 3, p. 245-296.

Iverson, R.M., 2003, The debris-flow rheology myth in Rickenmann, D., and Chen, C.-L., eds., Debris-flow hazards mitigation; mechanics, prediction, and assessment: Rotterdam, Millpress, p. 303-314.

Iverson, R.M., 2005, Regulation of landslide motion by dilatancy and pore pressure feedback: Journal of Geophysical Research, v. 110, F02015.

Iverson, R.M., Costa, J.E., and LaHusen, R.G., 1992, Debrisflow flume at H.J. Andrews Experimental Forest, Oregon: U.S. Geological Survey Open-File Report 92-483, 2 p.

Iverson, R.M., and Denlinger, R.P., 2001, Flow of variably fluidized granular masses across three-dimensional terrain; 1- Coulomb mixture theory: Journal of Geophysical Research, v. 106, no. B1, p. 537-552.

Iverson, R.M., Logan, M., and Denlinger, R.P., 2004, Granular avalanches across irregular three-dimensional terrain; 2Experimental tests: Journal of Geophysical Research, v. 109, F010115.

Iverson, R.M., Reid, M.E., and LaHusan, R.G., 1997, Debrisflow mobilization from landslides: Annual Review of Earth and Planetary Sciences, v. 25, p. 85-138.

Iverson, R.M., Schilling, S.P., and Vallance, J.W., 1998, Objective delineation of lahar-hazard inundation zones: Geological Survey of America Bulletin, v. 110, no. 8, p. 972-984.

Iverson, R.M., and Vallance, J.W., 2001, New views of granular mass flows: Geology, v. 29, no. 2, p. 115-118.

[Jackli, 1957] compiled in Li Tianchi, 1983, A mathematical model for predicting the extent of a major rockfall: Zeitschrift fur Geomorphologi N.F., Bd. 27, heft. 24, p. $472-482$. 
Jakob, M., and Hungr, O., eds., 2005, Debris-flow hazards and related phenomena, New York, Springer, 739 p.

Janda, R.J., Scott, K.M., Nolan, K.M., and Martinson, H.A., 1981, Lahar movement, effects and deposits, in Lipman, P.W., and Mullineaux, D.R., eds., The 1980 eruptions of Mount St. Helens, Washington, U.S. Geological Survey Professional Paper 1250, p. 461-478.

Jefferys, W.H., and Berger, J.O., 1992, Ockham's Razor and Bayesian Analysis: American Scientist, v. 80, p. 64-72.

Johnson, A.M., 1984, Debris flow, in Brunsden, D., and Prior, D.B., eds., Slope instability: New York, John Wiley and Sons, p. 257-361.

Jordan, P.R., 1994, Debris flows in the Southern Coast Mountains, British Columbia: Dynamic Behaviour and Physical Properties: Vancouver, University of British Colombia, Ph.D. dissertation, $260 \mathrm{p}$.

Ketcheson, G., and Froelich, H.A., 1978, Hydrologic factors and environmental impacts of mass soil movements in the Oregon Coast Range, Corvallis, Oregon: Water Resources Research Institute Bulletin 56, Oregon State University.

Keselman, H.J., Othamn, A.R., Wilcox, R.R., and Fradette, K., 2004, The new and improved two-sample t test: Psychological Science, v. 15 , no. 1, p. 47-51.

Kilburn, C.R.J. and Sorenson, S.A., 1998, Runout lengths of sturztroms; the control of initial conditions and of fragment dynamics: Journal of Geophysical Research, v. 102, no. B8, p. $17877-17884$.

Legros, F., 2002, The mobility of long-runout landslides, Engineering Geology, v. 63, 301-331.

Li Tianchi, 1983, A mathematical model for predicting the extent of a major rockfall: Zeitschrift für Geomorphologie, v. 27, p. $473-482$.

Major, J.J., 1984, Geological and rheologic characteristics of the May 18, 1980 southwest flank lahars at Mount St. Helens, Washington: University Park, Pennsylvannia State University, Master's thesis, $225 \mathrm{p}$.

Major, J.J., 1996, Experimental studies of deposition by debris flows; Process, characteristics of deposits, and effects of pore-fluid pressure: Seattle, University of Washington, Ph.D. dissertation, $341 \mathrm{p}$.

Mapes, J., and Tims, D., 1996, Storm claims five lives: Portland, Oregonian Publishing Company, Sunrise edition, November 20, 1996, p. A01.

Montogmery, D.R., and Dietrich, W.E., 1994, A physically based model for the topographic control on shallow landsliding: Water Resources Research, v. 30, p. 1153-1172.
Myers, B., and Brantley, S. R., 1995, Volcano hazards fact sheet; hazardous phenomena at volcanoes: U.S. Geological Survey Open-File Report 95-231, 2 p.

Oregon Emergency Management Plan (OEMP), 2000, Landslides and debris flows: Natural hazards mitigation plan, v. 1, June 2000 .

The Oregonian, 1996, Landslides near Reedsport a 'nightmare': Portland, Oregonian Publishing Company, Sunrise edition, November 22, 1996, from wire reports, p. B04.

Peitgen, H.O., Hartmut J., and Dietmar, S., 1992, Chaos and fractals; new frontiers of science: New York, SpringerVerlag, $984 \mathrm{p}$.

Pierson, T.C., 1985, Initiation and flow behavior of the 1980 Pine Creek and Muddy River lahars, Mount St. Helens, Washington: Geological Survey of America Bulletin, v. 96, p. 1056-1069.

Pierson, T.C., and Costa, J.E., 1987, A rheologic classification of subaerial sediment-water flows, in Costa, J.E., and Wieczorek, G.E., eds., Debris flows/avalanches-Process, recognition, and mitigation, Geological Society of America Reviews in Engineering Geolgoy, v. 7, p.1-12.

Rickenmann, D., 1999, Empirical relationships for debris flows: Natural Hazards, v. 19, p. 47-77.

Reid, M.E., and Iverson, R.M., 1992, Gravity-driven groundwater flow and slope failure potential, 2- Effects of slope morphology, material properties, and hydraulic heterogeneity: Water Resources Research, v. 28, no. 3, p. 939-950.

Robinson, E.G., Mills, K., Paul, J.T., Dent L., and Skaugset, A., 1999, 1996 storm impacts monitoring project; Final Report—Forest Practices Technical Report \#4: Salem, Oregon Dept. Forestry, 157 p.

Sassa, K., 1988, Geotechnical model for the motion of landslides, in Bonnard, C., ed., Proceedings, 5th international symposium on landslides, v. 1: Rotterdam, Netherlands, A.A. Balkema, p. 37-55.

Savage, S.B., and Iverson, R.M., 2003, Surge dynamics coupled to pore-pressure evolution in debris flows in Rickenmann, D., and Chen, C.-L., eds., Debris-flow hazards mitigation; mechanics, prediction, and assessment: Rotterdam, Millpress, p. 503-514.

Scheidegger, A., 1973, On the prediction of the reach and velocity of catastrophic landslides: Rock Mechanics, v. 5, p. 231-236.

Schickler, W. and Thorpe, A., 2001, Surface estimation based on LIDAR: Proceedings of ASPRS Annual Conference, St. Louis, Missouri, April 2001. 
Scott, K.M., Wolfe, E.W. and Driedger, C.L., 1998, Mount Rainier - Living with perilous beauty: U.S. Geological Survey Fact Sheet 065-97, 4 p.

Scott, W.E., Iverson, R.M., Schilling, S.P., and Fisher, B.J., 2001, Volcano hazards in the Three Sisters Region, Oregon: Vancouver, Washington, U.S. Geological Survey Open-File Report 99-437, 18 p.

Schilling, S.P., 1998, LAHARZ; GIS programs for automated mapping of lahar-inundation hazard zones: U.S. Geological Survey Open-File Report 98-638, 80 p.

Schilling, S.P., Vallance, J.W., Matías, O., and Howell, M.M., 2001, Lahar hazards at Agua Volcano, Guatemala: U.S. Geological Survey Open-File Report 01-432.

Schuster, R.L., 1996, The 25 most catastrophic landslides of the 20th century in Chacón, J., Irigaray, C., and Fernádez, T., eds., Proceedings of the Eighth international conference and field trip on landslides, Granada City, Spain, Sept. 27-28, 1996: Rotterdam, A.A. Balkema, p. 53-62.

Sheridan, M.F., Hubbard, B., Hooper, D., and Abrams, M. 1999, Hazard zones demarking inundation limits for debris flows and debris avalanches at Volcán Colima, México: EOS, Transactions American Geophysical Union Fall Meeting, v. 80 , no. 46 , p. 1141.

Shreve, R.L., 1968, Leakage and fluidization in air-layer lubricated avalanches: Geological Survey of America Bulletin, v. 79 , p. 653-658.

Sidle, R.C., and Chigira, M., 2004, Landslides and debris flows strike Kyushu, Japan: EOS Transactions, v. 85, no. 15, p. 145,151 .
Siebert, L., 1984, Large volcanic debris avalanches; Characteristics of source areas, deposits, and associated eruptions: Journal of Volcanology and Geothermal Research, v. 22, p. 163-197.

Siebert, L., Glicken, H., and Ui, T., 1987, Volcanic hazards from Bezymianny - and Bandai-type eruptions: Bulletin of Volcanology, v. 49, p. 435-459.

Sorenson, O.E., 2003, Hazard mapping at Tungurahua volcano, Ecuador: Houghton, Michigan Tech University, Master's thesis.

Takahashi, T., 1991, Debris flow: Rotterdam, Balkema, 165 p.

Ui, T., 1983, Volcanic dry avalanche deposits - Identification and comparison with nonvolcanic debris stream deposits: Journal of Volcanology and Geothermal Research, v. 18, p. $135-150$.

Ui, T., H. Yamamoto, and Suzuki-Kamata, K., 1986, Characterization of debris avalanche deposits in Japan: Journal of Volcanology Geothermal Research, v. 29, p. 231-243.

Vallance, J.W., Schilling, S.P., Devoli, G., Reid, M.E., and Howell, M.M., 2001, Lahar hazards at Casita volcano, Nicaragua: Vancouver, Washington, U.S. Geological Survey Open-File Report 01-468, 24 p.

Vallance, J.W., and Scott, K.M., 1997, The Osceola mudflow from Mount Rainer - Sedimentology and hazards implications of a huge clay-rich debris flow: Geological Survey of America Bulletin, v. 109, p. 143-163.

Voight, B., ed., 1979, Rockslides and avalanches; natural phenomena in Developments in geotechnical engineering 14A: Elsevier, Amsterdam, 833 p.

Voight, B.R., Janda, J., Glicken, H., and Douglas, P.M., 1983, Nature and mechanics of the Mount St. Helens rockslideavalanche on 18 May 1980: Geotechnique, v. 33, p. 243-273.

Weisberg, S., 1985, Applied linear regression 2d ed.: New York, Wiley, 324 p.

Wesolowsky, G.O., 1976, Multiple linear regression and analysis of variance - An introduction for computer users in management and economics: New York, Wiley, 292 p. 


\section{Appendix A-Data Table}

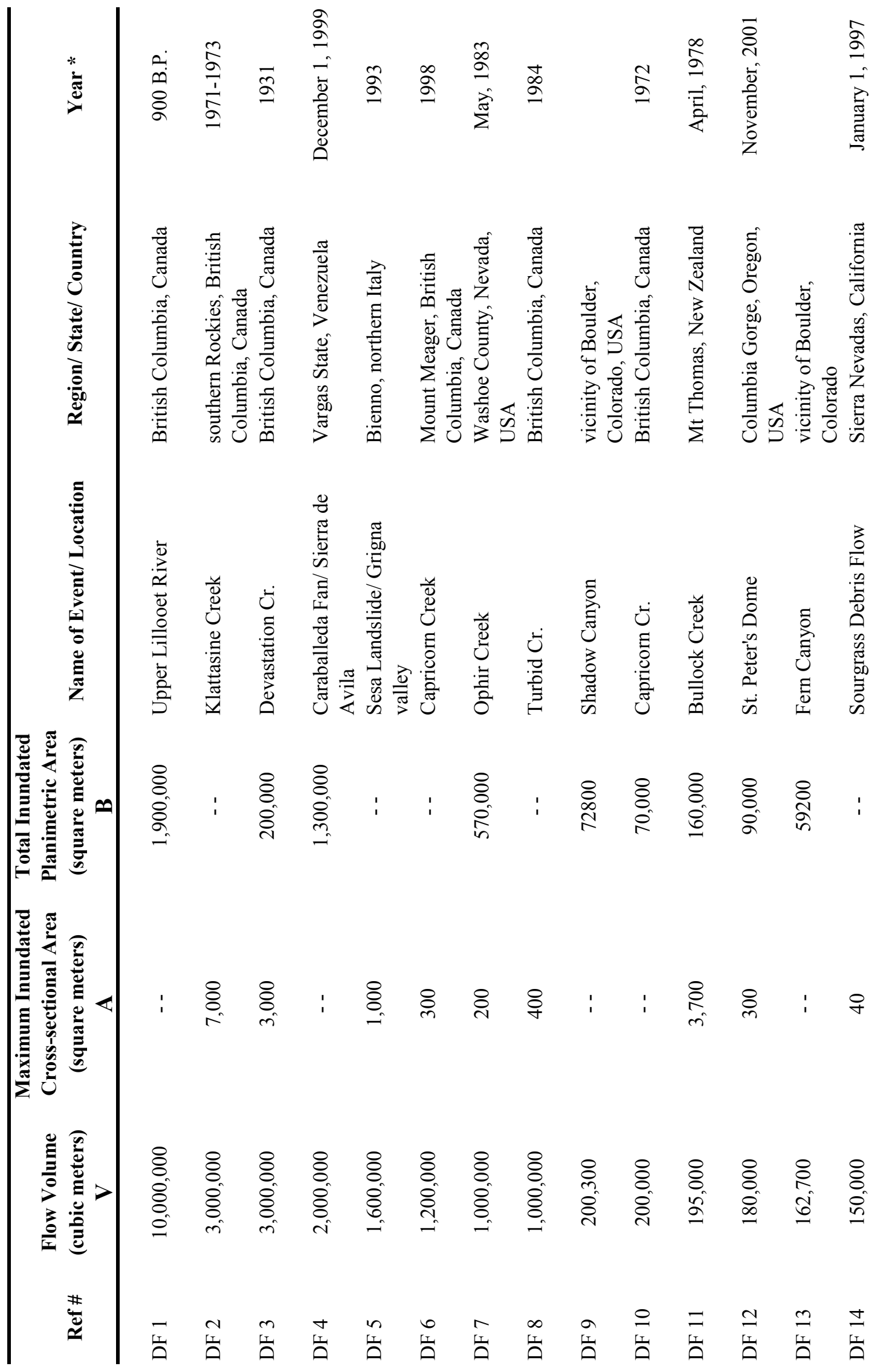




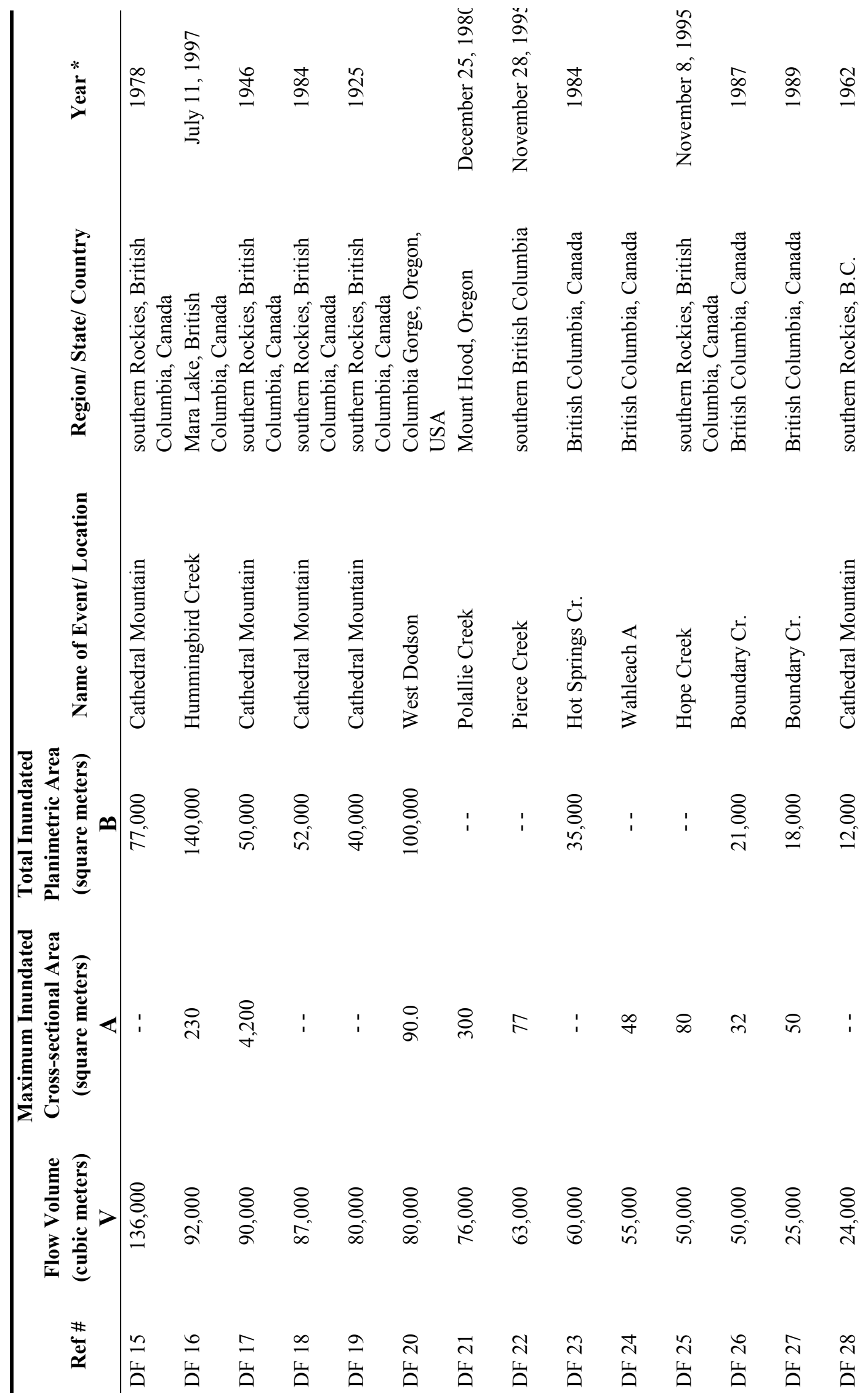




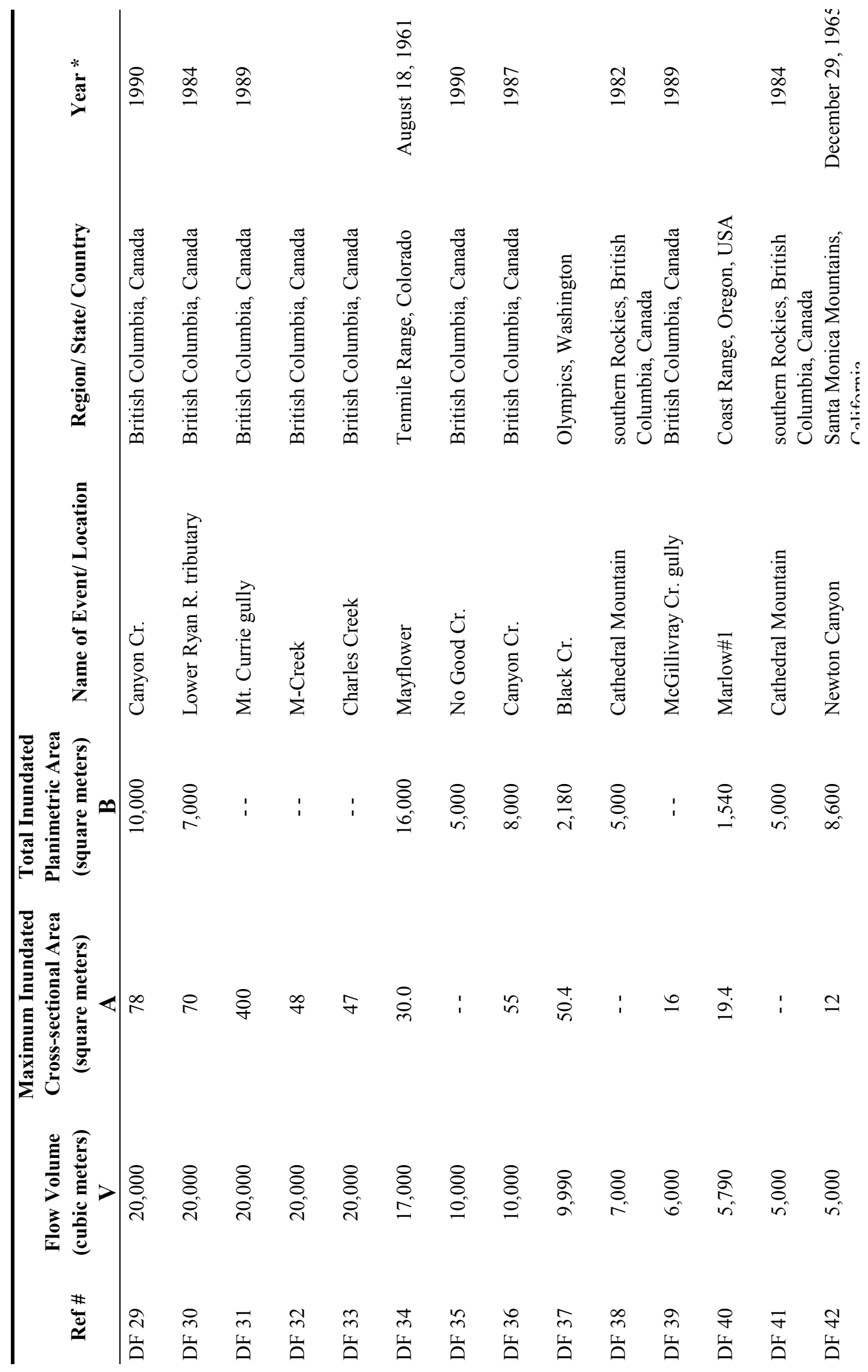




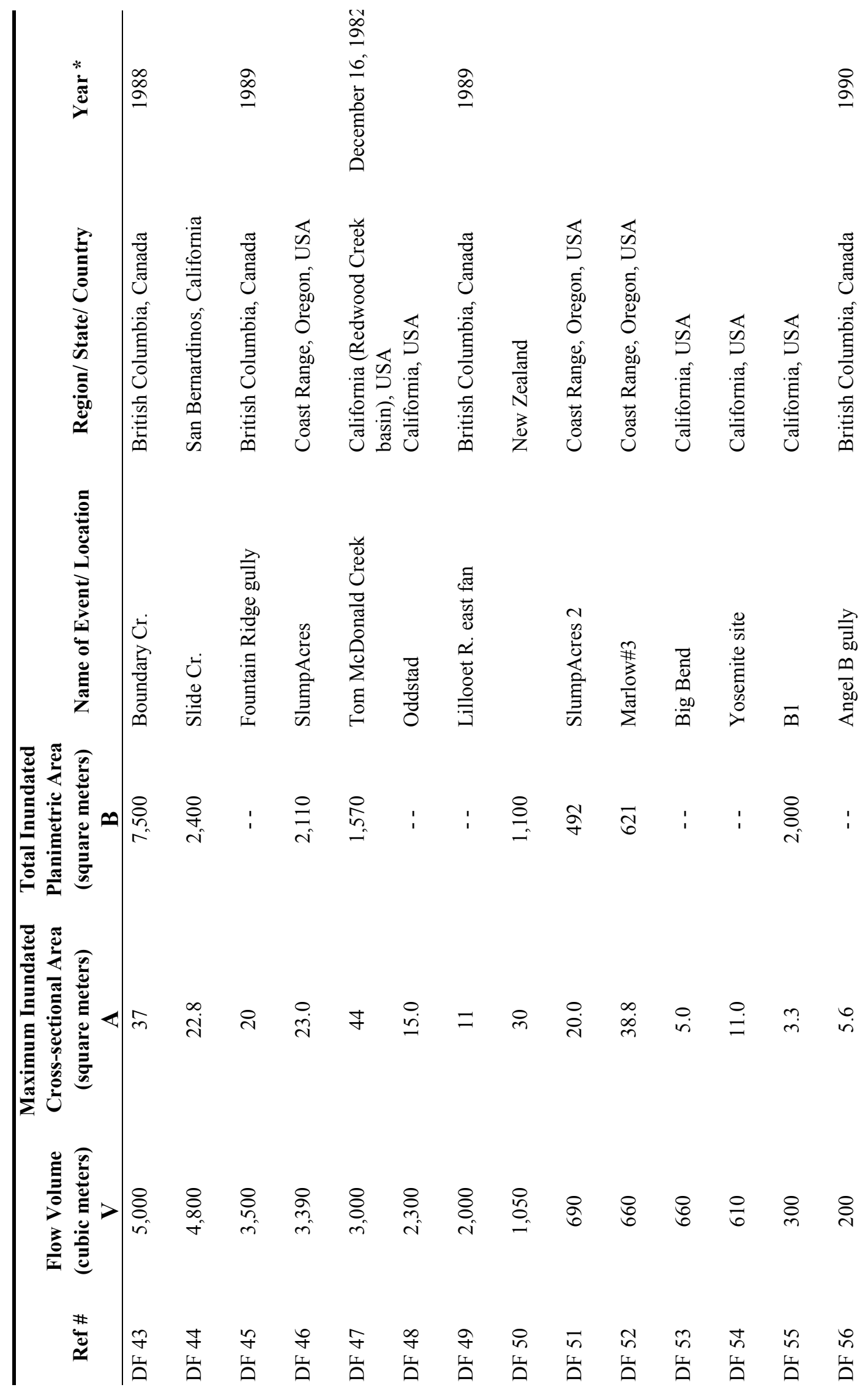




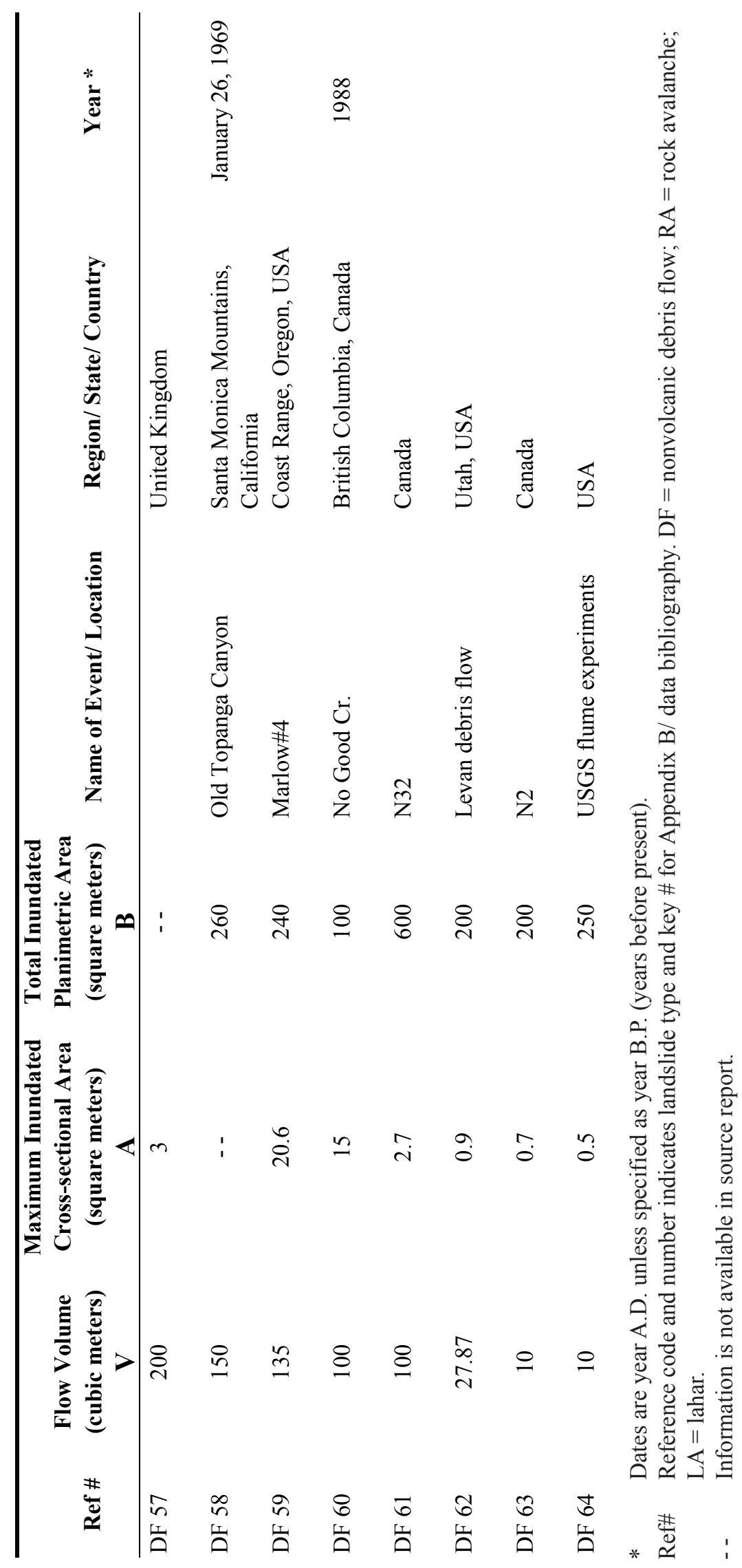




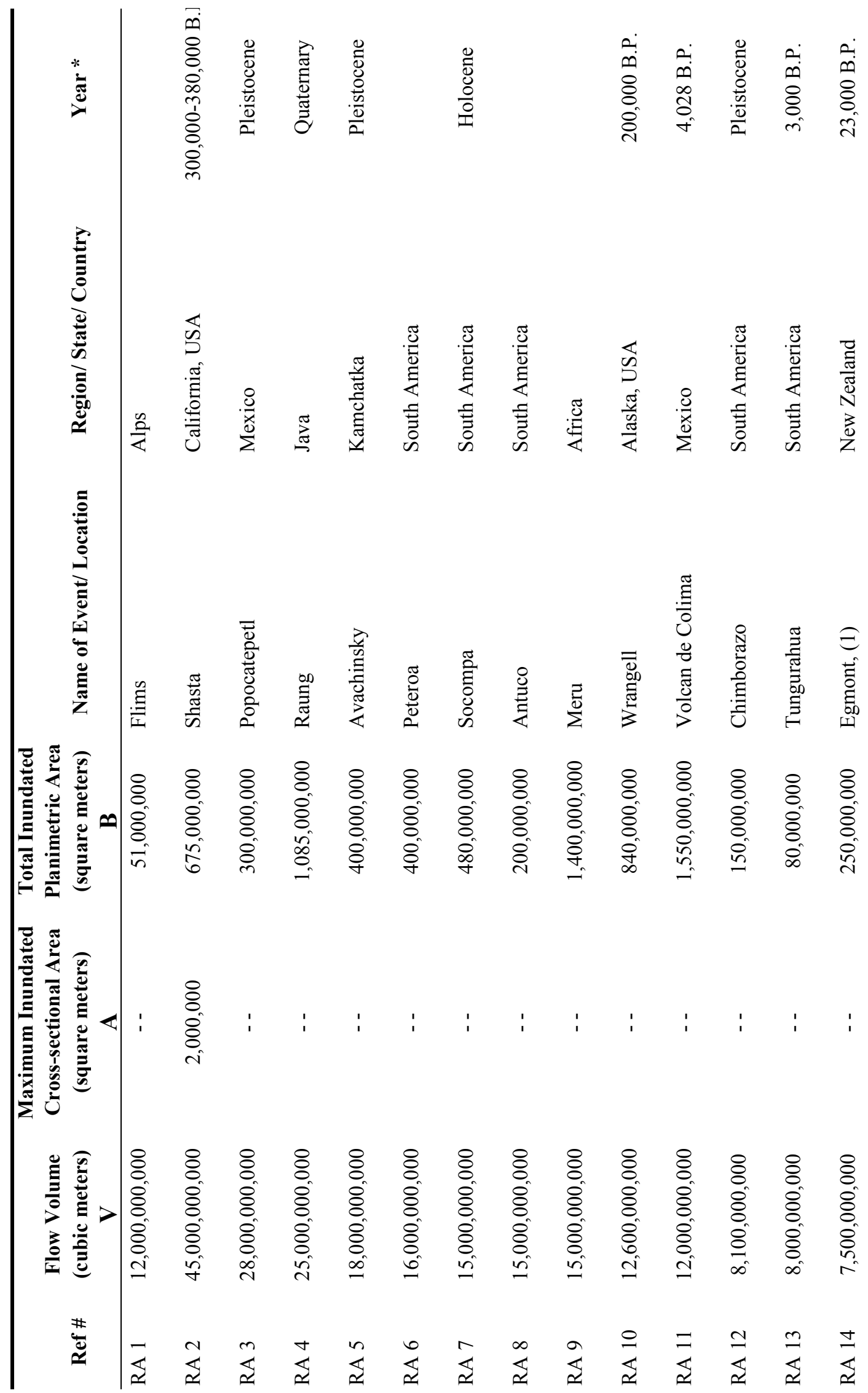




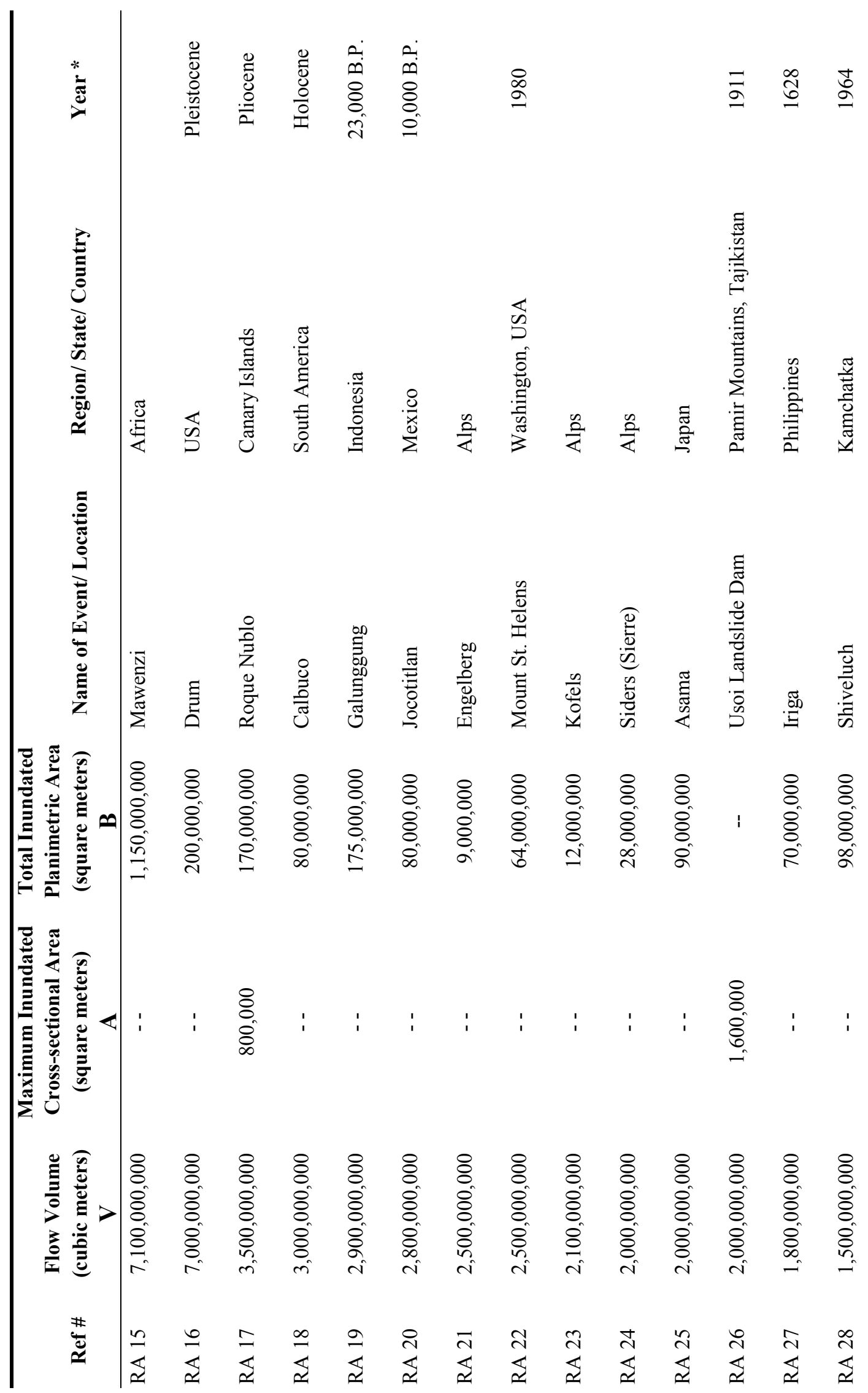




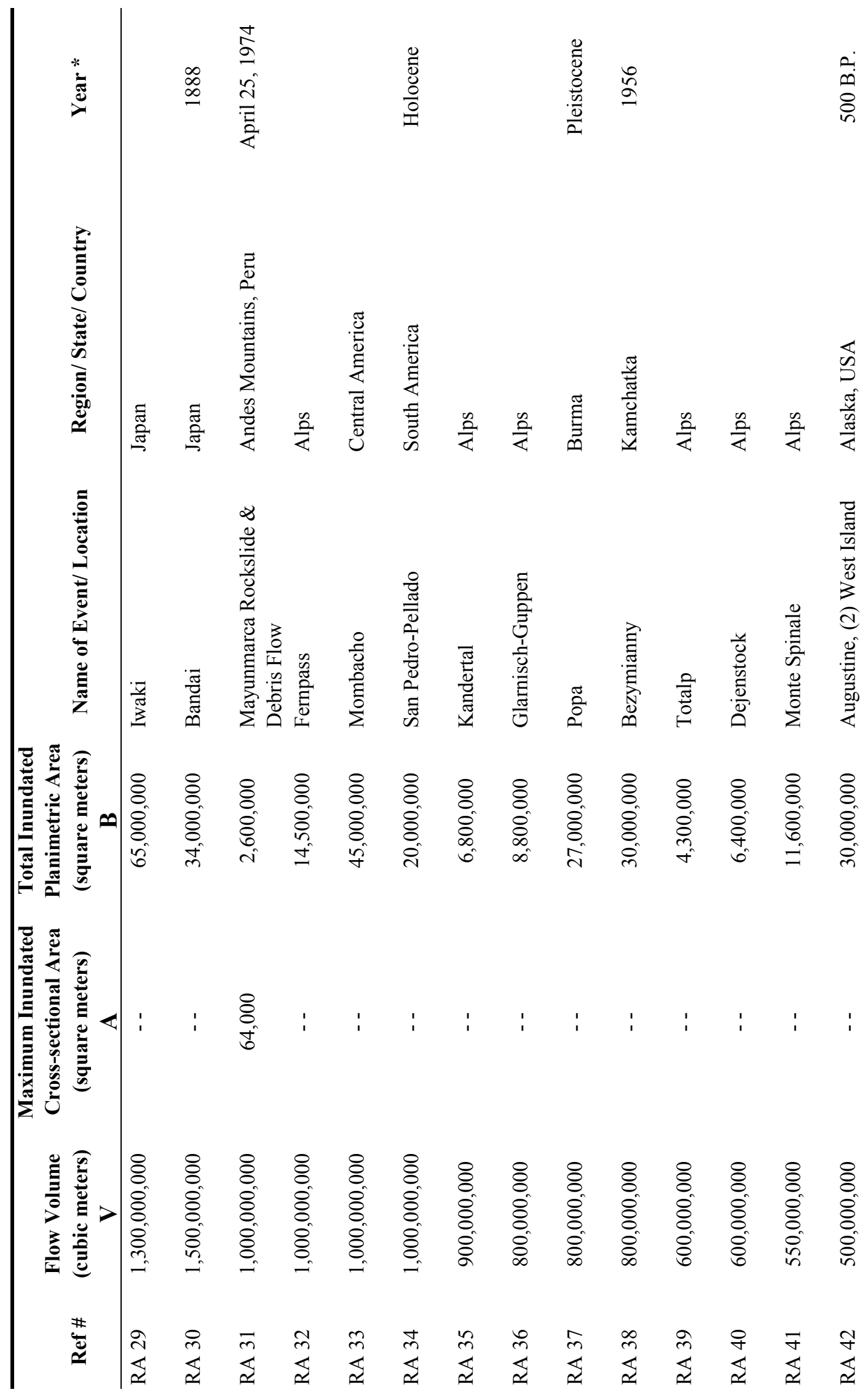




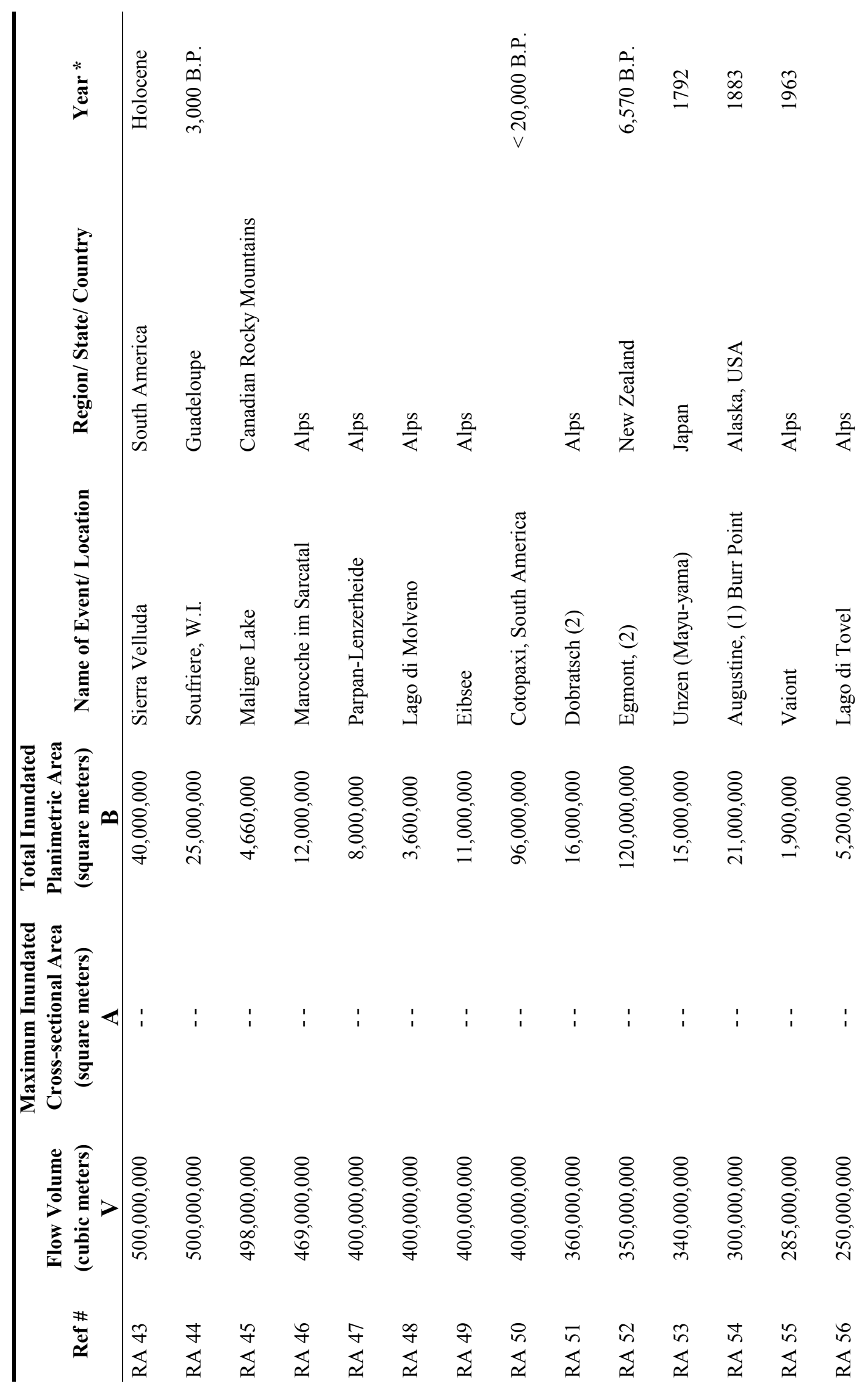




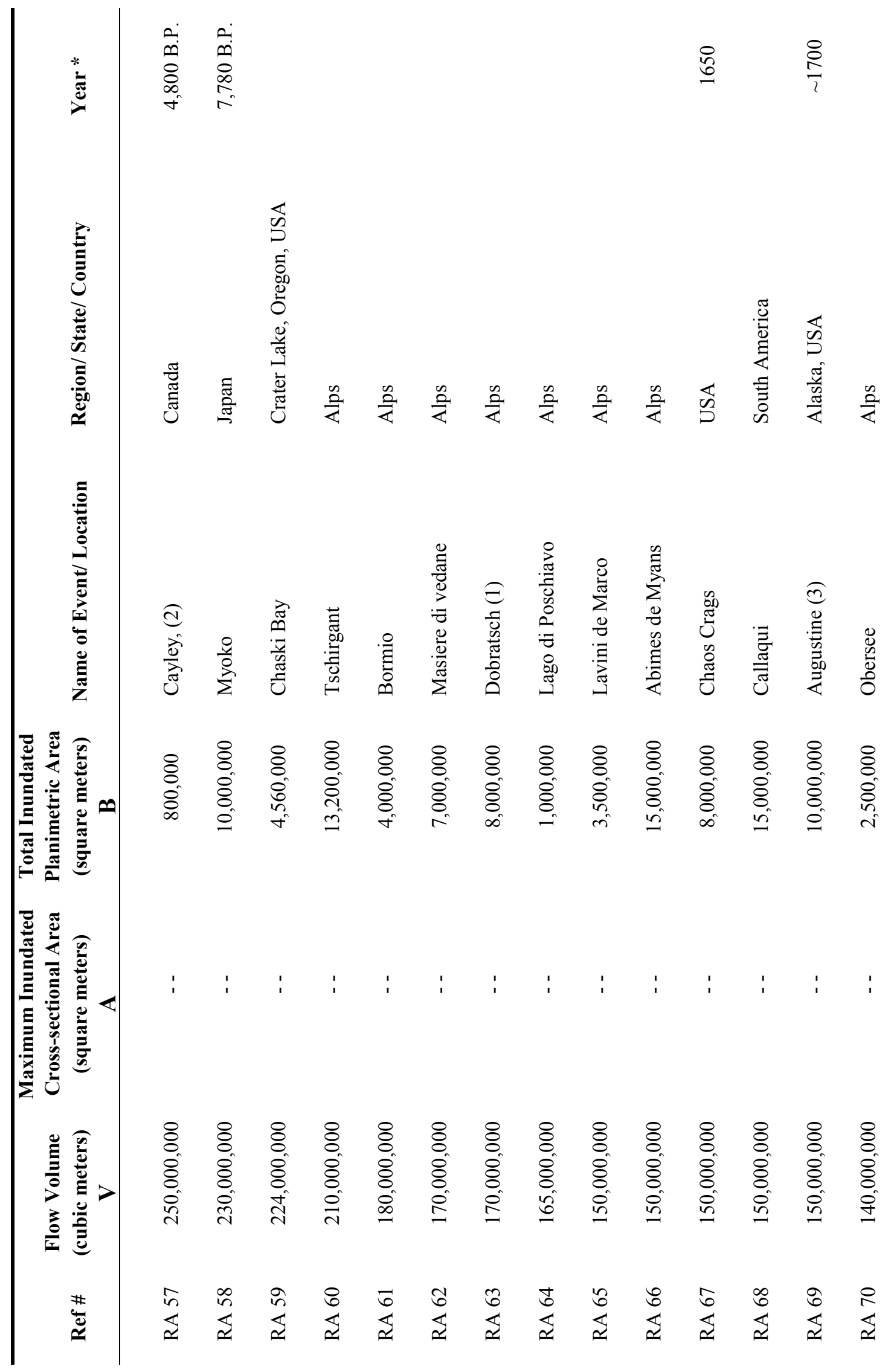




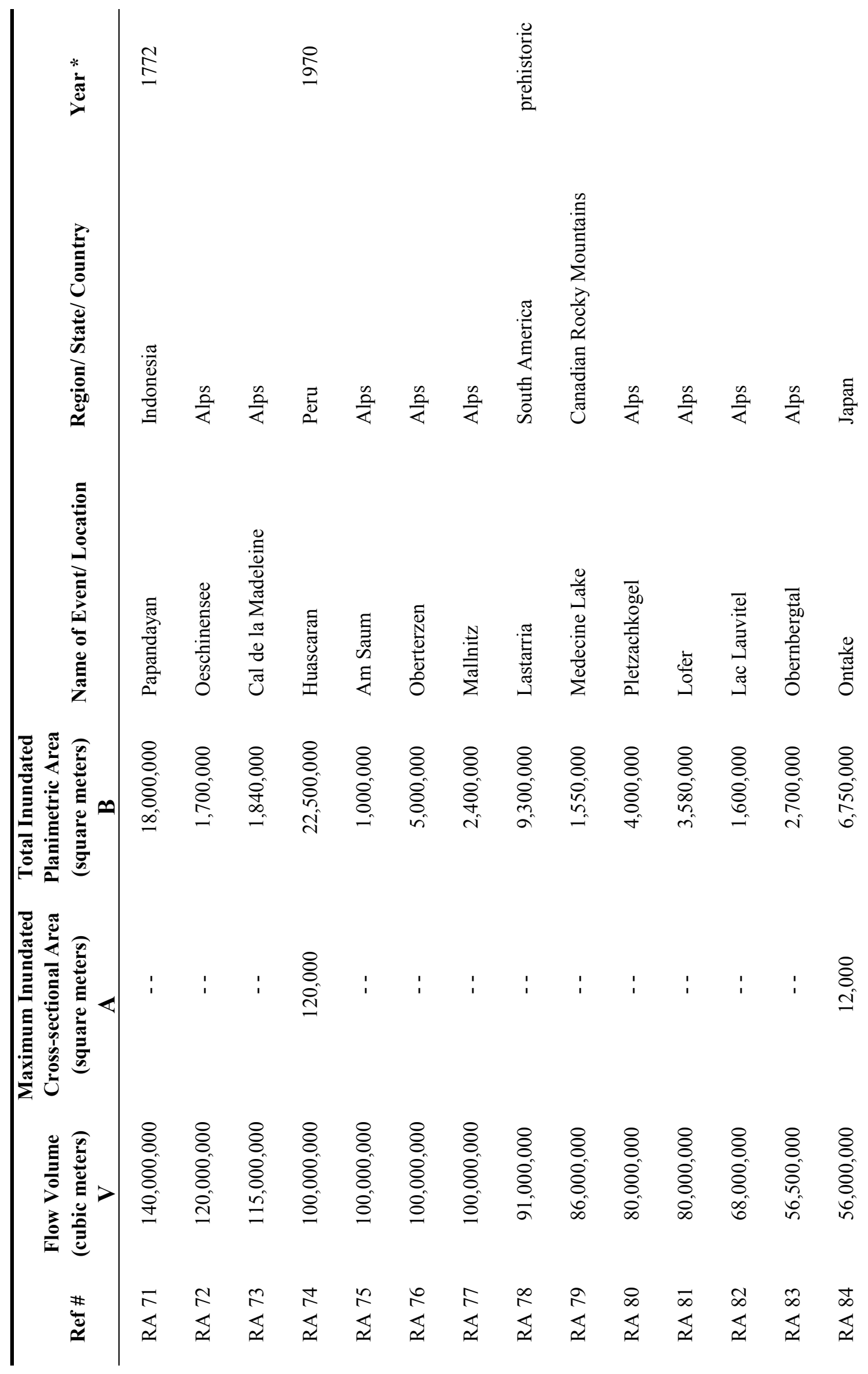




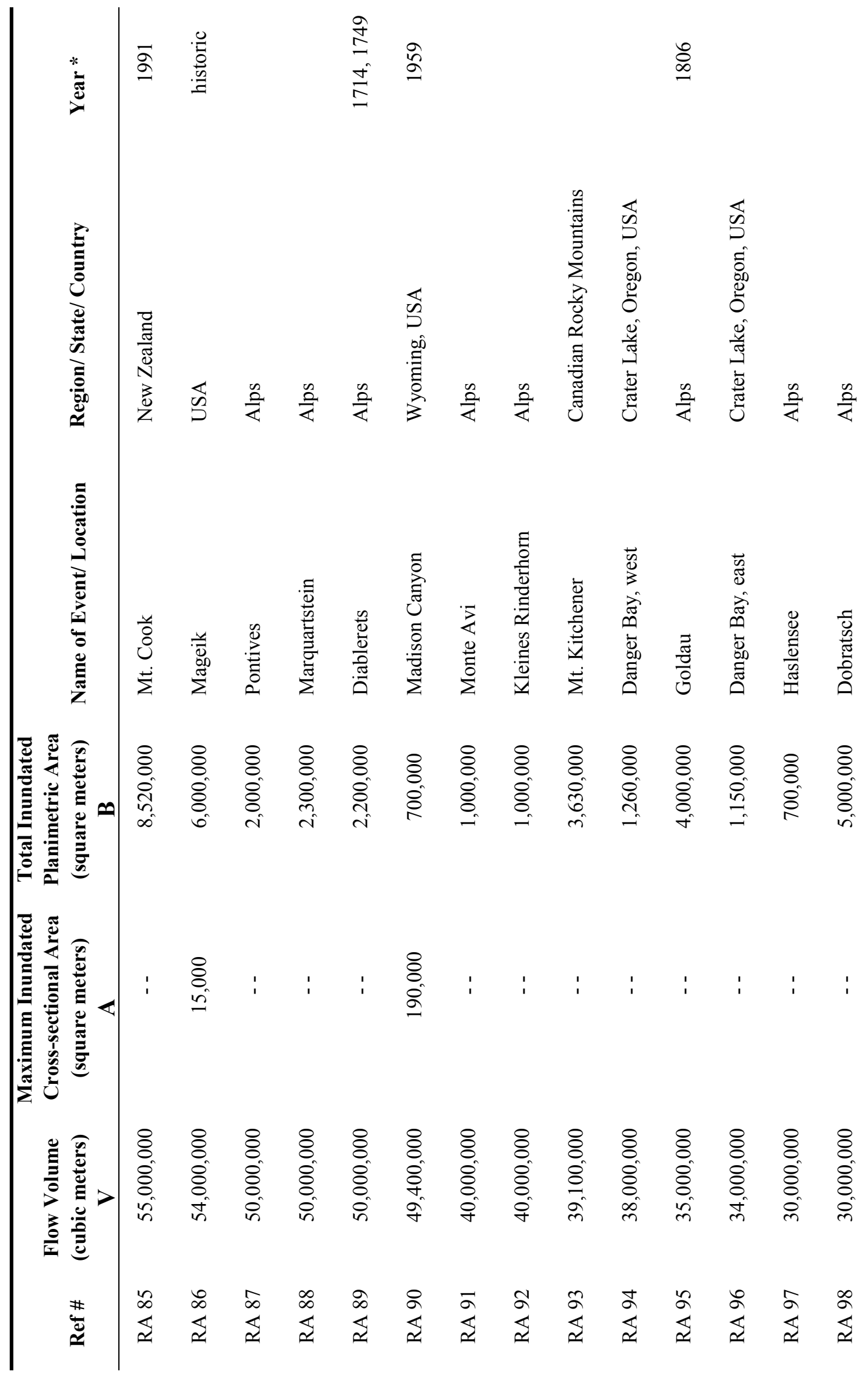




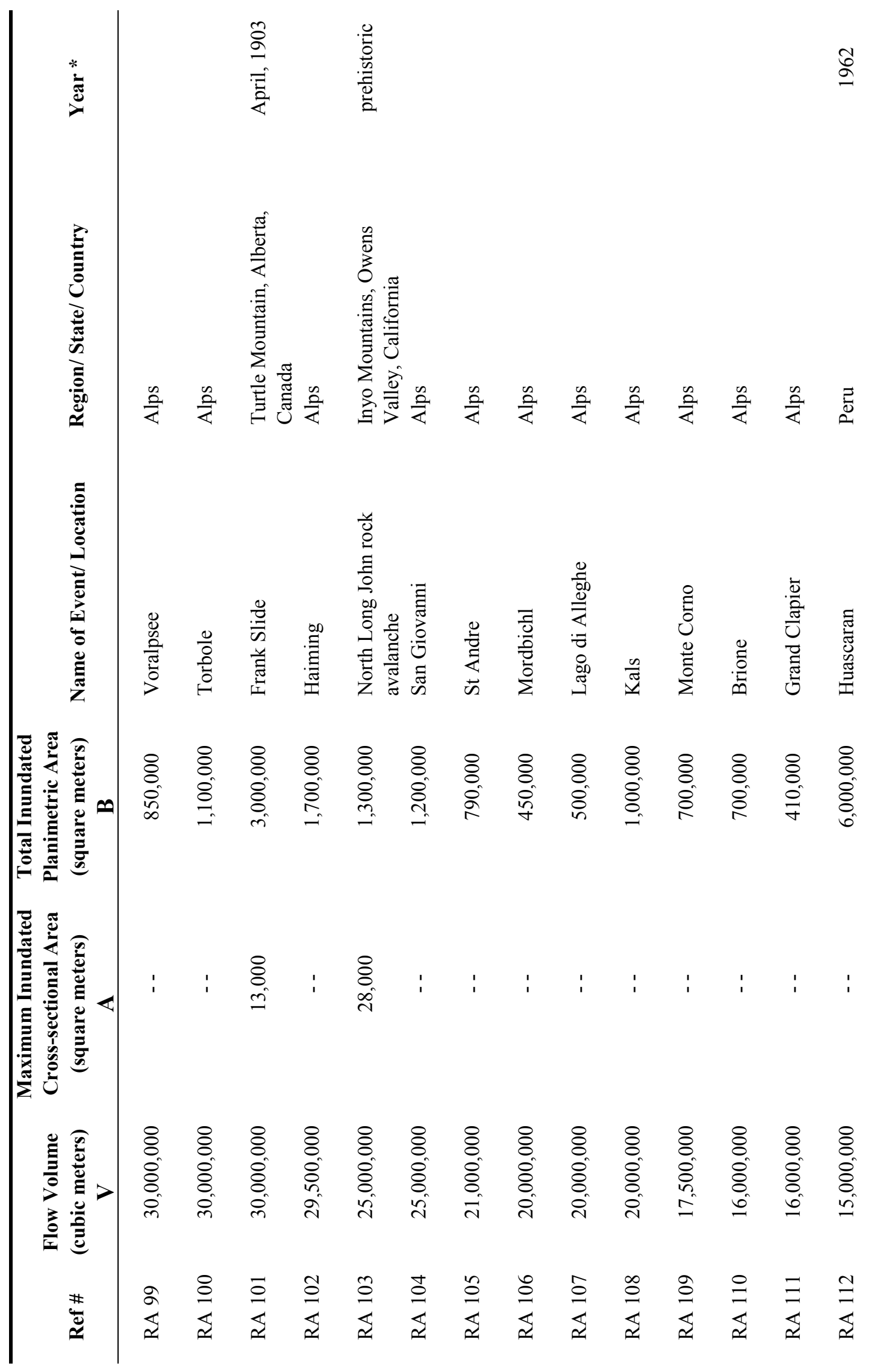




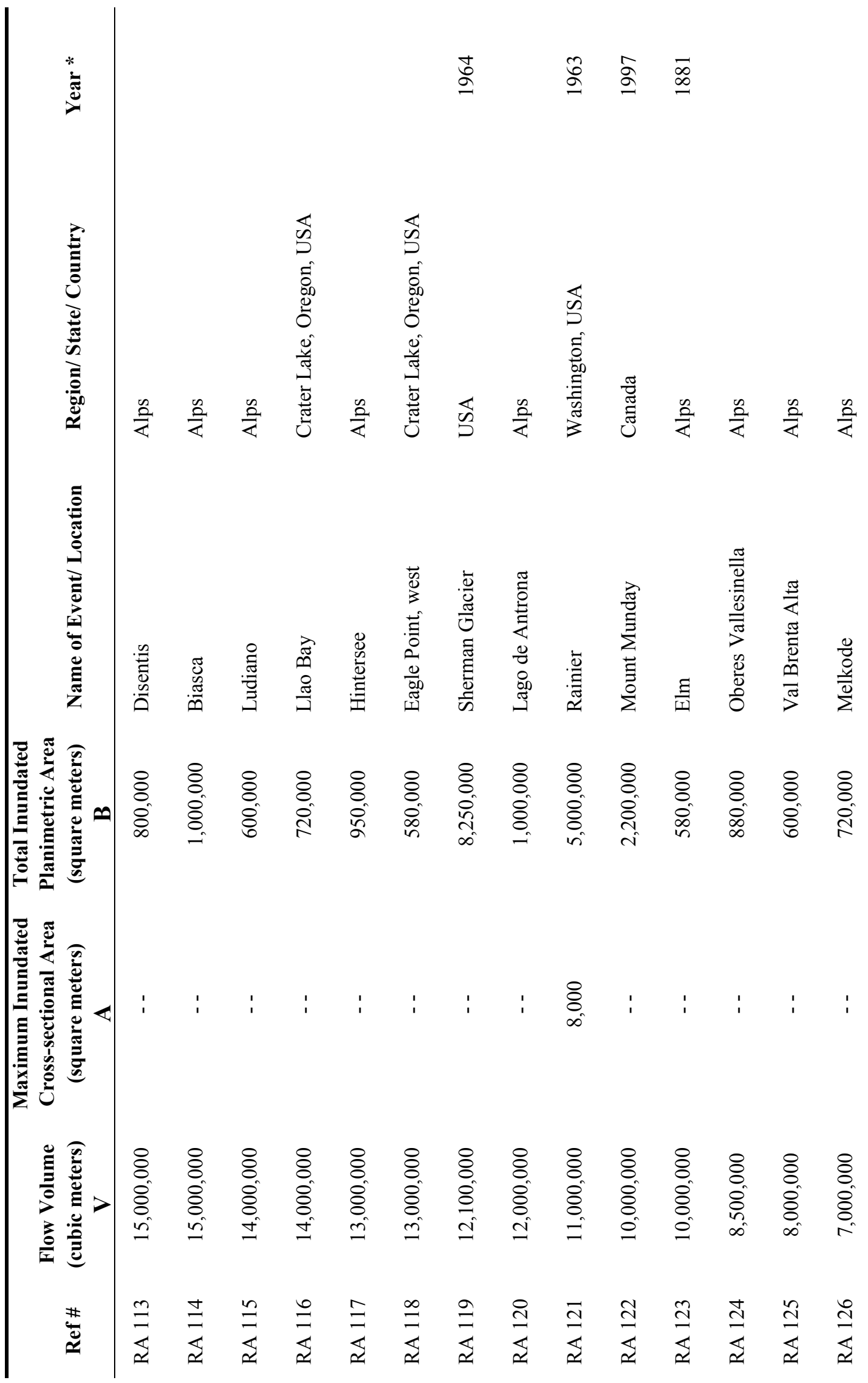




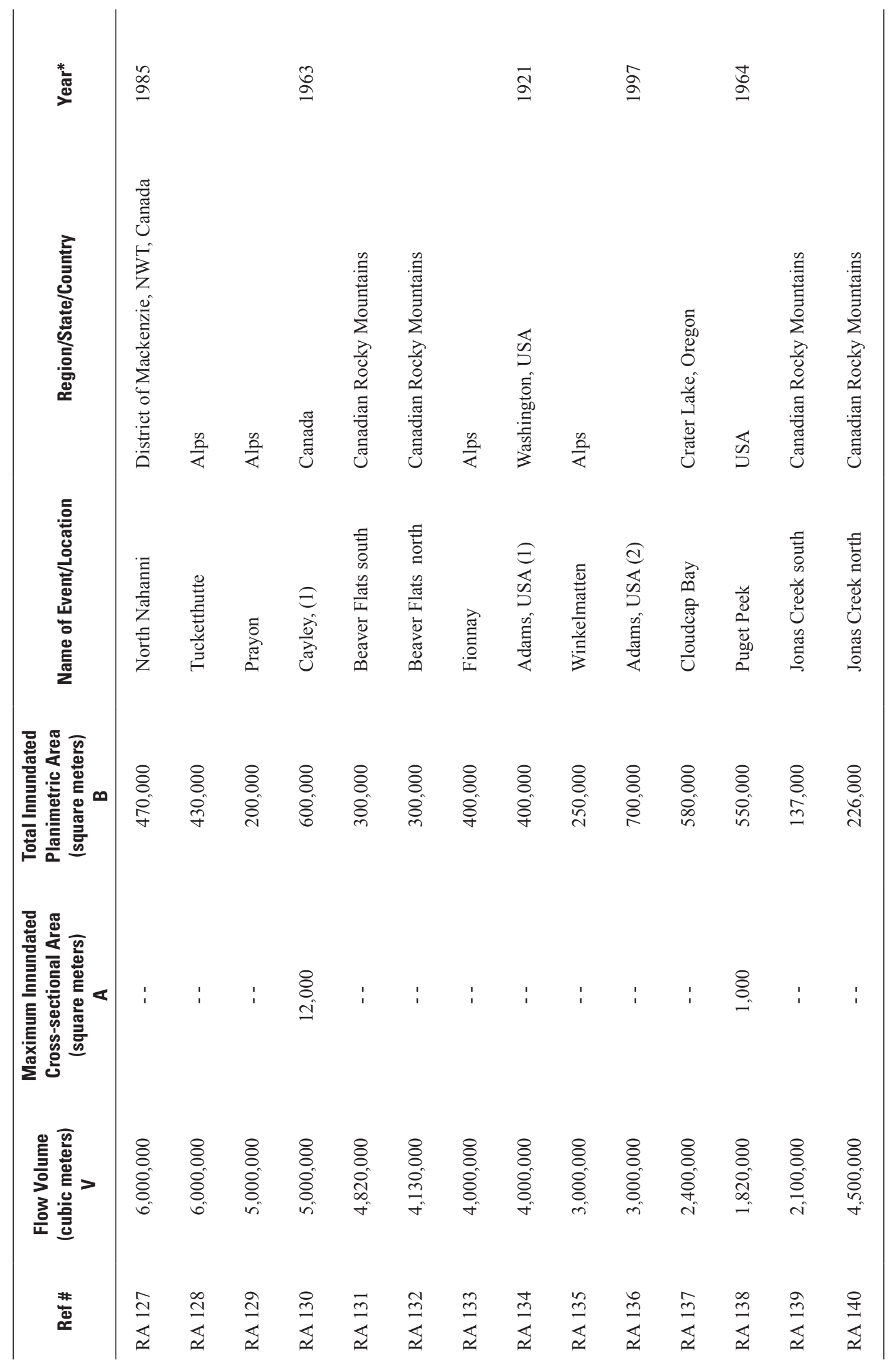




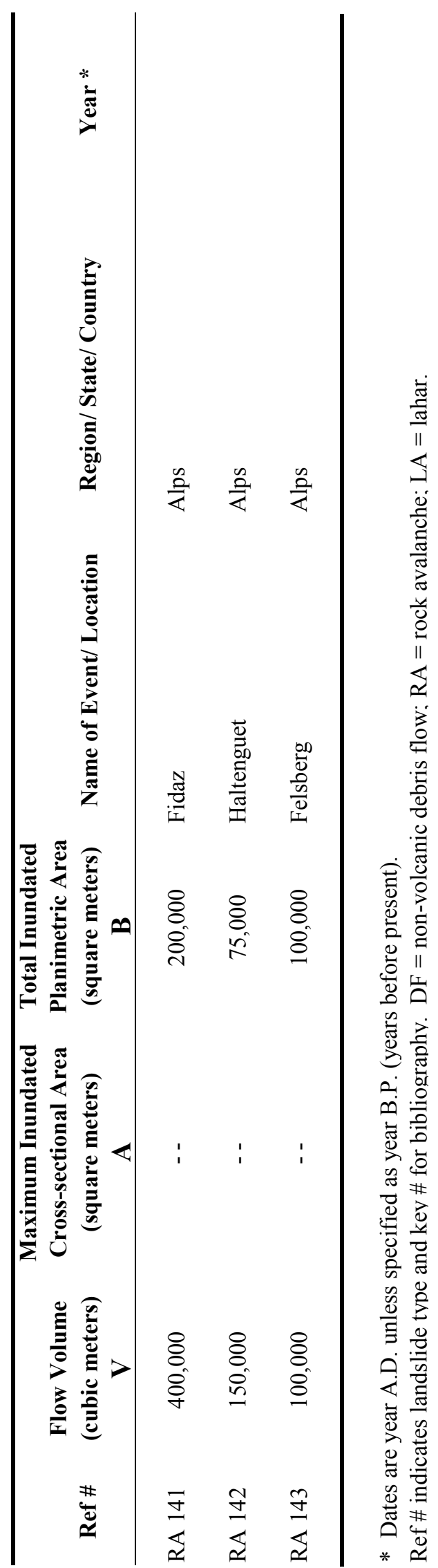




\section{Appendix B-Data Bibliography}

\section{Data References for Appendix A, Debris Flows}

DF 1 Jordan, P., 1994, Debris flows in the southern Coast Mountains, British Columbia: dynamic behaviour and physical properties: University of B.C. PhD thesis, 260 p.

DF 2 Clague, J. J., and Evans, S. G., 1994, Formation and Failure of Natural Dams in the Canadian Cordillera: Geological Survey of Canada, Geological Survey of Canada Bulletin 464.

Clague, J. J., Evans, S. G., and Blown, I. G., 1985, A debris flow triggered by the breaching of a moraine-dammed lake, Klattasine Creek, British Columbia: Canadian Journal of Earth Sciences, v. 22, no. 10, p. 1492-1502.

DF 3 Jordan, P., 1994, Debris flows in the southern Coast Mountains, British Columbia: dynamic behaviour and physical properties: University of B.C. PhD thesis, $260 \mathrm{p}$.

DF 4 Wieczorek, G. F., Larsen, M. C., Eaton, L. S., Morgan, B. A., and Blair, J. L., 2001, Debris-flow and flooding hazards associated with the December 1999 storms in coastal Venezuela and strategies for mitigation: U.S. Geological Survey Open File Report 01-0144.

DF 5 Crosta, G. B., 2001, Failure and flow development of a complex slide: the 1993 Sesa landslide: Engineering Geology, v. 59, p. 173-199.

DF 6 Bovis, M. J., and Jakob, M., 2000, The July 29, 1998, debris flow and landslide dam at Capricorn Creek, Mount Meager Volcanic Complex, southern Coast Mountains, British Columbia: Canadian Journal of Earth Sciences, v. 37, p. 1321-1334.

Glancy, P. A., and Bell, J. W., 2000, Landslide-Induced Flooding at Ophir Creek, Washoe County, Western Nevada, May 30, 1983: U.S. Geological Survey Professional Paper 1617.

DF 8 Jordan, P., 1994, Debris flows in the southern Coast Mountains, British Columbia: dynamic behaviour and physical properties: University of B.C. PhD thesis, 260 p.

DF 9 Miller, H.F., 1979, Debris flows in the vicinity of Boulder, Colorado: Boulder, Colorado, University of Colorado M.S. Thesis, $93 \mathrm{p}$.

DF 10

Jordan, P., 1994, Debris flows in the southern Coast Mountains, British Columbia: dynamic behaviour and physical properties: University of B.C. PhD thesis, $260 \mathrm{p}$.

DF 11 Pierson, T. C., 1980, Erosion and Deposition by Debris Flows at Mt Thomas, North Canterbury, New Zealand: Earth Surface Processes, v. 5, p. 227-247.

DF 12 Janssen, K., and Marshall, C., 2003, unpublished report prepared for Fall 2002 Environmental Geology taught by Scott Burns, Debris flow along I-84.

DF 13

DF 14 DeGraff, J. V., 1997, Geologic Investigation of the Sourgrass Debris Flow, Calaveras Ranger District, Stanislaus National Forest: U.S. Department of Agriculture; Forest Service, FS 6200-7.

DF 15

Clague, J. J., and Evans, S. G., 1994, Formation and Failure of Natural Dams in the Canadian Cordillera: Geological Survey of Canada, Geological Survey of Canada Bulletin 464.

Jackson, E., Jr., Hungr, O., Gardner, J. S., and Mackay, C., 1989, Cathedral Mountain Debris Flows, Canada: Bulletin of the International Association of Engineering Geology, v. 40, p. 36-54.

DF 16 Jakob,M., Anderson, D., Fuller,T., Hungr,O. and Ayotte, D., 2000. An Unusually Large Debris Flow at Hummingbird Creek, Mara Lake, British Columbia. Canadian Geotechnical Journal Vol. 37, no. 5, p.1109-1125.

DF 17 Clague, J. J., and Evans, S. G., 1994, Formation and Failure of Natural Dams in the Canadian Cordillera: Geological Survey of Canada, Geological Survey of Canada Bulletin 464.

Jackson, E., Jr., Hungr, O., Gardner, J. S., and Mackay, C., 1989, Cathedral Mountain Debris Flows, Canada: Bulletin of the International Association of Engineering Geology, v. 40, p. 36-54. 
DF 18

DF 19

DF 20

DF 21

DF 22

DF 23

DF 24

DF 25

DF 26

DF 27

DF 28

DF 29

DF 30

DF 31

DF 32

DF 33

DF 34

DF 35

DF 36

Clague, J. J., and Evans, S. G., 1994, Formation and Failure of Natural Dams in the Canadian Cordillera: Geological Survey of Canada, Geological Survey of Canada Bulletin 464.

Jackson, E., Jr., Hungr, O., Gardner, J. S., and Mackay, C., 1989, Cathedral Mountain Debris Flows, Canada: Bulletin of the International Association of Engineering Geology, v. 40, p. 36-54.

Clague, J. J., and Evans, S. G., 1994, Formation and Failure of Natural Dams in the Canadian Cordillera: Geological Survey of Canada, Geological Survey of Canada Bulletin 464.

Jackson, E., Jr., Hungr, O., Gardner, J. S., and Mackay, C., 1989, Cathedral Mountain Debris Flows, Canada: Bulletin of the International Association of Engineering Geology, v. 40, p. 36-54.

Iverson, R.M., Schilling, S.P., Vallance, J.W., 1998, Objective delineation of lahar-inundation hazard zones: GSA Bulletin, vol. 100 , no. 8 , p. $972-984$.

Gallino, G. L., and Pierson, T. C., 1985, Polallie Creek debris flow and subsequent dam-break flood of 1980, East Fork Hood River basin, Oregon, U.S. Geological Survey Water-Supply Paper 2273.

Jakob, M., Hungr, O., and Thomson, B., 1997. Two debris flows with anomalously high magnitude. Debris Flow Hazards Mitigation, Mechanics, Prediction and Assessment. Procs., The First International Conference on Debris Flow Hazards ASCE, C.L.Chen, Ed.,

Jordan, P., 1994, Debris flows in the southern Coast Mountains, British Columbia: dynamic behaviour and physical properties: University of B.C. PhD thesis, 260 p.

Thurber Consultants Ltd, 1985, Debris torrent assessment, Wahleach and Floods, Highway 1, Hope to Boston Bar Creek summit, Coquihalla Highway. Report to B.C. Min. Transportation and Highways, Victoria, B.C.

Jakob, M., Hungr, O., and Thomson, B., 1997. Two debris flows with anomalously high magnitude. Debris Flow Hazards Mitigation, Mechanics, Prediction and Assessment. Procs., The First International Conference on Debris Flow Hazards ASCE, C.L.Chen, Ed., San Francisco, pp. 382-394.

Jordan, P., 1994, Debris flows in the southern Coast Mountains, British Columbia: dynamic behaviour and physical properties: University of B.C. PhD thesis, 260 p.

Jordan, P., 1994, Debris flows in the southern Coast Mountains, British Columbia: dynamic behaviour and physical properties: University of B.C. PhD thesis, 260 p.

Clague, J. J., and Evans, S. G., 1994, Formation and Failure of Natural Dams in the Canadian Cordillera: Geological Survey of Canada, Geological Survey of Canada Bulletin 464.

Jackson, E., Jr., Hungr, O., Gardner, J. S., and Mackay, C., 1989, Cathedral Mountain Debris Flows, Canada: Bulletin of the International Association of Engineering Geology, v. 40, p. 36-54.

Jordan, P., 1994, Debris flows in the southern Coast Mountains, British Columbia: dynamic behaviour and physical properties: University of B.C. PhD thesis, $260 \mathrm{p}$.

Jordan, P., 1994, Debris flows in the southern Coast Mountains, British Columbia: dynamic behaviour and physical properties: University of B.C. PhD thesis, 260 p.

Jordan, P., 1994, Debris flows in the southern Coast Mountains, British Columbia: dynamic behaviour and physical properties: University of B.C. PhD thesis, 260 p.

Thurber Consultants Ltd and Ker Priestman \& Associates Ltd, [no date], Site visit to debris torrent facilities at Charles Creek, Harvey Creek, Magnesia Creek, Alberta Creek, Lions Bay, B.C. Field Guide.

Thurber Consultants Ltd and Ker Priestman \& Associates Ltd, [no date], Site visit to debris torrent facilities at Charles Creek, Harvey Creek, Magnesia Creek, Alberta Creek, Lions Bay, B.C. Field Guide.

Curry, R.R., 1966, Observations of alpine mudflows in the Tenmile Range, Colorado: Geological Society of America Bulletin, v. 77, p. 771-776.

Jordan, P., 1994, Debris flows in the southern Coast Mountains, British Columbia: dynamic behaviour and physical properties: University of B.C. PhD thesis, 260 p.

Jordan, P., 1994, Debris flows in the southern Coast Mountains, British Columbia: dynamic behaviour and physical properties: University of B.C. PhD thesis, 260 p. 
DF 37

DF 38

DF 39

DF 40

DF 41

DF 42

DF 43

DF 44

DF 45

DF 46

DF 47

DF 48

DF 49

DF 50

DF 51

DF 52

DF 53

DF 54

DF 55

DF 56

DF 57

DF 58
Stock, J.D., 2001, unpublished data in personal communication to R.M.Iverson, 1/16/2001, Berkeley, California.

Clague, J. J., and Evans, S. G., 1994, Formation and Failure of Natural Dams in the Canadian Cordillera: Geological Survey of Canada, Geological Survey of Canada Bulletin 464.

Jackson, E., Jr., Hungr, O., Gardner, J. S., and Mackay, C., 1989, Cathedral Mountain Debris Flows, Canada: Bulletin of the International Association of Engineering Geology, v. 40, p. 36-54.

Jordan, P., 1994, Debris flows in the southern Coast Mountains, British Columbia: dynamic behaviour and physical properties: University of B.C. PhD thesis, 260 p.

Stock, J.D., 2001, unpublished data in personal communication to R.M.Iverson, 1/16/2001, Berkeley, California.

Clague, J. J., and Evans, S. G., 1994, Formation and Failure of Natural Dams in the Canadian Cordillera: Geological Survey of Canada, Geological Survey of Canada Bulletin 464.

Jackson, E., Jr., Hungr, O., Gardner, J. S., and Mackay, C., 1989, Cathedral Mountain Debris Flows, Canada: Bulletin of the International Association of Engineering Geology, v. 40, p. 36-54.

Campbell, R. H., 1975, Soil Slips, Debris Flows, and Rainstorms in the Santa Monica Mountains and Vicinity, Southern California, U.S. Geological Survey Professional Paper 851.

Jordan, P., 1994, Debris flows in the southern Coast Mountains, British Columbia: dynamic behaviour and physical properties: University of B.C. PhD thesis, 260 p.

Stock, J.D., 2001, unpublished data in personal communication to R.M.Iverson, 1/16/2001, Berkeley, California.

Jordan, P., 1994, Debris flows in the southern Coast Mountains, British Columbia: dynamic behaviour and physical properties: University of B.C. PhD thesis, 260 p.

Stock, J.D., 2001, unpublished data in personal communication to R.M.Iverson, 1/16/2001, Berkeley, California.

Walter, T., unpublished data, 1983, Memorandum: Subj: Debris slide of December 16, 1982.

Howard, T.R., Baldwin, J.E., and Donley, H.F., 1988, Landslides in Pacifica, California, caused by the storm, in Landslides, floods, and marine effects of the storm January 3-5, 1982, in the San Francisco Bay Region, California: U.S. Geological Survey Professional Paper 1434, p. 163-183.

Jordan, P., 1994, Debris flows in the southern Coast Mountains, British Columbia: dynamic behaviour and physical properties: University of B.C. PhD thesis, 260 p.

McDonnell, J.J., 1990, The effect of macropores on debris flow initiation: Quarterly Journal of Engineering Geology, vol. 23, p. 325- 332 .

Stock, J.D., 2001, unpublished data in personal communication to R.M.Iverson, 1/16/2001, Berkeley, California.

Stock, J.D., 2001, unpublished data in personal communication to R.M.Iverson, 1/16/2001, Berkeley, California.

Howard, T.R., Baldwin, J.E., and Donley, H.F., 1988, Landslides in Pacifica, California, caused by the storm, in Landslides, floods, and marine effects of the storm January 3-5, 1982, in the San Francisco Bay Region, California: U.S. Geological Survey Professional Paper 1434, p. 163-183.

Howard, T.R., Baldwin, J.E., and Donley, H.F., 1988, Landslides in Pacifica, California, caused by the storm, in Landslides, floods, and marine effects of the storm January 3-5, 1982, in the San Francisco Bay Region, California: U.S. Geological Survey Professional Paper 1434, p. 163-183.

Owens, I.F., 1972, Morphological characteristics of alpine mudflows in the Nigel Pass area, in Slaymaker, O., and McPherson, H.J., eds., Mountain Geomorphology: Vancouver, Tantalus Research, p. 93-100.

Jordan, P., 1994, Debris flows in the southern Coast Mountains, British Columbia: dynamic behaviour and physical properties: University of B.C. PhD thesis, 260 p.

Bevin, K. and E.F. Woods, 1983, Catchment geomorphology and the dynamics of runoff contributing areas: Journal of Hydrology, vol. 65 , p. 139-158.

Campbell, R. H., 1975, Soil Slips, Debris Flows, and Rainstorms in the Santa Monica Mountains and Vicinity, Southern California, U.S. Geological Survey Professional Paper 851. 
DF 59

DF 60

DF 61

DF 62

DF 63

DF 64
Stock, J.D., 2001, unpublished data in personal communication to R.M.Iverson, 1/16/2001, Berkeley, California.

Jordan, P., 1994, Debris flows in the southern Coast Mountains, British Columbia: dynamic behaviour and physical properties: University of B.C. PhD thesis, 260 p.

Owens, I.F., 1972, Morphological characteristics of alpine mudflows in the Nigel Pass area, in Slaymaker, O., and McPherson, H.J., eds., Mountain Geomorphology: Vancouver, Tantalus Research, p. 93-100.

Cannon, S.H., 1989, An approach for estimating debris flow runout distance, in Proceedings Conference XX, International Erosion Control Association, Vancouver, B.C.

Owens, I.F., 1972, Morphological characteristics of alpine mudflows in the Nigel Pass area, in Slaymaker, O., and McPherson, H.J., eds., Mountain Geomorphology: Vancouver, Tantalus Research, p. 93-100.

Major, J.J., 1996, Experimental studies of depositionby debris flows: Process, characteristics of deposits, and effects of porefluid pressure [Ph.D. dissert.]: Seattle, University of Washington, $341 \mathrm{p}$.

Iverson, R.M., 1997, The physics of debris flows: Reviews in Geophysics, v. 35, p. 245-296. 


\section{Data References for Appendix A, Rock Avalanches}

RA 1 Heim, A., 1921, Geologie der Schweiz. Band 2: die Schweizer Alpen 1. Halfte. Tauchniz Leipzig.

RA 2 Crandell, D.R., Miller, C.D., Glicken, H.X., Christiansen, R.L., and Newhall, C.G., 1984, Catastrophic debris avalanche from ancestral Mount Shasta volcano, California: Geology, vol. 12, p. 143-146.

Crandell, D.R., 1989, Gigantic debris avalanche of Pleistocene age from ancestral Mount Shasta volcano, California, and debris-avalanche hazard zonation: USGS Bulletin 1861.

RA 3 Siebert, L., Glicken, H., Tadahide, U., 1987, Volcanic hazards from Bezymianny- and Bandai- type eruptions: Bulletin of Volcanology, vol. 49, p. 435-459.

RA 4 Siebert, L., Bronto, S., Supriatman, I., Mulyana, R., 1996, Massive debris avalanche from Raung Volcano, Eastern Java: EOS, vol. 77, p. S291.

RA 5 Siebert, L., Glicken, H., Tadahide, U., 1987, Volcanic hazards from Bezymianny- and Bandai- type eruptions: Bulletin of Volcanology, vol. 49, p. 435-459.

RA 6 Haller, M J, Mendia, J E, and Ostera, H A, 1991, Mapa preliminar de riesgo en la vertiente Argentina del Volcan Peteroa; Preliminary map of risk on the Argentinian slopes of Peteroa Volcano in Proceedings for Congreso Geologico Chileno, Vina del Mar, Chile, Aug. 5-9, 1991, vol.6, pp.355-358.

RA 7 Siebert, L., Glicken, H., Tadahide, U., 1987, Volcanic hazards from Bezymianny- and Bandai- type eruptions: Bulletin of Volcanology, vol. 49, p. 435-459.

RA 8 Thiele, R., Moreno, H., Elgueta, S., Lahsen Azar, A., Rebolledo, S., Petit-Breuilh, M.E., 1998, Evolucion geologico-geomorfologica cuaternaria del tramo superior del valle del rio Laja; Quaternary geological-geomorphological evolution of the uppermost course of the Rio Laja Valley: Revista Geologica de Chile, vol.25, no.2, pp.229-253.

RA 9 Guest, N.J., Leedal, G.P., 1956, The volcanic activity of Mount Meru: Records of the Geological Survey of Tanganyika 1953, Rec., v. 3, Geological Survey of Tanganyika, Tanzania, p. 40-7.

RA 10 Siebert, L., Glicken, H., Tadahide, U., 1987, Volcanic hazards from Bezymianny- and Bandai- type eruptions: Bulletin of Volcanology, vol. 49, p. 435-459.

RA 11 Siebert, L., Glicken, H., Tadahide, U., 1987, Volcanic hazards from Bezymianny- and Bandai- type eruptions: Bulletin of Volcanology, vol. 49, p. 435-459.

Stoopes, G.R., Sheridan, M.F., 1988, Giant debris avalanches from the Colima Volcanic Complex, Mexico- Implications for long-runout landslides (>100 km) and hazard assessment: Geology, vol. 20, p. 299-302.

RA 12 Siebert, L., Glicken, H., Tadahide, U., 1987, Volcanic hazards from Bezymianny- and Bandai- type eruptions: Bulletin of Volcanology, vol. 49, p. 435-459.

RA 13 Hall, M.L., Robin, C.R., Beate, B., Mothes, P., Monzier, M., 1999, Tungurahua Volcano, Ecuador- Structure, eruptive history, and hazards: Journal of Volcanology and Geothermal Research, vol. 91, p. 1-21.

RA 14 Siebert, L., Glicken, H., Tadahide, U., 1987, Volcanic hazards from Bezymianny- and Bandai- type eruptions: Bulletin of Volcanology, vol. 49, p. 435-459.

RA 15 Omenge, J.M., Mosley, P.N., 1995, Evidence for catastrophic flank collapse of Mt. Kilimanjaro and implication for geological hazard assessment, in Proceedings of 10th Conference of the Geological Society of Africa; GSA 95 international conference, Nairobi, Kenya, Oct. 9-13, 1995, Conference Programme, vol.10, pp.99-100.

RA 16 Siebert, L., Glicken, H., Tadahide, U., 1987, Volcanic hazards from Bezymianny- and Bandai- type eruptions: Bulletin of Volcanology, vol. 49, p. 435-459.

RA 17 Cacho, L.G., Iez-Gil, J.L., Arana, V., 1994, A large volcanic debris avalanche in the Pliocene Roque Nublo Stratovolcano, Gran Canaria, Canary Islands: Journal of Volcanology and Geothermal Research, vol. 63, p. 217-229.

RA 18 Siebert, L., Glicken, H., Tadahide, U., 1987, Volcanic hazards from Bezymianny- and Bandai- type eruptions: Bulletin of Volcanology, vol. 49, p. 435-459.

RA 19 Siebert, L., Glicken, H., Tadahide, U., 1987, Volcanic hazards from Bezymianny- and Bandai- type eruptions: Bulletin of Volcanology, vol. 49, p. 435-459. 
RA 20

RA 21

RA 22

RA 23

RA 24

RA 25

RA 26

RA 27

RA 28

RA 29

RA 30

\section{RA 31}

RA 32

RA 33

RA 34

RA 35

RA 36

RA 37

RA 38

Siebe, C., Komorowski, J.C., Sheridan, M.F., 1992, Morphology and emplacement of an unusual debris avalanche deposit at Jacotitlan volcano, Central Mexico: Bulletin of Volcanology, vol. 54, p.573-589.

Arbenz, P., 1934, Helvetische Region, in ed. Schweiz Geol. Kommission, Geologischer Fuhrer der Schweiz, Wepf \& Cie, Basel.

Siebert, L., Glicken, H., Tadahide, U., 1987, Volcanic hazards from Bezymianny- and Bandai- type eruptions: Bulletin of Volcanology, vol. 49, p. 435-459.

Rowley, P.D., Kuntz, M.A., MacLeod, N.S., 1981, Pyroclastic-flow deposits: USGS Professional Paper 1250, p. 489-512.

Voight, B., Janda, R.J., Glicken, H., and Douglass, P.M., 1983, Nature and mechanics of Mount St. Helens rockslide-avalanche of 18 May 1980: Geotechnique, vol. 33, p. 243-273.

[Ampferer, 1939] compiled in Li Tianchi, 1983, A mathematical model for predicting the extent of a major rockfall: Zeitschrift fur Geomorphologi N.F., Bd. 27, heft. 24, p. 472-482.

[Lacger, 1903] compiled in Li Tianchi, 1983, A mathematical model for predicting the extent of a major rockfall: Zeitschrift fur Geomorphologi N.F., Bd. 27, heft. 24, p. 472-482.

Siebert, L., Glicken, H., Tadahide, U., 1987, Volcanic hazards from Bezymianny- and Bandai- type eruptions: Bulletin of Volcanology, vol. 49, p. 435-459.

Schuster, R.L., 2002. Usoi Landslide Dam and Lake Sarez, Pamir Mountains, Tajikistan in Proceedings for Annual Conference of Geological Society of America, Denver, Colorado, October 27-30, 2002.

Siebert, L., Glicken, H., Tadahide, U., 1987, Volcanic hazards from Bezymianny- and Bandai- type eruptions: Bulletin of Volcanology, vol. 49, p. 435-459.

Aguila, L., Newhall, C.G., Miller, C.D., and Listanco, E., unpublished document, Reconnaissance geology of a large debris avalanche from Iriga Volcano, Philippines.

Siebert, L., Glicken, H., Tadahide, U., 1987, Volcanic hazards from Bezymianny- and Bandai- type eruptions: Bulletin of Volcanology, vol. 49, p. 435-459.

Siebert, L., Glicken, H., Tadahide, U., 1987, Volcanic hazards from Bezymianny- and Bandai- type eruptions: Bulletin of Volcanology, vol. 49, p. 435-459.

Siebert, L., Glicken, H., Tadahide, U., 1987, Volcanic hazards from Bezymianny- and Bandai- type eruptions: Bulletin of Volcanology, vol. 49, p. 435-459.

Schuster, R.L., and Crandell, D.R., 1984, Catastrophic debris avalanches from volcanoes in Proceedings of the Fourth Annual Conference on Landslides, Toronto.

Kojan, E., and Hutchinson, J. N., 1978, Mayunmarca rockslide and debris flow, Peru, in Voight, B., ed., Rockslides and Avalanches: Amsterdam, Netherlands (NLD), Elsevier Sci. Publ. Co., p. 315-361.

Abele, G., 1974, Bergstürze in den Alpen: Wissenschaftliche Alpenvereinshefte 25: $230 \mathrm{~S}$.

Siebert, L., Glicken, H., Tadahide, U., 1987, Volcanic hazards from Bezymianny- and Bandai- type eruptions: Bulletin of Volcanology, vol. 49, p. 435-459.

Siebert, L., Glicken, H., Tadahide, U., 1987, Volcanic hazards from Bezymianny- and Bandai- type eruptions: Bulletin of Volcanology, vol. 49, p. 435-459.

[Turnau, 1906] compiled in Li Tianchi, 1983, A mathematical model for predicting the extent of a major rockfall: Zeitschrift fur Geomorphologi N.F., Bd. 27, heft. 24, p. 472-482.

Heim, A., 1932, Bergsturz und Menschenleben, Fretz \& Wasmuth, Zurich.

Siebert, L., Glicken, H., Tadahide, U., 1987, Volcanic hazards from Bezymianny- and Bandai- type eruptions: Bulletin of Volcanology, vol. 49, p. 435-459.

Siebert, L., Glicken, H., Tadahide, U., 1987, Volcanic hazards from Bezymianny- and Bandai- type eruptions: Bulletin of Volcanology, vol. 49, p. 435-459.

Siebert, L., 1996, Hazards of Large Volcanic Debris Avalanches and Associated Eruptive Phenomena in Monitoring and Mitigation of Volcano Hazards: Washington D.C., Springer-Verlag Berlin Heidelberg, p. 541-572. 
RA 39

RA 40

RA 41

RA 42

RA 43

RA 44

RA 45

RA 46

RA 47

RA 48

RA 49

RA 50

RA 51

RA 52

RA 53

RA 54

RA 55

RA 56

RA 57

RA 58

RA 59
[Bornhauser, 1950] compiled in Li Tianchi, 1983, A mathematical model for predicting the extent of a major rockfall: Zeitschrift fur Geomorphologi N.F., Bd. 27, heft. 24, p. 472-482.

Heim, A., 1921, Geologie der Schweiz. Band 2: die Schweizer Alpen 1. Halfte. Tauchniz Leipzig.

[Schwinner, 1912] compiled in Li Tianchi, 1983, A mathematical model for predicting the extent of a major rockfall: Zeitschrift fur Geomorphologi N.F., Bd. 27, heft. 24, p. 472-482.

Siebert, L., Glicken, H., Tadahide, U., 1987, Volcanic hazards from Bezymianny- and Bandai- type eruptions: Bulletin of Volcanology, vol. 49, p. 435-459.

Siebert, L., Beget, J.E., Glicken, H., 1995, The 1883 and late-prehistoric eruptions of Augustine volcano, Alaska: Journal of Volcanology and Geothermal Research, vol. 66, p. 367-395.

Siebert, L., Glicken, H., Tadahide, U., 1987, Volcanic hazards from Bezymianny- and Bandai- type eruptions: Bulletin of Volcanology, vol. 49, p. 435-459.

Siebert, L., Glicken, H., Tadahide, U., 1987, Volcanic hazards from Bezymianny- and Bandai- type eruptions: Bulletin of Volcanology, vol. 49, p. 435-459.

Voight, B., and Pariseau, W.G., 1978, Rockslides and avalanches, an introduction in Rockslides and Avalanches, 1, B. Voight, ed., Elsevier Publishing Company, p. 2-63.

[Trevisan, 1941] compiled in Li Tianchi, 1983, A mathematical model for predicting the extent of a major rockfall: Zeitschrift fur Geomorphologi N.F., Bd. 27, heft. 24, p. 472-482.

[Arbenz, 1934] compiled in Li Tianchi, 1983, A mathematical model for predicting the extent of a major rockfall: Zeitschrift fur Geomorphologi N.F., Bd. 27, heft. 24, p. 472-482.

[Schwinner, 1912] compiled in Li Tianchi, 1983, A mathematical model for predicting the extent of a major rockfall: Zeitschrift fur Geomorphologi N.F., Bd. 27, heft. 24, p. 472-482.

Abele, G., 1974, Bergstürze in den Alpen: Wissenschaftliche Alpenvereinshefte 25: $230 \mathrm{~S}$.

Siebert, L., Glicken, H., Tadahide, U., 1987, Volcanic hazards from Bezymianny- and Bandai- type eruptions: Bulletin of Volcanology, vol. 49, p. 435-459.

Till, A., 1907, Das Naturereignis von 1348 und die Bergsturze des Dobratsh, Mitteilungen du K.K. Geographischen Gesellschaft in Wein 50 Wein.

Siebert, L., Glicken, H., Tadahide, U., 1987, Volcanic hazards from Bezymianny- and Bandai- type eruptions: Bulletin of Volcanology, vol. 49, p. 435-459.

Siebert, L., Glicken, H., Tadahide, U., 1987, Volcanic hazards from Bezymianny- and Bandai- type eruptions: Bulletin of Volcanology, vol. 49, p. 435-459.

Siebert, L., Glicken, H., Tadahide, U., 1987, Volcanic hazards from Bezymianny- and Bandai- type eruptions: Bulletin of Volcanology, vol. 49, p. 435-459.

Siebert, L., Beget, J.E., Glicken, H., 1995, The 1883 and late-prehistoric eruptions of Augustine volcano, Alaska: Journal of Volcanology and Geothermal Research, vol. 66, p. 367-395.

Muller, L., 1964, The rock slide in the Vaiont Valley: Felsmechanik und Ingenieur-geologie, vol. 2, p. 148-212.

[Schwinner, 1912] compiled in Li Tianchi, 1983, A mathematical model for predicting the extent of a major rockfall: Zeitschrift fur Geomorphologi N.F., Bd. 27, heft. 24, p. 472-482.

Evans, S.G., and Brooks, G.R., 1991, Prehistoric debris avalanches from Mount Cayley volcano, British Columbia: Canadian Journal of Earth Science, vol. 28, no. 9, p.xxx.

Siebert, L., Glicken, H., Tadahide, U., 1987, Volcanic hazards from Bezymianny- and Bandai- type eruptions: Bulletin of Volcanology, vol. 49, p. 435-459.

Ramsey, D.W., Robinson, J.E., Dartnell, P., Bacon, C.R., Gardner, J.V., Mayer, L.A., Buktenica, M.W., 2002, Crater Lake revealed; Using GIS to visualize and analyze postcaldera volcanoes beneath Crater Lake, Oregon: U.S. Geological Survey Geologic Investigations Series I-2790. 
RA 60

RA 61

RA 62

RA 63

RA 64

RA 65

RA 66

RA 67

RA 68

RA 69

RA 70

RA 71

RA 72

RA 73

RA 74

RA 75

RA 76

RA 77

RA 78

RA 79

RA 80

RA 81

RA 82

RA 83

Heuberger, H., 1968, Die Alpengletscher im Spat und Postglazial: Eine chronologische Ubersicht, Eiszeitalter und Gegenwart, vol. 19, p. 270-275 Ohringen (Hohenlohe'sche Buchhandl).

[Turrer, 1962] compiled in Li Tianchi, 1983, A mathematical model for predicting the extent of a major rockfall: Zeitschrift fur Geomorphologi N.F., Bd. 27, heft. 24, p. 472-482.

[Bruckner, 1901] compiled in Li Tianchi, 1983, A mathematical model for predicting the extent of a major rockfall: Zeitschrift fur Geomorphologi N.F., Bd. 27, heft. 24, p. 472-482.

[Aichinger, 1951] compiled in Li Tianchi, 1983, A mathematical model for predicting the extent of a major rockfall: Zeitschrift fur Geomorphologi N.F., Bd. 27, heft. 24, p. 472-482.

[Schwinner, 1912] compiled in Li Tianchi, 1983, A mathematical model for predicting the extent of a major rockfall: Zeitschrift fur Geomorphologi N.F., Bd. 27, heft. 24, p. 472-482.

Heim, A., 1932, Bergsturz und Menschenleben, Fretz \& Wasmuth, Zurich.

Gignoux, M., and Barbier, R., 1955, Geologie des barrages et des amenagements hydrauliques: Masson et Cie, Paris, 343 pp.

Siebert, L., Glicken, H., Tadahide, U., 1987, Volcanic hazards from Bezymianny- and Bandai- type eruptions: Bulletin of Volcanology, vol. 49, p. 435-459.

Naranjo, J.A., Young, S.R., Moreno, H., 1998, Mitigation of volcanic risk in the Biobio River basin, Chile in Proceedings for Cities on volcanoes, International meeting on Cities on volcanoes, Rome and Naples, Italy, June 28-July 4, 1998.

Siebert, L., Glicken, H., Tadahide, U., 1987, Volcanic hazards from Bezymianny- and Bandai- type eruptions: Bulletin of Volcanology, vol. 49, p. 435-459.

Siebert, L., Beget, J.E., Glicken, H., 1995, The 1883 and late-prehistoric eruptions of Augustine volcano, Alaska: Journal of Volcanology and Geothermal Research, vol. 66, p. 367-395.

[Bruckner, 1901] compiled in Li Tianchi, 1983, A mathematical model for predicting the extent of a major rockfall: Zeitschrift fur Geomorphologi N.F., Bd. 27, heft. 24, p. 472-482.

Siebert, L., Glicken, H., Tadahide, U., 1987, Volcanic hazards from Bezymianny- and Bandai- type eruptions: Bulletin of Volcanology, vol. 49, p. 435-459.

Heim, A., 1932, Bergsturz und Menschenleben, Fretz \& Wasmuth, Zurich.

Gignoux, M., and Barbier, R., 1955, Geologie des barrages et des amenagements hydrauliques: Masson et Cie, Paris, 343 pp.

Plafker, G. and Erickssen, G.E., 1978, Nevados Huascaran Avalanches, Peru in Rockslides and Avalanches, 1, B. Voight, ed., Elsevier Publishing Company, p.277-314.

Abele, G., 1974, Bergstürze in den Alpen: Wissenschaftliche Alpenvereinshefte 25: 230 S.

Heim, A., 1921, Geologie der Schweiz. Band 2: die Schweizer Alpen 1. Halfte. Tauchniz Leipzig.

[Hammer, 1927] compiled in Li Tianchi, 1983, A mathematical model for predicting the extent of a major rockfall: Zeitschrift fur Geomorphologi N.F., Bd. 27, heft. 24, p. 472-482.

Naranjo, J.A., and Francis, P., High velocity debris avalanche at Lastarria volcano in the north Chilean Andes: Bulletin of Volcanology, vol. 49, p. 509-514.

Voight, B., and Pariseau, W.G., 1978, Rockslides and avalanches, an introduction in Rockslides and Avalanches, 1, B. Voight, ed., Elsevier Publishing Company, p. 2-63.

Klebelsberg, R., 1935, Geologie von Tirol.- 872 S., 1 Kt., 11 Beil.; Berlin (Borntraeger)[Leidlmair, 1956] compiled in Li Tianchi, 1983, A mathematical model for predicting the extent of a major rockfall: Zeitschrift fur Geomorphologi N.F., Bd. 27, heft. 24, p. 472-482.

[Leidlmair, 1956] compiled in Li Tianchi, 1983, A mathematical model for predicting the extent of a major rockfall: Zeitschrift fur Geomorphologi N.F., Bd. 27, heft. 24, p. 472-482.

Gignoux, M., and Barbier, R., 1955, Geologie des barrages et des amenagements hydrauliques: Masson et Cie, Paris, 343 pp.

[Pashinger, 1953] compiled in Li Tianchi, 1983, A mathematical model for predicting the extent of a major rockfall: Zeitschrift fur Geomorphologi N.F., Bd. 27, heft. 24, p. 472-482. 
RA 84

RA 85

RA 86

RA 87

RA 88

RA 89

RA 90

RA 91

RA 92

RA 93

RA 94

RA 95

RA 96

RA 97

RA 98

RA 99

RA 100

RA 101

RA 102

RA 103

RA 104

RA 105
Inokuchi, T., 1985, The Ontake Rock Slide and Debris Avalanche Caused by the Naganoken-Seibu Earthquake in Proceedings IVth International Conference and Field Workshop on Landslides, Tokyo, 10 p.

Nagaoka, Masatoshi, 1987, Geomorphological Characteristics and Causal Factors of the 1984 Ontake Landslide Caused by the Naganoken-Seibu Earthquake: Bulletin of the Geographical Survey Institute, vol. 31, p. 72-89.

Hancox, G.T., Chin, T.J., and McSaveney, M.J., 1991, Immediate report, Mt. Cook Rock Avalanche, 14 December 1991, Report by the New Zealand Department of Scientific and Industrial Research, 23 December 1991.

Siebert, L., Glicken, H., Tadahide, U., 1987, Volcanic hazards from Bezymianny- and Bandai- type eruptions: Bulletin of Volcanology, vol. 49, p. 435-459.

Fuganti, A., and V.G. Antonio, 1969, Previsioni sul progettato traforo ferroviario del Brennero in base studio geologico del tracciato: Convegno Int. sui problemi tecnini nella costruzione di gallerie, Torino, 1969.

[Broili, 1914] compiled in Li Tianchi, 1983, A mathematical model for predicting the extent of a major rockfall: Zeitschrift fur Geomorphologi N.F., Bd. 27, heft. 24, p. 472-482.

Heim, A., 1932, Bergsturz und Menschenleben, Fretz \& Wasmuth, Zurich.

Hadley, J.B., 1978, Madison Canyon Rockslide, Montana, USA in Rockslides and Avalanches, 1, B. Voight, ed., Elsevier Publishing Company, p. 167-180.

[Grasso, 1968] compiled in Li Tianchi, 1983, A mathematical model for predicting the extent of a major rockfall: Zeitschrift fur Geomorphologi N.F., Bd. 27, heft. 24, p. 472-482.

Furrer, E., 1962, Der Bergsturz von Bormio: Vierteljahrsschrift der Naturforschenden Gesellschaft in Zürich, vol. 107, p. 233-242.

Voight, B., and Pariseau, W.G., 1978, Rockslides and avalanches, an introduction in Rockslides and Avalanches, 1, B. Voight, ed., Elsevier Publishing Company, p. 2-63.

Ramsey, D.W., Robinson, J.E., Dartnell, P., Bacon, C.R., Gardner, J.V., Mayer, L.A., Buktenica, M.W., 2002, Crater Lake revealed; Using GIS to visualize and analyze postcaldera volcanoes beneath Crater Lake, Oregon: U.S. Geological Survey Geologic Investigations Series I-2790.

Heim, A., 1932, Bergsturz und Menschenleben, Fretz \& Wasmuth, Zurich.

Ramsey, D.W., Robinson, J.E., Dartnell, P., Bacon, C.R., Gardner, J.V., Mayer, L.A., Buktenica, M.W., 2002, Crater Lake revealed; Using GIS to visualize and analyze postcaldera volcanoes beneath Crater Lake, Oregon: U.S. Geological Survey Geologic Investigations Series I-2790.

[Bruckner, 1901] compiled in Li Tianchi, 1983, A mathematical model for predicting the extent of a major rockfall: Zeitschrift fur Geomorphologi N.F., Bd. 27, heft. 24, p. 472-482.

Till, A., 1907, Das Naturereignis von 1348 und die Bergsturze des Dobratsh, Mitteilungen du K.K. Geographischen Gesellschaft in Wein 50 Wein.

Heim, A., 1932, Bergsturz und Menschenleben, Fretz \& Wasmuth, Zurich.

[Penck, 1901] compiled in Li Tianchi, 1983, A mathematical model for predicting the extent of a major rockfall: Zeitschrift fur Geomorphologi N.F., Bd. 27, heft. 24, p. 472-482.

Cruden, D.M. and O. Hungr, 1986, The debris of Frank Slide and theories of rockslide-avalanche mobility: Can. J. Earth Science, vol. 23, 425-432.

Heuberger, H., 1966, Gletschergeschichtliche Untersuchungen in den Zentralalpen zwischen Sellrain und Ötztal: Wissenschaftliche Alpenvereinshefte, heft 20,126 pp.

Blair, T.C., 1999, Form facies and depositional history of the North Long John rock avalanche, Owens Valley, California: Canadian Journal of Earth Science, vol. 36, p. 855-870.

Montandon, F., 1933, Chronologie des grands eboulements alpins, du debut de l'ere chretienne a nos jours, in Materiaux pour l'Etude des Calamites, Societe de Geographie Geneve, vol. 32, p. 271-340.

[Onde, 1938] compiled in Li Tianchi, 1983, A mathematical model for predicting the extent of a major rockfall: Zeitschrift fur Geomorphologi N.F., Bd. 27, heft. 24, p. 472-482. 
RA 106 [Klebelsberg, 1935] compiled in Li Tianchi, 1983, A mathematical model for predicting the extent of a major rockfall: Zeitschrift fur Geomorphologi N.F., Bd. 27, heft. 24, p. 472-482.

RA 107 Montandon, F., 1933, Chronologie des grands eboulements alpins, du debut de l'ere chretienne a nos jours, in Materiaux pour l'Etude des Calamites, Societe de Geographie Geneve, vol. 32, p. 271-340.

RA 108 [Cornelius, 1936] compiled in Li Tianchi, 1983, A mathematical model for predicting the extent of a major rockfall: Zeitschrift fur Geomorphologi N.F., Bd. 27, heft. 24, p. 472-482.

RA 109 [Schwinner, 1912] compiled in Li Tianchi, 1983, A mathematical model for predicting the extent of a major rockfall: Zeitschrift fur Geomorphologi N.F., Bd. 27, heft. 24, p. 472-482.

RA 110 [Cadisch, 1953] compiled in Li Tianchi, 1983, A mathematical model for predicting the extent of a major rockfall: Zeitschrift fur Geomorphologi N.F., Bd. 27, heft. 24, p. 472-482.

RA 111 [Bourdier, 1961] compiled in Li Tianchi, 1983, A mathematical model for predicting the extent of a major rockfall: Zeitschrift fur Geomorphologi N.F., Bd. 27, heft. 24, p. 472-482.

RA 112 Plafker, G. and Erickssen, G.E., 1978, Nevados Huascaran Avalanches, Peru in Rockslides and Avalanches, 1, B. Voight, ed., Elsevier Publishing Company, p.277-314.

RA 113 [Jackli, 1957] compiled in Li Tianchi, 1983, A mathematical model for predicting the extent of a major rockfall: Zeitschrift fur Geomorphologi N.F., Bd. 27, heft. 24, p. 472-482.

RA 114 Montandon, F., 1933, Chronologie des grands eboulements alpins, du debut de l'ere chretienne a nos jours, in Materiaux pour l'Etude des Calamites, Societe de Geographie Geneve, vol. 32, p. 271-340.

RA 115 Heim, A., 1932, Bergsturz und Menschenleben, Fretz \& Wasmuth, Zurich.

RA 116 Ramsey, D.W., Robinson, J.E., Dartnell, P., Bacon, C.R., Gardner, J.V., Mayer, L.A., Buktenica, M.W., 2002, Crater Lake revealed; Using GIS to visualize and analyze postcaldera volcanoes beneath Crater Lake, Oregon: U.S. Geological Survey Geologic Investigations Series I-2790.

RA 117 [Gillitzer, 1912] compiled in Li Tianchi, 1983, A mathematical model for predicting the extent of a major rockfall: Zeitschrift fur Geomorphologi N.F., Bd. 27, heft. 24, p. 472-482.

RA 118 Ramsey, D.W., Robinson, J.E., Dartnell, P., Bacon, C.R., Gardner, J.V., Mayer, L.A., Buktenica, M.W., 2002, Crater Lake revealed; Using GIS to visualize and analyze postcaldera volcanoes beneath Crater Lake, Oregon: U.S. Geological Survey Geologic Investigations Series I-2790.

RA 119 McSaveney, M.J., Sherman Glacier Rock Avalanche, Alaska, USA in Rockslides and Avalanches, 1, B. Voight, ed., Elsevier Publishing Company, p. 197-258.

RA 120 [Jackli, 1957] compiled in Li Tianchi, 1983, A mathematical model for predicting the extent of a major rockfall: Zeitschrift fur Geomorphologi N.F., Bd. 27, heft. 24, p. 472-482.

RA 121 Crandell, D.W, and Fahnestock, R.K, 1965, Rockfalls and avalanches from Little Tahoma Peak on Mount Rainier Washington: Geological Survey Bulletin 1221-A, Washington, 30 p.

RA 122 Evans, S.G., and Clague, J.J., 1998, Rock avalanche from Mount Munday, Waddington Range, British Columbia, Canada: Landslide News, no. 11, p. 23-25.

RA 123 Heim, A., 1932, Bergsturz und Menschenleben, Fretz \& Wasmuth, Zurich.

RA 124 [Schwinner, 1912] compiled in Li Tianchi, 1983, A mathematical model for predicting the extent of a major rockfall: Zeitschrift fur Geomorphologi N.F., Bd. 27, heft. 24, p. 472-482.

RA 125 [Schwinner, 1912] compiled in Li Tianchi, 1983, A mathematical model for predicting the extent of a major rockfall: Zeitschrift fur Geomorphologi N.F., Bd. 27, heft. 24, p. 472-482.

RA 126 [Schmit-Thome, 1960] compiled in Li Tianchi, 1983, A mathematical model for predicting the extent of a major rockfall: Zeitschrift fur Geomorphologi N.F., Bd. 27, heft. 24, p. 472-482.

RA 127 Evans, S.G., Aitken, J.D., Wetmiller, R.J., and Horner, R.B., 1987, A rock avalanche triggered by the October 1985 North Nahanni earthquake, District of Mackenzie, N.W.T.: Canadian Journal of Earth Science, vol. 24, p. 179-184. 
RA 128 [Schwinner, 1912] compiled in Li Tianchi, 1983, A mathematical model for predicting the extent of a major rockfall: Zeitschrift fur Geomorphologi N.F., Bd. 27, heft. 24, p. 472-482.

RA 129 Abele, G., 1974, Bergstürze in den Alpen: Wissenschaftliche Alpenvereinshefte 25: 230 S.

RA 130 Clague, J.J., and Souther, J.G., 1983, The Dusty Creek landslide on Mount Cayley, British Columbia: Canadian Journal of Earth Science, vol. 19, p. 524-539.

RA 131 Voight, B., and Pariseau, W.G., 1978, Rockslides and avalanches, an introduction in Rockslides and Avalanches, 1, B. Voight, ed., Elsevier Publishing Company, p. 2-63.

RA 132

Voight, B., and Pariseau, W.G., 1978, Rockslides and avalanches, an introduction in Rockslides and Avalanches, 1, B. Voight, ed., Elsevier Publishing Company, p. 2-63.

RA 133 Abele, G., 1974, Bergstürze in den Alpen: Wissenschaftliche Alpenvereinshefte 25: 230 S.

RA $134 \quad$ Vallance, J.W., 1999, Postglacial lahars and potential hazards in the White Salmon River system on the southwest flank of Mount Adams, Washington: USGS Bulletin No. 2161.

RA 135 Abele, G., 1974, Bergstürze in den Alpen: Wissenschaftliche Alpenvereinshefte 25: $230 \mathrm{~S}$.

RA 136 Iverson, R.M., written communication, August 1997: fieldnotes.

RA 137 Ramsey, D.W., Robinson, J.E., Dartnell, P., Bacon, C.R., Gardner, J.V., Mayer, L.A., Buktenica, M.W., 2002, Crater Lake revealed; Using GIS to visualize and analyze postcaldera volcanoes beneath Crater Lake, Oregon: U.S. Geological Survey Geologic Investigations Series I-2790.

RA 138 Hoyer, M., 1971, Puget Peak Avalanche, Alaska: Geological Society of America Bulletin, vol. 82, p. 1267-1284.

RA 139 Jakob, M., 2008, unpublished data in personal communication to J.W. Vallance, 20 June 2008, Vancouver, British Columbia, Canada.

RA 140 Jakob, M., 2008, unpublished data in personal communication to J.W. Vallance, 20 June 2008, Vancouver, British Columbia, Canada.

RA 141 [Niederer, 1941] compiled in Li Tianchi, 1983, A mathematical model for predicting the extent of a major rockfall: Zeitschrift fur Geomorphologi N.F., Bd. 27, heft. 24, p. 472-482.

RA 142 Heim, A., 1932, Bergsturz und Menschenleben, Fretz \& Wasmuth, Zurich.

RA 143 [Jackli, 1957] compiled in Li Tianchi, 1983, A mathematical model for predicting the extent of a major rockfall: Zeitschrift fur Geomorphologi N.F., Bd. 27, heft. 24, p. 472-482. 


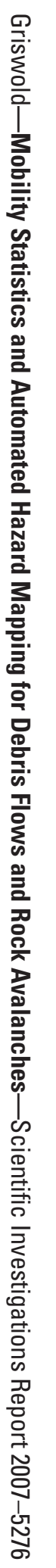

